\title{
NÁO CIRCULA
}

GEOLOGIA DA REGI DOO DE MAIRIPORÃ, S.

REINHOLT ELLART

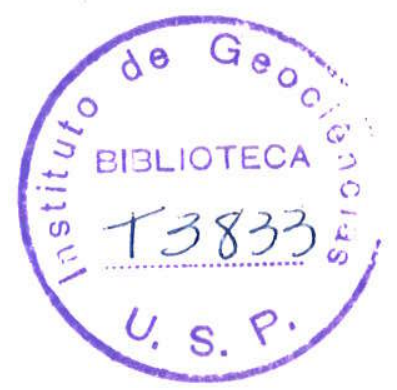

TENE APRESENTLEA LO CONCURSO DE LIVRE DOCERAA DA CADIIRA DE GEOLOGIA, D... FCULDADE DE BILOSOTIA, CIMUCIAS E IITRAS DA UNIVRRSIDADE DE SẼO PAULO

1964

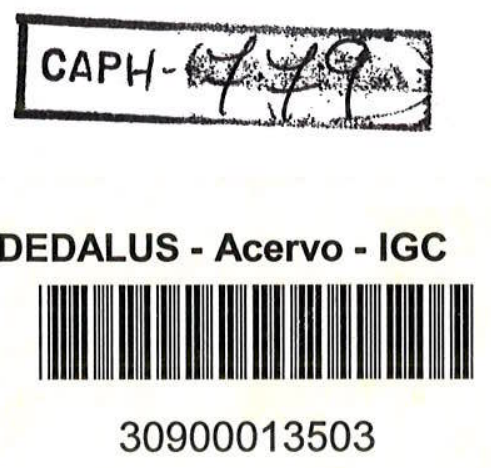


e-Composig̃o dos granitos ..........44 4. PEGMATTTOS

a. Turmalina granitos e pegmatitos turmaIinfferos .................. 46

b. Pegmatitos esplitos .............4 48

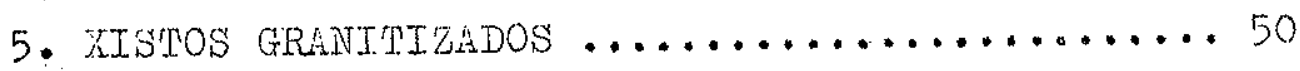
6. HORNPELS

a. Hornfels Peliticos ............. 54

b. Hornfels Psamticos ............ 55

c. Zonas de xisto no granito Cantareira. 55

d. Biotita Hornfels ............... 56

e. Hornfels Célcio-silicatado ........ 57

VII - TECTNITCA

1. VIETODOS E STIVBLOGIA ................ 59

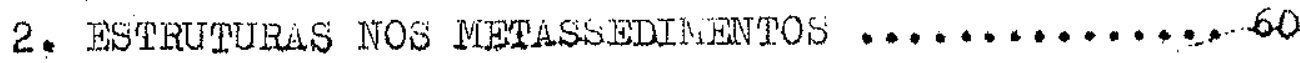

3. ESTTRUTURAS ITOS GR 2 ITTOS

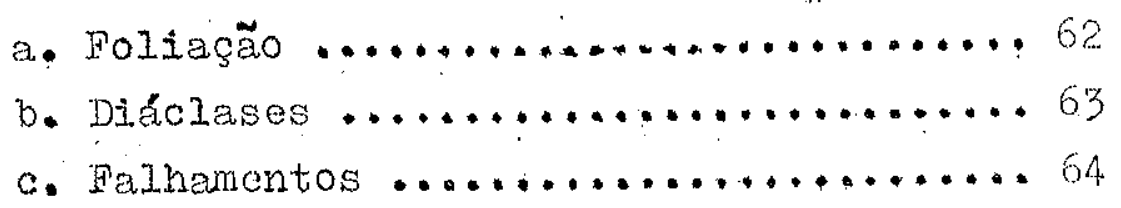

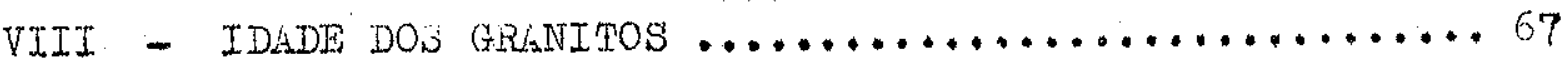

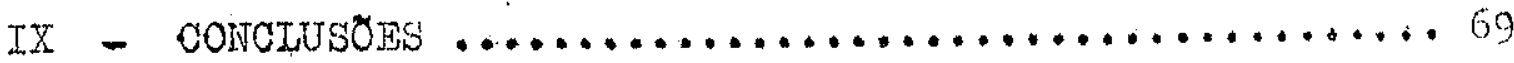

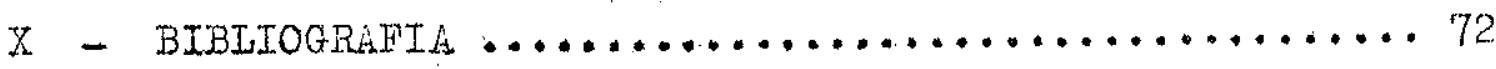

$-\operatorname{xxx} \S \mathrm{xxx}-$

Ilustrą̧ões

16 Tiguras

8 Fotografias

11 Wicrofotografias

3 Tabelas

Mapa Geológico com 2 perfis

$-\operatorname{xxx} \$ \mathrm{XxX}-$ 


\section{$x-$ RTSUNO}

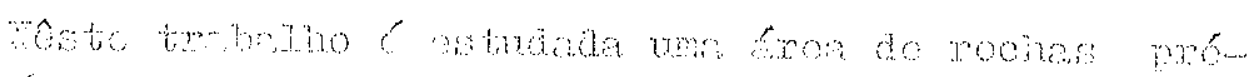

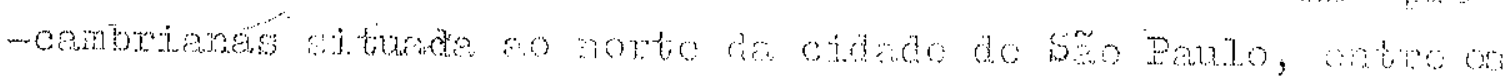

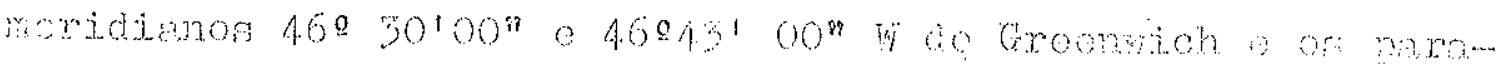

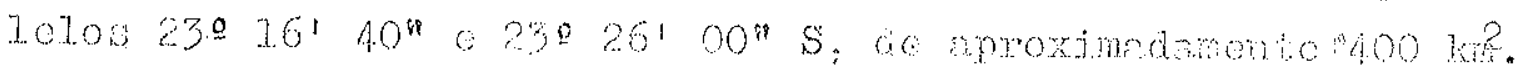

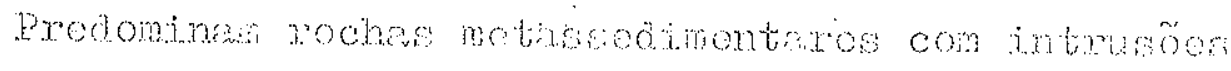
srattion, gue formen tros oomos atstintos.

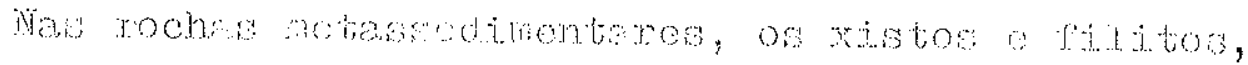

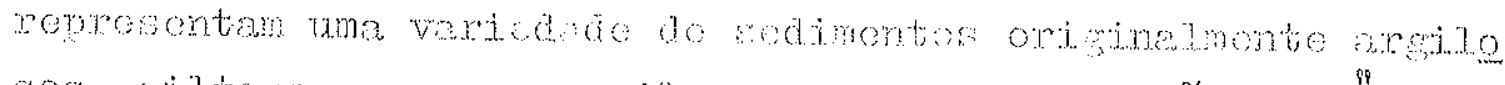

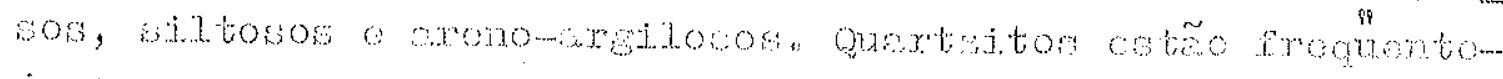

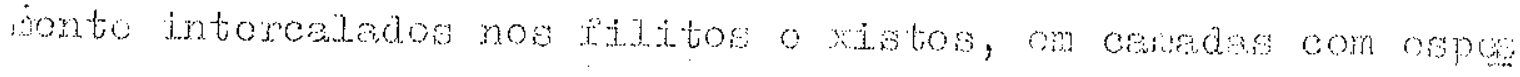

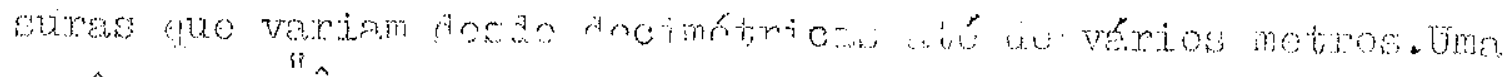

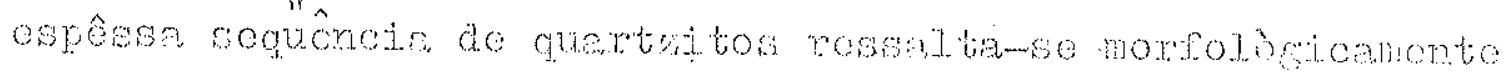

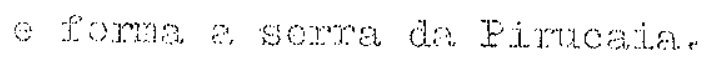

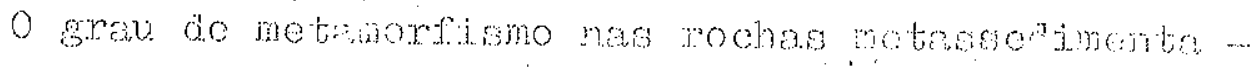
ros amonts nas proximidedos dos prentios o w pomanom froas or ristos form granjtirados.

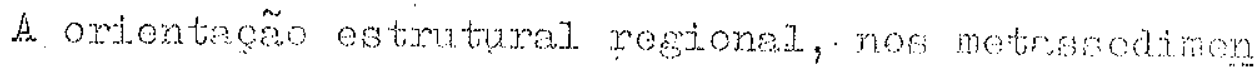

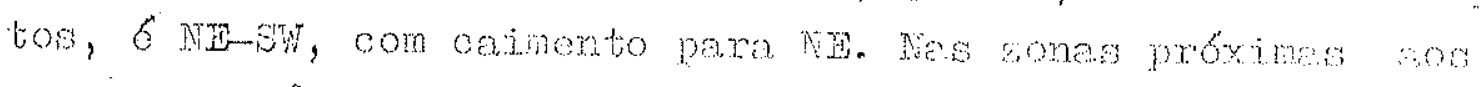

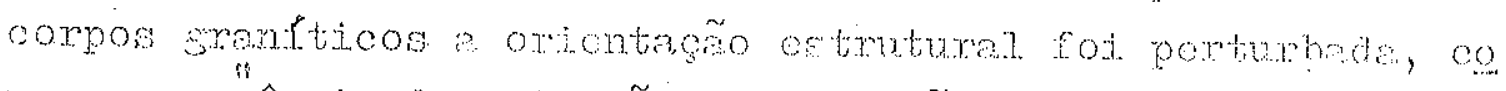

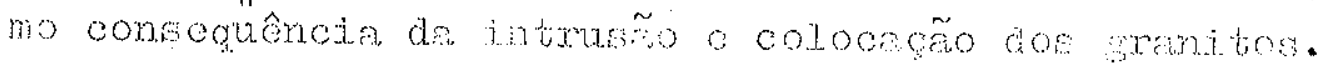

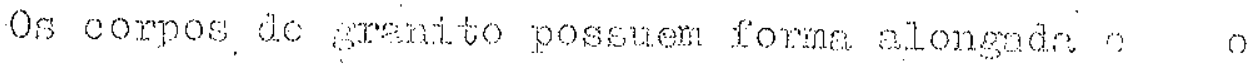

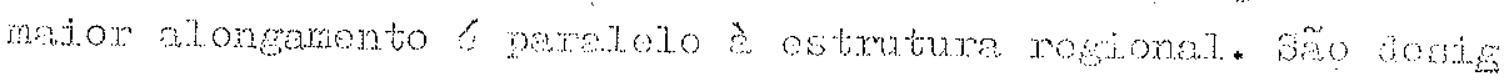

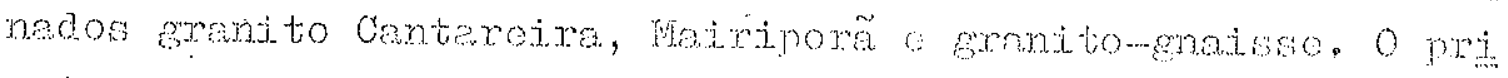
notro forma maior parto da somra dantaroina, o somoo

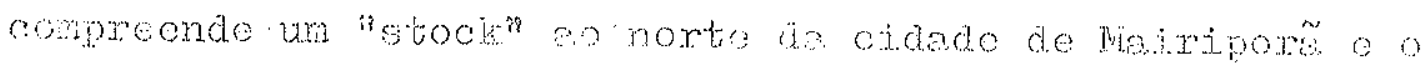

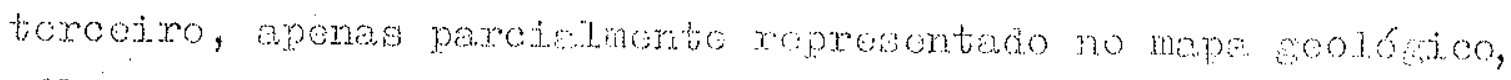

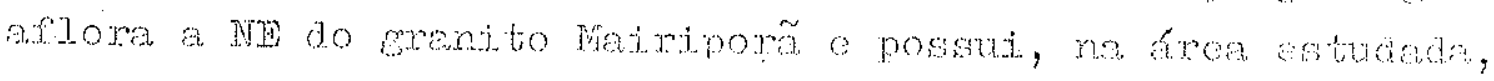

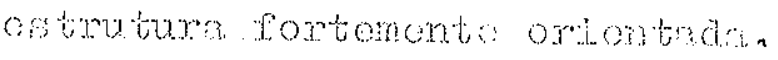

Apres nom ammancie de biotita porfiroblastos do microctrnio, te veson, contimetricos o microolinio for

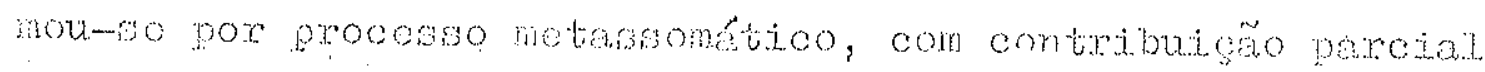

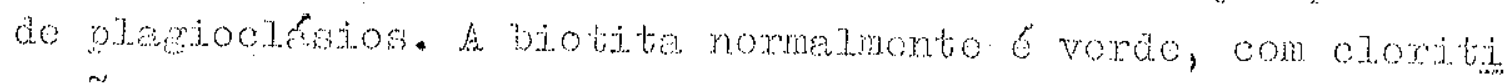

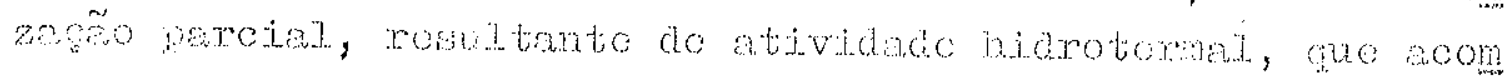


penhor a feno metursométicon.

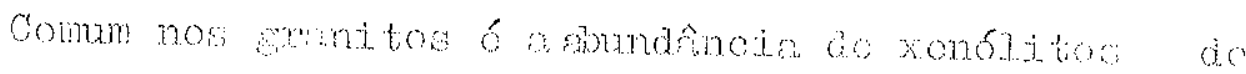

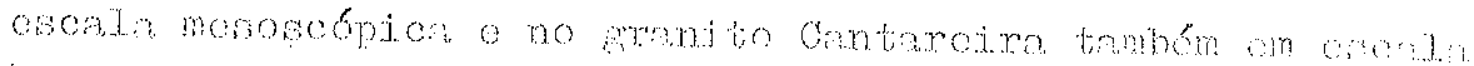

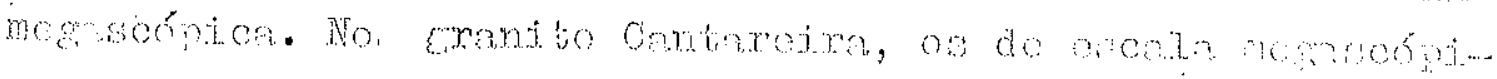

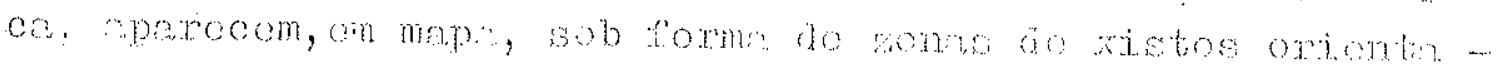

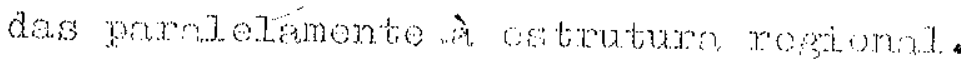

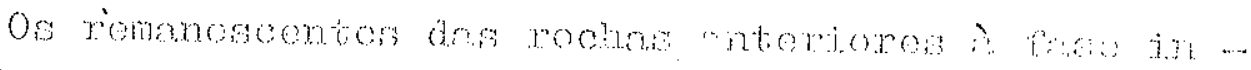

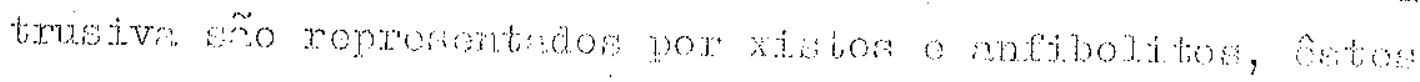

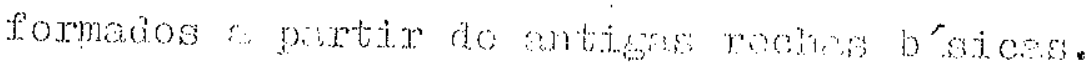

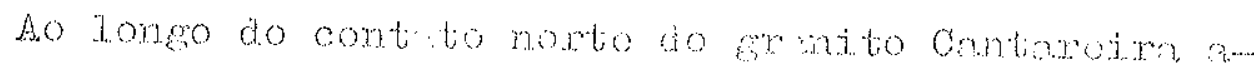

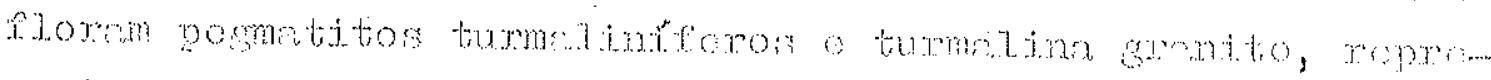

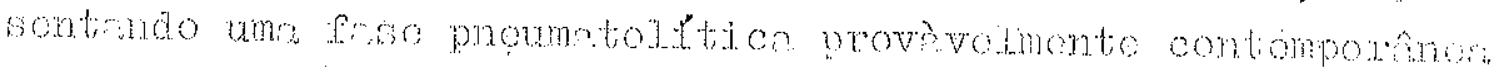
aे foso notessomática.

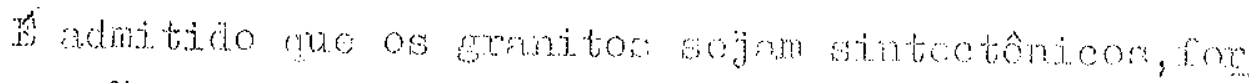

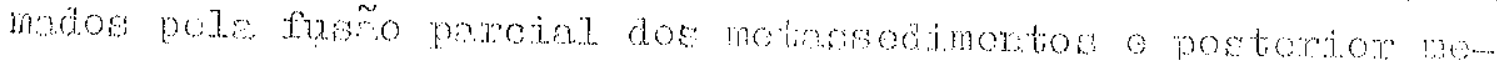
taseomatismo.

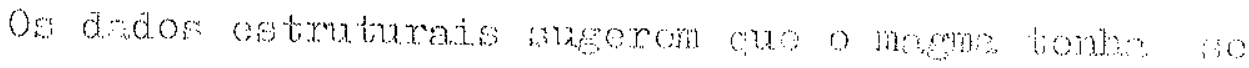

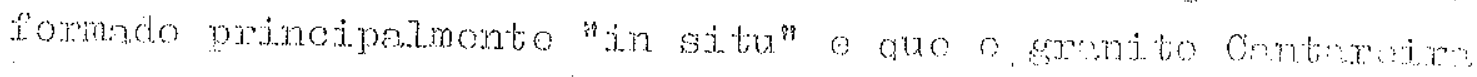
roprosonta porgão suporior do butbrito.

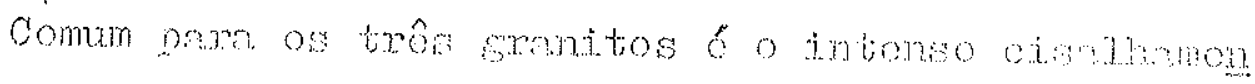
to dos minoxis da roch, gue se acentum nos rome teminate dos comos intrusiros.

Detomingonos do idade, pelo mótodo $\mathrm{K} / \mathrm{Ar}$, rando-

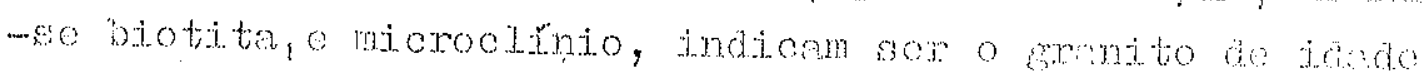
pré-combriens suporior. 


\section{II - INTRODUCFQ}

Nos metrssedimentos pre-crmbrimos superiores do ths tado de săo Paulo ocorrem grandes corpos intrusivos, orientados no seu maior comprimento paralelemente à estrutura regionel.

Estas intrusões, constituidzs principalmente de gra nttos o granodioritos, apresentam entre si grandes semelhancas, tanto estruturatis como texturais.

W objeto do presente trabalho anelisar numa ́xea li mitada, as relaçōes entre rochas metassedimentares e intrusiTes, na esperança de que os dados apresentados contribuam com um subsldio ao conhecimento da evolução geolósica do Pre-Camoriamo Superior, no Estado de São Paulo.

A area estudada, de aproximedamente $400 \mathrm{~km}^{2}$, situa-se ao norte da cidade de São Faulo, aproximadamente entre os meriatinos $46^{\circ} 30^{\prime}$ 00" e $46^{\circ} 43^{\prime} 00^{\prime \prime} \mathrm{W}$ de Greenwich e os para 2eles $23^{\circ} 16^{\prime} 40^{\prime \prime}$ e $23^{\circ} 26^{\prime} 00^{n} \mathrm{~s}$ (fig. n. L).

Para o levantamento geol.6gico foram usadas fotografla aéreas na escala de $1: 12.000$ e para e parte sul, mapas topogreficos ne escala de 1:10.000, da Prefeitura Municipal de. São Puulo, edição de 1959.

Us dados de campo foram depois compiliados no mapa, na esoale de $\lambda: 40.000$, baseado no mosaico aerofotogréfico, exequtado para o Instituto Geográfico e Geológico do Eistado de Selo Daulo. 
No rilanco sul da serra da contareira, coberto por dense regetação, os cminhos são escassos, de modo yue os prolongamentos des zonas de xistos, no grenito, foram muitas vêes inferidos.

No estudo peirogrécico foram feitas ancitses modais dos granitos e anfibolitos, usando-se o contador de pontos ("point counter"). Pare cada lamina foram conbados em média 1.000 a. 1.500 pontos.

\section{$-\operatorname{xxx} 8983 \oint x \times x-$}

0 autor expressa os sinceros agradecimentos ao Prof. Dr. Francis J. Turner, da Universidade da Callérnis, Berkew ley, pelos conselnos ados e visita de brea estudada. hos Profs. Drs. John T. Sterk o Noman Herz, ds U.S. Geologieal Sugvey, pelas sugestöes apresentadas. Ao Prof. Dr. José M. V. Coutinino, de Cadejra de Petrologia, ds paculdade de Filosoria, Ciências e Jetras, U.S.P. , pelos auxílios na interpretaço pe trogrérica. Ao Erof. Dr. Rut Ribeiro Branco, da mesma Cadeira,

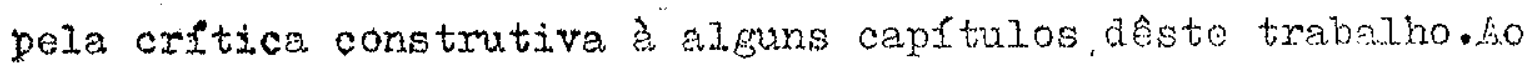
Dx. Faustino Penalva pelas microfotografias.

Ao Prof. Dr. Viktor Weinz, Wiretor do Departamento de Geologia e Peleontologie, de riculade de Filosofie, Ciências e Ietress, U.S.P., a gratidão pelo estrmulo, orientação a cxitica. 


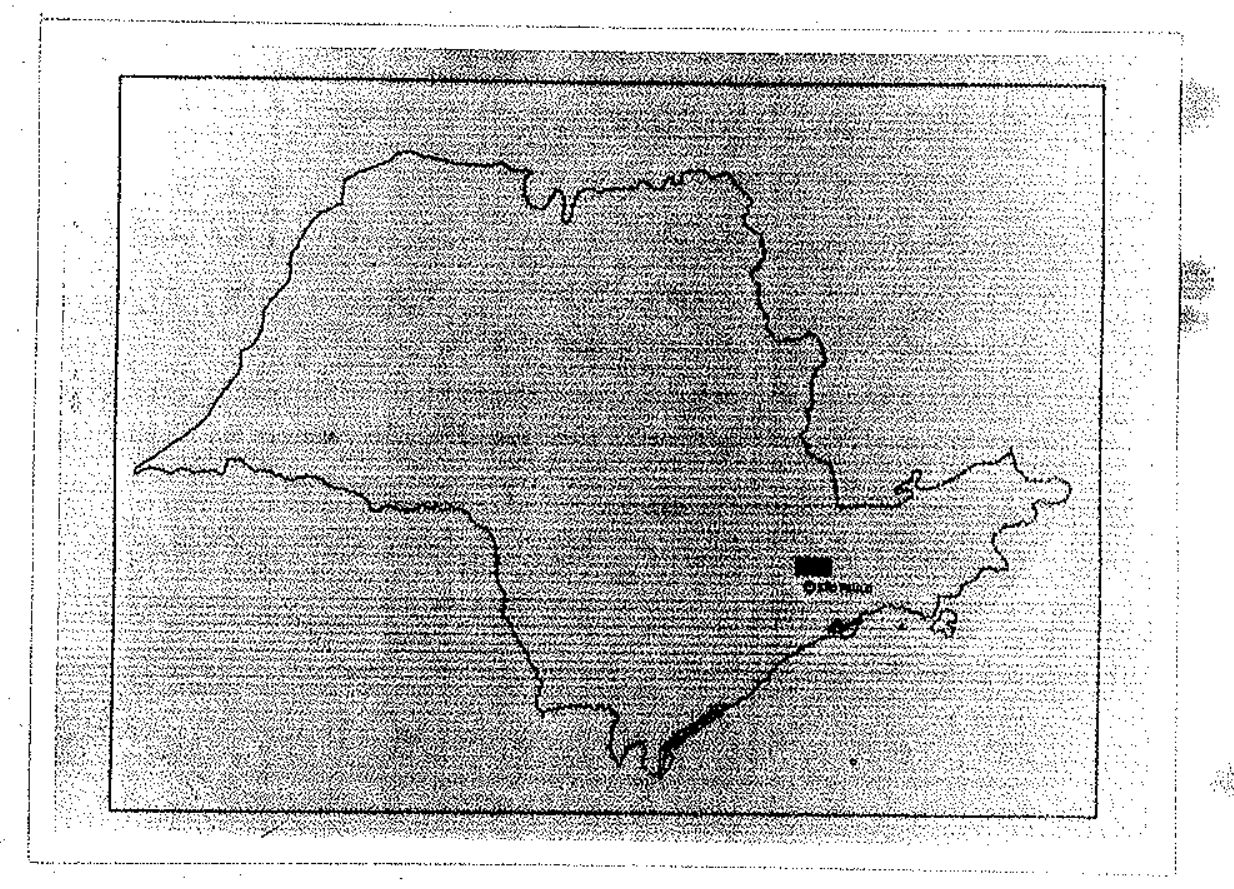

Mg. no 1 - Locallzaçöo goográfica da área 


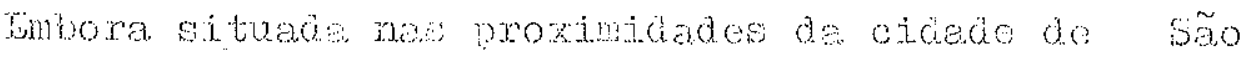

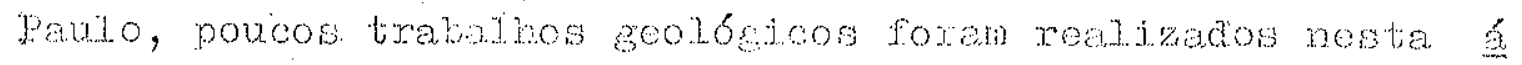
red.

ierece destague o prinejmo loventanento soolónco,

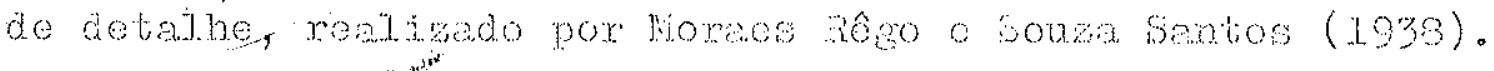

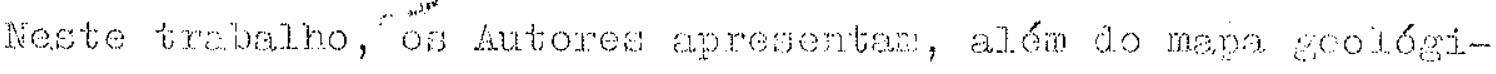

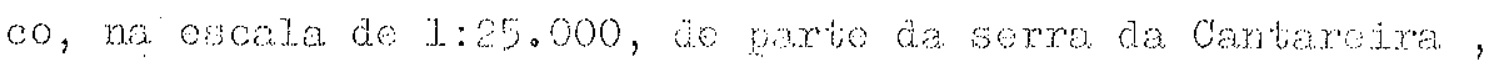
no municípto de são Palo, une dencriço de solosta e tooto

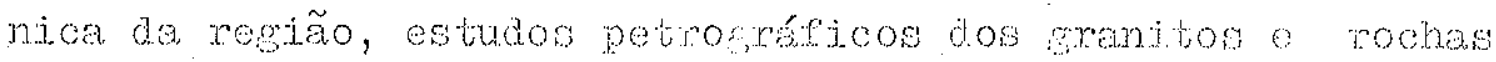
associadas, alem da análise de propriededos tocnolónicas pos mititios.

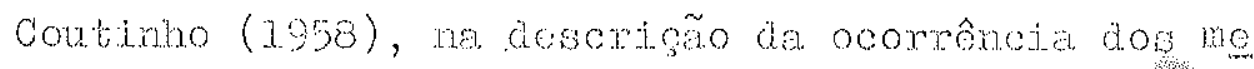
taconglomerados vue aftoram na altuwas do $\mathrm{km} 10$ da via nlignguera, dedicou ntergão ao estua petrografico e senétioo dos metassedimertos ascocjacos aos metaconglomerados, axibo Iitos e do srantito "Hirituba", que é une continuagáo do era mito da serra da Cantareira.

As relagóes existentes entre a tectonica a serra da Centareira e origem da bacia sedjmentar de são paulo fo ram discritidas por Almeja (1955). Para êtie Autor, a gênese

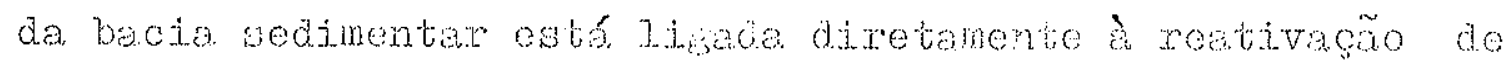
antigas falhas, de rejeito directonat, nos grantos da serra da Cantareira, orientadas paralelamente dे estrutura resional.

Procensos petrologicos, resultantes da aço do me tanowfino termal, na sexte wa Roque, foram descritos por Franco (1959). Noste trabatho o Antor descreve, entre outros,

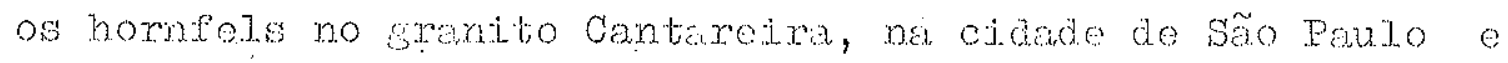
na crea de Perus.

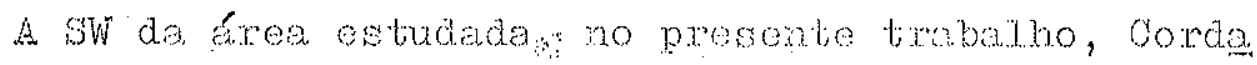
ni ot al. (2961) estuderan a geologia na resia do Jaxagre om 1962 descreverm as relasós perromeoloficas de rochas cklciomilicatadas, con on granitos e rochas encaxantes, na regiäo de perus.

Ainda nesta região, os pegratios turmatinforos, que ocorrem junto ao granito da serra da Gantareira, froram 
estudades por Wessui (.1963).

As ocorrencias de anfibolitos, no resiz̃o do Jara gua, foram objeto de pesquisas petrol6gicas por Gomes (1962). Ste futor, baseando-se em dados de campo e petrolbicos, con fimmou a jubtese emitida por coutinho (1955), de que os cor pos de anfibolitos foram oriminados por metarorismo aframotermel a partir de artiges rochas bésicas. 


\section{PRTS-OMURTANO TNITRIOR}

As relaçós e os contatos do Pré-Carbriano Inferior com as rochas da série São Rovue ainda não são conhectaos. - Pré-Cambriano Infexior, en contato com o Pré-Cambriano Su perior, está delünitado na follha Geologica de Jundiat, do Instituto Geográfico e Geolbaico do listedo de são paulu, (vo hlers et.a1.1954) apenas como gnáisse Arqueoźico, seguindo uma linha irregular, de direção $\mathrm{H}$ - w um pouco ao norto da á rea ora estudada.

As rochas típicas da série são Rogue afloram ma via Fernão Dias até ò $\mathrm{km} 528$, com orientação geral Wis- Da. Do $\mathrm{km}$ 529 para norte afloram snáisses migmatiticos, com a mesma o rientaça dos filitos e xistos. São consituidos de zonas gnálissicas leucocráticas alternadas con faixas xicas em bio tita ou camadas quartifiticas, cortades por pegmetitos.

Mos mignatitos säo erequentes dobras de arrasto que mostrain srande variaça no cainento do eixo. ram mesmo ejxo, destas dobras de arrastojt o caimento varia de 00 a $90^{\circ}$, em poucos metros, sem apresentar cisalhamento ou fendas de ten são. A variação dos eixos das dobras de arrast o. 6 aponas no caimento dentro do plano axial, indjcando grande plesticidade da rocha er condições de forte pressão dirigida. Os aigma tijos são cortados por zonas pegnatójdes irregulares, formadas por substituição metassomática, onde estão presentes tra ços da estrutura original representados por minerais escuros.

o contato direto entre os injematitos e as rochas -consideradas cono Pré-Cambriano superior ainda não foi obser: vado em nenhum lugar desta ćrea. Afloramentos razoáveis des tas rochas acham-se, na área do contato, distanciados quase sempre de um quilômetro ou ineis. A djeção estrutural é mais ou menos concordante, variando apenss a jntensidade do trau. de metamorfismo, que é major naquelas supostamente pextencen tes a uma fase anterior deposiç̃o da sequência metassedi mentar da serie são roqué. 
A berie são Rogue, denominacão atribuida a Gonzaga de Campos, (Oliveira e Ieonardos, 1943) constituj no patado de são Paulo a continuaça da série trungùi, do Paraná.

Aflora en larga faixa, parale labente à costa e constituida, principalmente, de metassedinentos peljticos com intrusoes acidas, que ocupam mijhares de guilonetros qua drados.

Pretassedimentos de origen guímjca, calcários o doLomitos, afloram, en majores áreas, no sul do Estrado de são Faulo, aparecendo en mapa sob foma de lentes, às vếres, de mujtos quilômetros de extenção, intercaladas em metassedimen tos pelíticos. Mas proximidades de são Paulo, calcários e do lowitos, afloram en zonas restritas e de área ben menor.

A onientação estrutural das rockas netassedinenta-

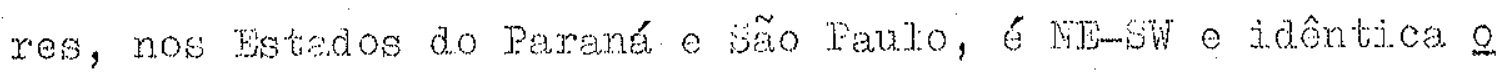
rientạão observa-se no alinhemento dos corpos intrusivos écidos.

Das rochas intrusivas cidas, as de nator expressão, em área, tormam o chamado granito "Eiribuba" ou "olho de sam po". Contribuições para o comecimento da geologia e petro grafia dos granitos "Pirj.tuba" foram apresentadas por vérios Autores. Para a parte sul do gotado de Bão Eaulo, devein ser. mencionados os trabalhos de Leonardos (1934), Guimarẽes (1936, 1937) e Barbosa (1941) e, para as áreas proximas a são Paulo, os de 'Guimarães $(1936,1937)$, Woraes Rểo e soura Santos (1938), Continho (1953, 1955), Franco (1958) e Condani et a1. (1961). - brau de metanorfismo, nas rochas metassedimentares, no Mstado de são taulo, aiminui da costa para o interj-

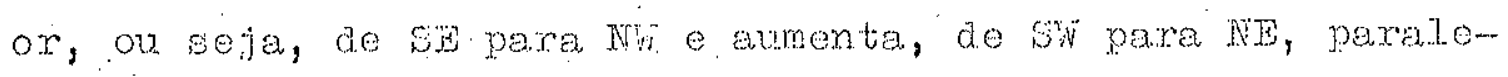
lamente à estmutura regional.

Vérios autores (oliveira e Leonardos, 1943, Almeida, $195 \%$ e HIert, 1961) referem-se ao metamorfismo de grau mais elevado (biotita-gnáisses), nas proximidades do litoral e maís baixo pera o interior (ijlitos). Já em 1.934, tueonardos aventou a hipótese de terem os esforcos tectônicos, durante a orosenese, se dirigido de ș para NH, determinando o alinha- 


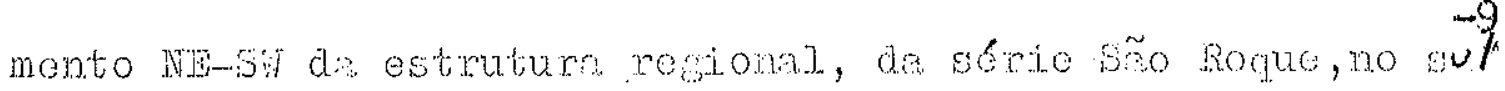
do wetno de são Pulo.

Mre bres ortudada, as rochas do Pró-Crmbriano Supe rior, anterjores nos rrotos, so constituidas principanon to do fizjtos o xistos. Fetos prodominum nas zones proximas .os contetos o o amento do motemorismo dovo onter. aigado

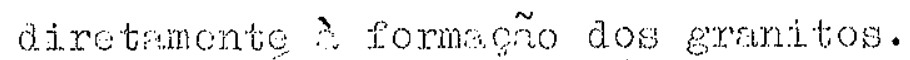

Restritos a pequenes sress ocorrom rochns metrssom

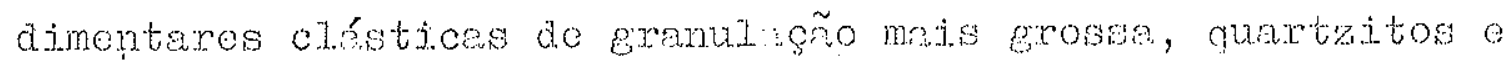
corglomerados o roches carbonatades impuras.

A. E da Erea reprosentad no mepe geolóico os rochas metassedinertares possuen caratrerseticas de metamorfis mo mais elevedo e prodominam xistos o biotita-gnéissea.

Nos granitos e encoixontes aflorm feimes do anfi-m boljtos, de composję̃o minoral e estrutura, on goral, bastan

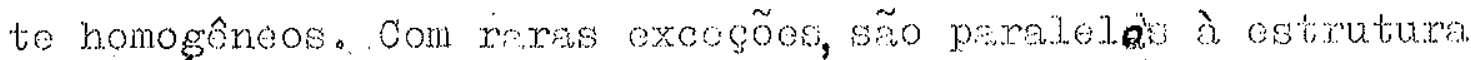
regiomal $\theta$ as espessures observadas variom dosdo poucos motros ate al gumes contonas de motros.

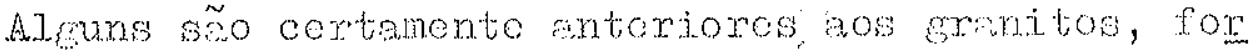

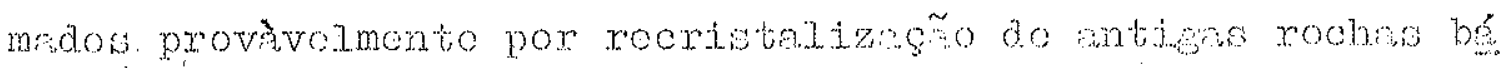
sicas, reprosontando antigos diquos ou stils.

A descrigá dos vírios tipos de rowne, prosonta-

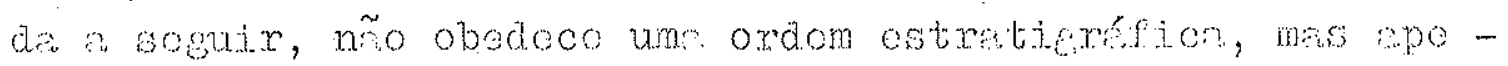

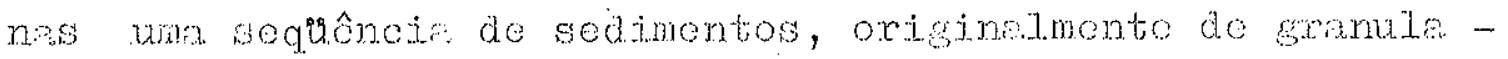
ç̃̃o grossa para os do gramileño fine.

$\therefore$. Hotaconglomerados

Apenses em tros zones foram observados delendos to tos de motnconglomexados, intercelidos em xistos e filitos, nêo individueinedos no mepe geologjeo.

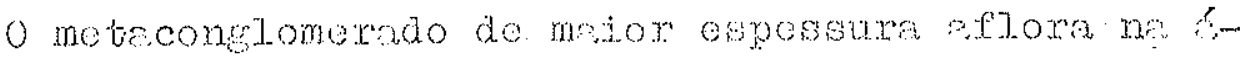

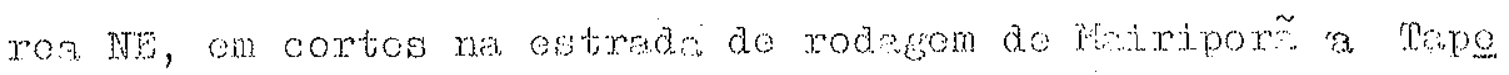

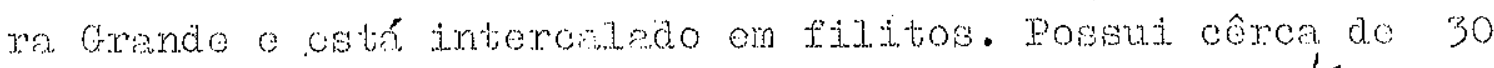

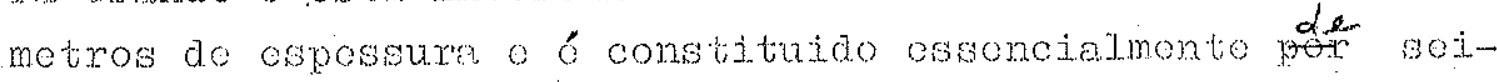
xos de quartzito a ranjto, onde os maioxes podom altrapes ser $20 \mathrm{~cm}$ de comprinonto, mbotidos om matriz de filito seri. ótico rico on grasos do qurtoo. o volumo de motriz igunte 
ou supere à ocupd polos seixos, que estro deromados, col.

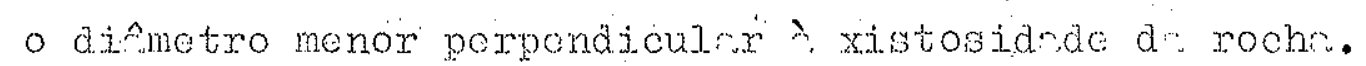

A scounds ocomrôncin Ioonizn-so mum corto dr vin Fomño Dins, $\mathrm{km} 554$, onde ontre xistos ruttrmdos intercnlam so uma dolgndn cmads de motaconglomorndos, de poucos metros de cspossura. Trmbom af os constituintes clésticos majoros sr̃o do quertzito e gronjto, que estão defomados è possuem apenas poucos centímetrós de diâmetro.

Ne sxon Nh, nas proximidras do contrto norte do gruito Mairiporn, ocorro ume frixn na qual os xistos onglo. bem blocos de quartzito, de vérios decímotros. liveste sren, não se trate do um conglomorado vordadeiro, mas do blocos do guentzito esprasos nos xistos.

b. Qunrtzitos.

Interchlades on xistos e filitos ocorrom camans quertzíticas do espessura verifrol. Comumonto sño cumedns do poucos decímotros nte ajguns metros do ospessurs. Em geral o commonto of bem preservado e, hs verzos, os quertzitos ostro om nitomancia com dolgados loitos do com das origins imonto argilosas ou sílticas.

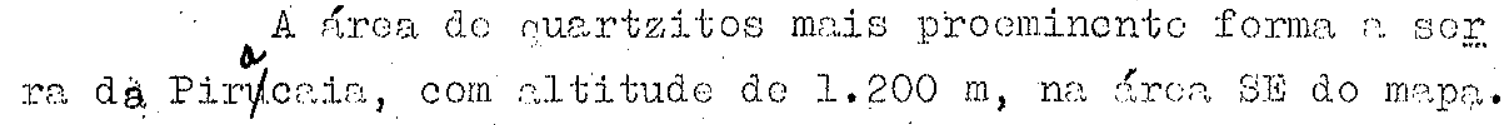
Possui.forma lonticular, com comprimonto de pouco mais do 9 $\mathrm{km}$ : e largure méxima inforior a $2 \mathrm{~km}$. Astes qurtaitos, com intorcnlacoos de crmadas do xistos, sño do gramulagro hoterogenos e om zonas de maior ciselhemonto sofroram rocristalizrigno intensa, destrendo-so frngmontos do quntzo, hs vê zes, contimétricos. No contrito wos quartzitos com os xis

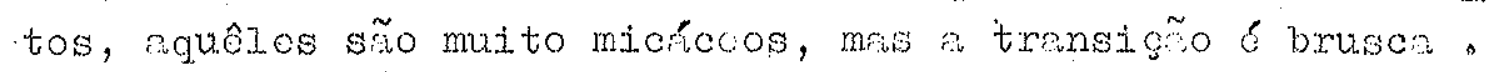

Esta lonte do quartzitos, que no prete sul possuit

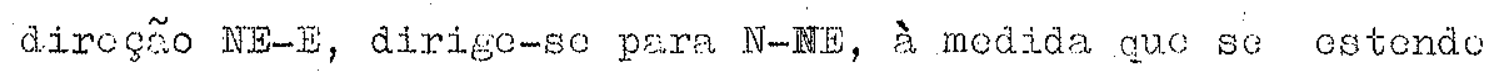
pera.norte, acomparhando o contrto com o granito Cantaroira. No Jardim Hortolandia, nss proximidndos do contato com o granito, o quartzito 6 cortado por alguns pegmetitos altomalos, do poucos decímotros do ospossura. 
c. Xistos e Filitos.

Sño as rochns motamórficas prodominntos ne resiano o constituom tôda veriedado de rochos metrssodimontaros originadas de sedimentos areilosos, arenomreilosos, stuticoso arcosianos.

Aflormentog do rochas froscas sĩo escassos e om goral o manto do intempoxismo é ospôsso. A ostratificrer̃o original dos sodimentos ostá bom consorvada, principalmonto nos metsssiltitos o metaarcóstos o frequentomento nos filitos altorados.

Im algumas excas, os filitos aprosotam estretiticegro ritmica, na qual se repotom comedas milimetricas de materind originalmonte ergiloso" com outras origjnalmonte mais siliticas. Em lemine delgrade, notr-so quo sc sucodom estretos formados de grânuos do quartzo o outros com prodominência -. de sericita e clorjta, que crosconam peralelamente aos plenos de acamamento. Xistos o filitos altermmo, froqüento mente, com comades do moterial originalmente síltico, arcosi. ano ou mosmo arenosio.

Esta nIternêncta de estratos argilosos com cumadas portencontes fraç̃o mais grossa é bem veribvel, dosdo ostratos milimetricos até de aloumas dezenas do notros. Jim al gins eflormontos a passagem do xistos a filitos b mis ou menos brusca. Os xistos, no goral, prodominam nas proximidades dos contritos com os granitos.

A dircção rogiona dos xistos e filitos ह N.s-sW , constante em exeas afastadas dos granitos, enquato que nos. proximiades dos coxpos intrusivos a oriontaço é varíńvel. Formarn dobxes asejmétricas, com oixos de pequeno eejinento, no goral para NT. Dontro do granito da serra da Contareira, não s6 mas proximidados do contnto, como tamber na parte contral, xistos foram prosorvados o estão ortentados paralolamonto $n$ folingão do granito sofrondo; localmonto, motamoreismo mais elovado.

o graid do metamorfismo mais baixo, obscrvedo on amostras do filitos, corresponde a freios "xisto vordos", re presontada por filitos, normanento afnstados dos contatos com 
3. grantos. Nas proximidades dêtes, as rochas pellticas ow

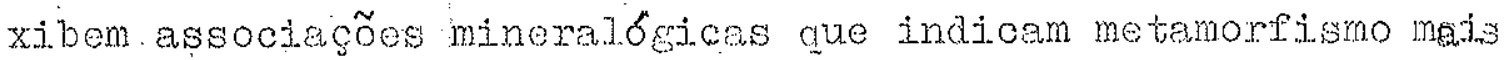
elevado. Os biotita xistos são os mais comus a formados prin cipalmente por biotita, muscovita e quartzo. Localnente ocox re estaurolita, em porfiroblastos, com alterą̧o para muscovita. Nos xitros, a E de Mairiporä, afloxa uma camada de vém rios metros de espessura, Pormeda de turmalina xisto, Este xjsto 6 constituido essencialmente de tumalina e quartzo e pequena quantidade de muscovita, bjotita e granada os pris mas de turmalina, con alinhamento sub-paralelo a xistosidade, possuem pleocroismo acentuado: E(vermelho rosado) e o (verme Iho escuro).

\section{d. Anfibolitos}

Nos metassedimentos e no granito da serra da Canta reira efloram anfibolitos, formando corpos tabulares, com espessuras que variam de poucos ate conteras de metros.

No geral ontão isoxientados con os xistos e fili tos e quando dentro do granito, orientamse paralelanente à folizça dêste.

Mineraldgicamente são constituidos essencialmente de homblonda, plagiocí́sio, quertzo e como acessbrios possu en titanita, titanomagnetita ou ilmenita. Os minerais securderios meis comuns são: eploto, clorita, leucoxenio e celei ta.

A hornblenda of o constituinte minerelogico mats abundente e de dues variedades distintas.

A primeira, mais frequente nos enfibolitos dentro das rochas metassedimentares; e uma hornblenda verde pálida; de pleocroismo fraco; $\mathrm{X}$ (amerelo esverdeado) e Z (verde claro); ânguto $2 \mathrm{~V}$ grande e frequentenente gemjnada. As vêzes, 6 zonada e nas bordas a côr verde b mais intensa. Forma cris tais xenomorfos ou porfiroblastos; que poaem atingir $2 \mathrm{~mm}$ de comprimento, de contôno suturado, numa matriz de pequenos grãos de quartzo plagioclásjos.

Na homblonda são comuns inclusões de quantro; opa cos e, tas vêres, pequenos cristais de enfib́l.jo do mesmo tipo: A altexaço mais comam é para opíato e a menos frequento para clorite: Nos oxistais najores, não raro; os planos 
de clivagem foram ourvados.

A segunda variedade de homblenda 6 comm nos anfi bolitos conservados dentro do granito da serra da Canterejre.

Ocorre sob forma de cristais hipjdiomorfos ou porm firoblastos, que podem ultrepessar 3 min de comprimento. A côr. E de tons mais intensos, com pleocroismo $X$ (amerelo osverdea do), $\underline{Y}$ (verde escuro) e $\underline{\underline{Z}}$ (verde azulado), $\underline{z} / \mathrm{c}=162$ e 0 ângulo $2 \mathrm{~V}$ menor que nas hormblendas do tipo anterior.

As vềes, 6 crivada de numerosas inclusós do quant zo. A alteração para epldoto e clorita é menos conspicua que no caso anterior. (fotomicrografia $n, 10$ )

Os plagioclásios são melhor conservados nos anfibo litos dentro do granito. A forma é geralmente hipidiomorta, quase sempre estão Ifmpidos ou com sericitizacão incipiente. A geninaço mítipla ef a mais frequente, seguindo-se a segu do a Lei do Periclínio. A composição varia de An-30 a An-45.

Im aiguns anfjbolitos a titanomagnetita (?) है um ncessbrio abundante. Geralmente inclusa ne hormblenda e rodeada de uma aurbola de grânulos de leucoxonio, çue passe a

\section{titanita.}

Ira tabela abaixo e dada a composição nodal do 7 arnostras de anfibolitos.

TABEIA II

\begin{tabular}{|l|r|r|r|r|r|r|r|}
\hline amostra ne & 1 & 2 & 3 & 4 & 5 & 6 & 7 \\
horrblenda & 69,0 & 55,5 & $55, Q$ & $70, Q$ & $62, Q$ & 65,0 & $70, Q$ \\
plagioclásio & 16,6 & 30,0 & $40, Q$ & $23, Q$ & $29, Q$ & 19,8 & $25, \varphi$ \\
guartzo & 12,6 & 11,0 & 4,0 & $5, Q$ & $6, Q$ & 3,5 & $4, Q$ \\
acessórios & 1,8 & 3,5 & $1, Q$ & $2, Q$ & $3, Q$ & 11,7 & $1, Q$ \\
\hline
\end{tabular}

Composigão hodal de anfibolitos

(em porcentagem volume)

amostras 1 a 5 - anfibolitos no granito da serra da Cantareira

amostras 6 e 7 - anfibolitos nos metassedimentos 
Coutinho. (1955) e Gomes (1962) consideram os anfi bolitos que afloram a w da área ora em aprêço, como sendo or riginados pela reoristalização de antigas rochas básicas.

o autor concorda com a opinião dos Autores acima mencionados, admitindo que os anfibolitos representam diques ou silis na sequência metassedimentar.

São anteriores não sర́ aos granitos, mas também anteriores ou contemporineos ao dobramento regional, uma vếr que o Iineamento, representado pela orientação dos prismas de hornblenda, 6 paralelo ao lineamento nos metassedimentos. $\mathrm{Na}$ altura do $\mathrm{km} 538$ da via Fernão Dias, um afloraw mento de anfibolito, dentro do granito, possui comprimento su perior a $100 \mathrm{~m}$. Forma pequeno anticlinal e a orientação dos prismas de hornblenda imprime à rocha 6timo Iineamento, para lelo ao caimento do eixo do anticlinal.

$\mathrm{Na}$ parte central do anfibolito, aparentenente não afetado metassomàticamente, o plagioclásio é hipiaiomorfo e $11 m p i d o$. Geralmente apresenta pequeno zoneamento, mais sbdico nas bordas que no nucleo, de composigão An-40.

No contato com o granito, evidenciando a preexistên cia do anfibolito, são nútidos os sineis de metamoriismo de conteto e metassomatismo.

Desenvolvem-se porfiroblastos de plagioclásio que englobam quartzo e homblenda. Ao longo dos planos de clivagem do anfibb1jo forma-se biotita, com pleocroismor $\mathrm{X}$ (amare10 palha) e $z$ (castanho avermelhado), rodeado de leucoxênio ou com inclusoes de acículas de mutilio.

No estágio seguinte a biotita torna-se verde e pas sa a clorita e eplato. Ieucoxênio dé origem grânulos de titarita. Dentro dos plagioclésios formam-se pequenos grânulos de epldoto e serioita. O microcínio, xenomorfo e poiquiloblástico, engloba os minerais anteriores, substitui o plam gioclásio sericitizado.

Porfiroblastos de plagioclásio, formados pelo meta morfismo de contato, também" sẽo substituidos por microclínio (microfotografia n. 11). 


\section{GRANITOS}

No mapa geológico são demarcados três corpos intry sivọ principais, de grande extensão em área, que cortam as rochas metassedimentares. São designados simplesmente granitos, no sentido amplo, como sugerido por Chayes (1957), para rochas plutônicas maciças ou fracamente orientadas, com teores de quartzo de 20 a $40 \%$ do volume. Pelas proporçóes en tre plagiocilsio e feldspato potássico predominam rochas dos tipos granodiorito e adamellito (fig. n. 2).

o corpo granftico de maior extensão, em área, já foi delimitado parcialmente e descrito por Moraes Rêgo e Souza Santos (1938), que the deram vários nomes locais, de acôrdo com particulaxidades texturais e mineralbgicas. Neste trabalho será designado simplesmente, granito Cantareira e ocupa a maior parte da serra da Cantareira.

Area bem menor 6 ocupada pelo "stock" granftico que aflora do norte do rio Juquert, no muniolpio de Mairiporã e em pequena área W do municlpio de Franco da Rocha. Apresenta semelhança textural e mineral6gica com o granito Cantareira e será chamado granito Mairiporã, municlpio no qual êste ocupa a sua maior area. o terceiro corpo granftico aflora apenas en pequena parte na região estudada e ocorre a NE do granito Mairipo 
rñ. Possuj forma do cunhn e na fron estudada exibe ostrutura diforonte da dos outros dois granitos. E fortemente orientado, prralelamento k̀ estrutura regional. A oxient çóo exibida pe 10 granito deve-se a esforgos tectônicos que o cisalharam e o milonitizaram, imprimindo s rocha, a primeira vista, aspec to gnáissico. Pela sur estrutura fortemonte orientada sork denominado granito-gnéisse.

Associadrs ao granito Cantaroira ocorrem nas proxi midrades dos contetos pequenas injeços granticas, com folia ção bem nitida e pequenas zonas de xistos granitizados.

a. Granito Cantrireira.

- granito Cantareira ocupa a mior parte da serra da Cantaroira, formanao batolito alongado, com diroção NE-SW. Na hirea estudadn a Iargura móxima é de cêrca de $10 \mathrm{~km}$, com comprimento de $23 \mathrm{~km}$, ocupando área silperior a $100 \mathrm{~km}^{2}$, extendendo-se, no entanto, anda mitos quilometros para SW.

As cristas majs alevadas da sorre da Cantareira atingem quase $1.200 \mathrm{~m}$ de altitude, com diperençs de nível má ximas de $450 \mathrm{~m}$.

As rochas encaixantes são representadis principelmente por xistos e filitos e subordinadamente por quartzitos. A orientação ostrutural predominante das oncajxantos E. NE-SW, quase sempre paralela ao alongamento do corpo de granito. Com a intrusão granítica, no contato $\mathrm{NE}-\mathrm{E}$, as cncaixantes fo. ram doslocadas e perturbadas, acomodando-se no contôrno do corpo intrusivo. Wssa acomodação e visIvel não apenas na di recão dns oncaixantes, mas tambom no comportamonto do Iincamento que apresenta ângulos miores de caimento.

- granito cantarcira, chamado "Pinituba" por Mo meई Rếgo (1937) E ligeiramente mosocrético, dada a abundância de biotjta, com arranjo sub-paralolo, imprimindo a folia ção da rocha. Ressritam-so nêlo grandes cristais do microclí nio, brancos ou rósos que, no goral, nẽo acompanham a fol ta -

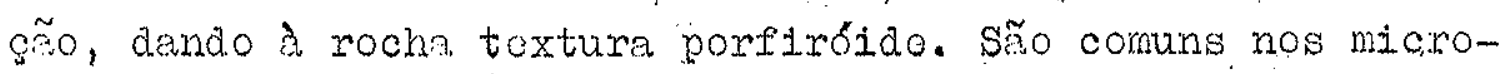
clíntos, inclusões de biotita, geralmente sem orientąão.

Nos contatos com os grandes cristais de microclínio 
6. froqüente o doslocamento do placas de biotita, sugerindo a comodação dêste mineral por ocasião do croscinonto do microclínio. A distribuiça o freqû̉ênoia dos grandos cristais de microclínio são hoterogêneas, às vêzes, num mesmo afloranento. In zonews pegmatódes nota-se abundsricia de foldspatos quo diminuom gradualmento om núnoro e tamanho, passando a zonns onde a textura of quase oquigranulier.

Em algumes freas, perto do contato com as oncaixantes o mesmo no intexior do corpo granítico, cxisten zonas ondo os cristais de microclínio chegem a atingir $10 \mathrm{~cm}$ do com primonto ou mais, dispostos peralclamente ìs placas de bioti ta. Nestos casos a folingão aprosonta pequonas dobras do flu xo; irregulares, indicando grande mobilidado durnte a forma ção dos feldspatos.

Ao Iongo do limito norte do granito Cantaroira o contato raramente é brusco, sendo mais comm uma zona de tran sicro onde se intercalnm, paralelanente ao contato, zonas gra níticas pegmatóides o xistos. Locelmente estas zonas pegma trides são ricas de tumalina. Qunndo não pegmatbide a folis

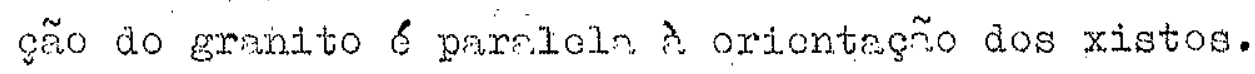

Nis srer do cont to NE do grenito, as encrixuntes sorrerm loculinonte neonodregño considorńvel, de sté $90 \mathrm{om}$ re Inç̃o d estrutura regional e nos xistos, o sngulo de crimonto do linomento, pode ultrapasser 359. o contato nostr área tambóm ore f.brusco ou de transição, altornandome xistos o zonns graniticas.

Ao longo do contrto NE-E os xistos sofrerm deformaçño intonsa provoomdo pronunciado enrugrmento o plissmen to. Nos ximtos formam-se dobras de escrla mesoscbpica. a microscbion que se refletem trmbem na escala megascbpica. o mesmo fenômeno ocorre também, mbora com monor intonsidnde, na irer do contrto $S E$.

Nestas dobras socundárins e posigño dos oixos. Be ramonto concorda com a diroção dos cixos des dobras meiores, mas apresentr grandos variaçõos no ceimonto. (\$igs.ns. 5,6 e7) Como jémencionado, a follagẽo no granito é param Iol a e forma alongada do corpo intrusivo. A direcão o o caimento do lineamento dos xistos a anfibolitos inclusos no gra 
nito concordem tamberm com os des onceixantes, sugerindo a for ma de un domo alongrido.

o mergulho de foldnça é variével, tanto no ângulo como no sentido do mergulho.

Comun no granito Cantaroju 6 abundancia do xong litos do escria mososcbpica e grandos zonas do xistos e anfi bolitos, en escala megascopica, consorvadqs no interior. Algumas zonas dêstes xistos possuon quase I km do lnxgura, po dondo o comprimonto ultrapassar $8 \mathrm{~km}$. Nos anfibolitos o Iino amonto decorronto do alinhamonto do primas do anfibólio ef frequentomento ber desenvolvido. Nos contatos froscos com. o granito, o anfibolito mostra ovidôncias de retassomatismo.

b. Granito Mairiporã.

- granito Mairiporã aflora no norte da cidade de Nririporã formando um "stock" alongado de direçño NEI-SWW . Possui coriprimento de $14 \mathrm{~km}$ e cêrca de $4 \mathrm{~km}$ na 1 rorgura méxima, ocupando area pouco superior a $30 \mathrm{kn}^{2}$.

Ressalta-se morfologicamente formando una pequena serra, com altitude náxima de $1.150 \mathrm{~m}$ e desnível, no. lado sul, de $400 \mathrm{~m}$. Istá encaixado en xistos e filitos, geralmente alterados ate grmude profundidade: Nestes estão preservadas estruturas originais como estratificação e lineamento. beli como variações na granulação de estratos originalmente majis argilosos e mais manosos.

A orientação geral das encajxantes é NME-SWW, pre domlondo o lineamento com cailuento para NE, do até 20\%. Na Erea SW do corpo granltico, as encaixantes estão locaimente o rientadas para NW.

o contato $\mathbb{N}$ do granito Mairiporã baralelo con $n$ diregão das encaixantes e o contato sul, ao longo do rio Ju

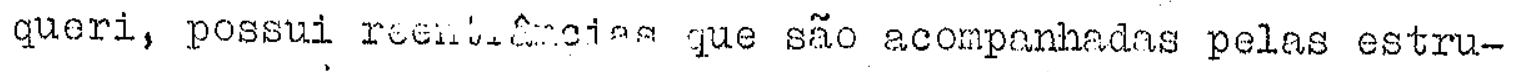
turas das onchixontes istes mostram nítida acomodnço por oca siño da froe intrusiva.

A rocha possui côr cinza clara, onde se ressaltam cristais de uicrocínio, de côr branca, con comprimento nedio de $2 \mathrm{~cm}$, que em certas zones lutitadas atingen 5 cr. Nas proximidades dos contatos o granito apresenta folingeno níti- 
ser em zonas fracamente pegmatóldes; onde orientam-se sub. -paralelamente às nlacas de biotita

Ao redor dos cristrais maiores de microclínio, as placas de biotita acompanham o contômo, indicando desloca mente destas por oca sião da formação do microcifnio.

o granito 6 rico em xenolitos, geralmente de poucos declmetros de comprimento, constituidos de xistos e rara mente quartaitos. A orienticão dos xenblitos é paralela a fo Iiação do sranito, Exequentemente com contatos bruscos. Nã̃o raro, reswaltam-se nos xenolitos de xistos, porfiroblastos de microcínio, semelhantes aos do granito (foto n. 3 ).

como já dito, a foliação do granito é melhox deșen volvida nas proximidades dos contatos e, principalmente na zona terminal. NT, a folią̧̃o assemelha-se à estrutura gnáissica, com interso cisalhamento dos minerais. o mergulho da roliaça para o interior do corpo granítico, ao longo dos contatos norte e sul, sugere gue o granito tenha forma lenticuiar.

c. Granito-gnaisse.

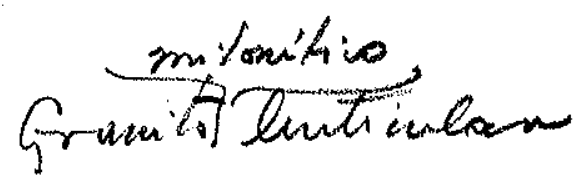

Lo norte do eranito iairiporã, aflora un corpo sra nítico, parcialmente representado no mapa geologico, encaixa do em xistos e filitos. Ressalta-se morfologicamente, en relação às encaixartes, ocupando as partes meis elevadas. No mapa geologico é apenas fepresentada a area $W$ dêste granito, que aumenta em largura para $E_{\text {. }}$

Como ja dito, difere dos outros dojs corpos granfticos descritos, pela sua estrutura fortemente orientada, pa ralela às encaixantes. Possui forma de curha, com îergulho paralelo às encaixantes. Na zona terminal desta cunha de granito, os efeitos do tectonismo foram mais intensos e transformargn o jumito numa brecha tectonica, com estrutura de aspecto de "flaseñn . Wũo presentes numerosas raixas milonfticas, com espessuras variando desde centioetricas a decinetricas.

- Os melinores contatos do sranito-gnádsse com as oncaixantes são observados em cortes da via Fermão Dias e na antige estrada de rodagem são Paulo-Atibaia. As . onsai- 
xantes são xistos e filitos em alternancia com camadas de me tassiltitos e quartzitos finos. O contato com o granito é brusco e ambas as rochas achnin-se. intemperizadas, aflorando granito fresco a um metro do contato. Nas encaixantes não se notam sinais de movimentação, ao passo que o granito: já no

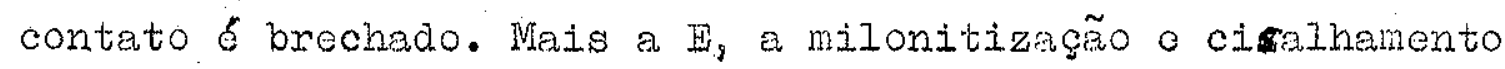
no granito não são tão consplcuos, mas a foliação é ber de scnvolvida. A atividade tectônica que aretou o granito-gnáis se foi tepetida, pois of milonitos são cortados por falhas.. mals ou menos paralelas às zonas de milonitização.

Im lâmina delgảda ressaltam-so porfiroclástos dẹ foldspatos orientados e ombebidos nura matriz einamente gra mulada, de granulos do quartio, feldspatos o moes. Não raro a biotita esté altcresla para muscovita.

morriroclastos do microclinio as intusós de plagioclásio e biotita exibem as mesmas relações paragenétioas que nos granitos.

Ners zonas onde cisalhamento o movimento tectônico foram intensos desenvolveu-so textura sluidal, na qual se ress selten pegixonos porfiroclastris de feldspatos. (fotomicrogra(ia. $n \cdot 6)$ 


\section{$V$ - PETROGRKIF DOS GRINITOS}

\section{PINGIOCLASTOS}

Thn geral os plagioclásios formam nos granitos a porção mineral mais abundante. O tamanho, forma e estágio de alteração são muito variáveis, ocorrendo desde pequenos grãos, de contômo irregular, até cristais grandes, com comrimento superi or a $1 \mathrm{~cm}$. A composição varia de An-20 a An-30, predominando os de composição $4 n-25$ a in-28, ̀̀s vêzes, com pequeno zoneamento oscilatbrio. As geminações mais comuns são soundo as leis da AI bita e Periclínio e menos frequentemente segundo Albita-Carlsbad.

Predominam cristais xenomorfos, com bordas irregula res e corroidas, mas podem oconrer tamben cristais com tendên cia cutomorfa.

Nuito comum e' a ocorrência de cristais quage fres can associados a outros alterados, nos quais se observam abun dantes inclusões de palhetas de sericita, muscovita, grânulos de epídoto e caolinita (?). Não raro estas inclusões são bem pequenas, dando aos cristais aspecto "nublado".

$\therefore$ distribui ão das alterações nos plagioclásios é heterogênea, existindo desde uniformemente espalhadas por todo 0 . mineral, até alteraça incipiente nas bordas ou na parte central. .

I muito frequente a existência de alteraçós nos plegioclásios dentro do microclinio. Nestes casos, os plagioclém sios estão bastante alterados na parte central que é delimitada bruscamente por uma auréola lfimpida, de espessura ao redor de 30 a 40 microns. Opticamente as aurélas estão em continuidade com - núclco mas apresentam refringência ligeiramente menor e maior birrefringencia, possuindo portanto mais moléculas de albita. (rotomicro: grafia n. 3)

Estas inclusões de plagioclásio são remanescentes. não assimilados pelo microclínio, mostrando vários estágios de transformação. Lssim, nos plagioclésios maiores, os con - 
tôrnos são normalmente irregulares e corroĺọ, enquanto que nos menores a forma é geralmente arredondada.

Oo plagioclásios pertencem a duas geraçöes, o que é indicado pela existência de cristais de plagioclásios seri citizados inclusos em outros quase frescos. A composição dos plagioclásios da segunda geração poderá ser de até An-30.

Nos plagioclásios da primeira geração a intensidade da alteraça que originou a sericitae oeploto foi maior. Nos da segunda geração a alteração é incipiente, normalmente nas bordas ou inexistente. Possuem tamanho variável e podem con ter inclusões de quartzo, plagioclásio da primeira geraçẽo, às vêzes, intensamente alterado, biotita e raramente, em cris tais frescos, pequenas anas de calcita. Nos maiores a tom.... dência é para idịomorfismo, mas as bordas são denteadas, com pequenas extensões anastomosadas, para os minerais vizinhos. que são englobados parcial ou totalmente.

Nos contatos com microclínio, o plagioclásio frequentemente a mi mequítico exxncionalmente, quando o pla gioclásio está incluso em microclínio. Nirmequita ocorre nos plagioclásios das duas geraçós. Em zonas cisalhadas, o pla gioclásio pode apresentar-se com planos de geminaça curvos. De modo geral, os feldspatos são mais resistentes a aça de esforços mecânicos, formando porfiroclastos ovbides ou angulosos, rodeados por minorais finamente granulados. (Fotomicrogratias ns. 2 e 6)

\section{MICROCLINIO}

- feldspato potásico obsemado nas rochas da re gião é o microclúnio, constituindo mineral conspícuo nos gra nitos, A ocorrência dêste mineral é mito variável e aparece desde a forma de pequenas zonas, de contômo irregular, om

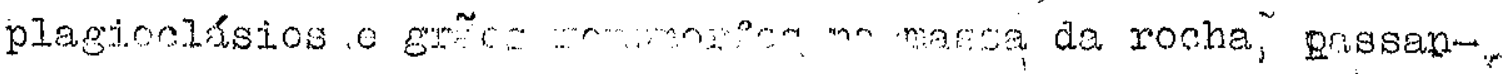
do gradualmente a megacristais, bem formados, porfiroblas tos, cujo comprimento poderá exceder $10 \mathrm{~cm}$.

com excegão dos cristais maiores e megacristais,

a forma e normalmente jrregular, com bordas frequentemente suturadas. Comum é a geminação míltipla em grade e mais rara a de Carlsbad. No geral o microcjínio apresenta-se fresco, 
contendo frequentemente inclusões de outros minerais, senco os mais comuns plagioclásio, quartzo, biotita, epldoto, seri. cita e titanita. As inclusões de biotita e plagioclásio, em alguns cristais grandes, estão dispostas paralelamente às fe ces do cristal (fig.n.15).

1 provável que as inclusŏes nos porfiroblastos de microclinio, que não se formaram por reações internas subsequentes, fizessem parte da massa rocha antes do infcio do crescimento dos microclínios e àmedida que êtes cresceram, as inclusoes foram deixadas "in-situ" por uma das seguintes razões:

1 - a superficie do porfiroblasto não forçou o desloca mento dos grãos.

2 - os grãos; por al guma razão, não foram substituidos pelo cristal quando crescia por substituição

o microclínio mostra nitidamente orisem de substituição, seja crescendo dentro de plagioclásios e substituindo-os ou desenvolvendo-se sob a forma de poiguiloblastos, en globando os outros minerais e assimilando parcial ou total mente os plagioclásios. As vêzess, quando se forma dentro de cristais grandes de plagioclásio, inicia-se o desenvolvimento progressivo do miorocínio em vérios setores do mineral. o feldspato potásico é freqưtentemente pertítico, ocorrendo as vênulas de albita melhor desenvolvidas nos microclinios da massa da rocha que nos porfiroblastos. As vênulas de pla gioclásio apresentam-se sob forma de finos cordéis dispostos de nodo variado, ora ontrelaçados, ora paralelos ou mesmo ir. regulares. A intensidade das vênulas de albita varia não so nos microclfnios de uma mesma lâmina, mas também poderá ser variável em diferentes zonas do mesmo mineral. Normalmente, as vênulas de albita são mais frequentes nas bordas do micro clínio ou ao redor/plagioclásios parcialmente substituidos, dentro do microclínio. Neste mineral, zonas turvas bem delimitadas são indŕcios da substituição total de plagioclásios

\section{QUAPTZO}

Seguindomse aos feldspatos, o quartzo ef o mineral 
mais abundante nos granitos, com volumes variando $\because$ de 15 a 30\% da rocha. quase sempre de contôrno irregular e rico em suturas. Im quase tôdas as lâminas estudadas apresenta si nais de esforços, em intensidades variáveis, mesmo, às vêrzes, quando incluso no microclínio. Os indicios de esforçós e ca taclase são a forte extinção ondulante, fraturamento dos grãos, formaçẽo de rosários alongados e agregados de micro grânulos ao redor de grãos maiores, tambem fraturados. Fim zo nas mais eisalhadas acumulam-se microgrânulos de quartzo ao redor ou nas zonas de "sombra" de cristais de feldspatos maio res, menos afetados pela ação dos movimentos. (rotomicrografia $n .5)$

São comuns inclusões sólidas, microscbpicas, de ma terial opaco, provàvelmente hematita, dispersas na parte cen tral ou mais regularmente ao longo de planos.

Não raro existem concentrações mais ou menos alon gadas, de vários milúmetros, de grande número de grãos de quartzo, sugerindo sua preexistência ao se formar o granito. J Em zonas de contato, principalmente no contato sul do grani to Nairiporã, a indicạão da contaminação de grãos de quartzo anteriores é ainda mais sugestiva, não so pela abundância, mas também pela uniformidade da forma e tamanho, tanto na ma triz como em inclusões nos microclínios. Neste caso, a extin ção ondulante é ausente ou fracamente desenvolvida. (fotomiorografia n.9)

\section{BIORIRA}

E o.mineral máfico dominante, frequentemente com àsposição sub-paralela, determinando a foliaça da rocha. tamanho é variável, mas, no geral, as placas possuem comprimento inferior a $2 \mathrm{~mm}$. Mais comum te biotita esverdeada, com pleocroismo: X (amarelo esverdeado) e $\mathbf{L}$ (verde-escuro a qua se preto), $N_{y}=1,62$ a 1,63 . Biotita parda ou castanho-esverdeada é menos ruequente e quando existente, pode mostrar pas sagem para côr esverdeada nas bordas e ao longo de planos de clivagem. As biotitas pardas e esverdeadas são normalmente rodeades de grânulos de leucoxênio e não raro possuem agulhas de rut1lio. Na biotita são comins inclusões de titanita, apa 
tita, zircão, alanita, epídoto, opacos e quartzo e pode esm tar inclusa em microclínio. Zircão e allanita formam halos ple ocrbicos e raramente titanita (ou xenotima?).

Em áreas onde a biotita é de côr castanha, a rocha normalmente apresenta pequena intergidade de deformaça nas biotitas o cisalhamento nos grãos de quartzo. Bm áreas movimentadas, a côr é esverdeada, indicando ser esta côr secundé ria e a alteraçéo consegự̂noia da aç̃o de esforgos e posteri ox percolação de soluções hidrotermals. Segundo Whohwartz (1958) a alteração de biotita para clorita of uma feição ca-\} racterística de alteração hidrotermal.

A biotita apresenta várias fases de transformaça para clorita, iniciando-se com a libertação de 'Tio, que se concentra em microgrânulos de leucoxênio ao redor do minexal e também ao longo de planos de clivagem. No estágio seguinte passa a ter côr esverdeada, devido ao enriquecimento relativo on ferro como consequência da perda de titanio (Ha11, 1941.) e finalmente passa à clorita.

As inclusõos de acículas de rutílio, no processo de cloritização, dão Iugar a agregados de leucoxênio, às vệ zes, conservando a nesma posição das acículas o xo estégio de clorita o rutilio desaparece, permanecendo os grânulos de leucoxênio ao redor do mineral. Istes derão origem aos crism tais de titanita. Im algumas lâminas, podem ser reconhecidos num indivíuo apenas, os vários estégios do cloritizeça da biotita (fig.nel6).

Em zonas movimentadas e cisalhadas alcm da alteração para clontta, a biotita pode alterar-se para muscovita, principalmonte nas partes terminais do mineral e ao longo dos planos de clivagem. A prosenga de epídoto (zoisita?) dentro da biotita verde, não raro de contomos irregulares e englobando a biotita, parece indicar que o eṕdoto é também produto da alteracõo da biotita.

\section{ACESSORIOS}

Titanita.

e um minerna acossbrio comum, não so nos grenitos, 
mas também nos hornfels e xistos encrixantes dos granitos. 6 ăn comuns cristais idiomorfos, que chegam atingir $5 \mathrm{~mm}$ no seu maior comprimento, às vêzes, com geminą̧̃̃ multipla.. As rela cões prragenéticas dêste mineral com a kiotita jk foram descritas. Outra indicação da origem scoundária, nos cristais maiores, são as inclusõos de apatita, zircão e biotita. Nas zonas granftices onde a cloritização das biotitas é mais in tensa, os cristats de titanita aumentam om numero o tamanho. As vếros, apresentam fracos halos pleocróicos o redor da bi ticta.

Allanita.

Como a titanita, a allanita é froquente nos xistos; hornfels e grenitos. A forme idiomorfa é comum, bem como a geminação (100). Normalmente esté alterada, em proporções va riéveis, chegando a ser quase isbtropa e envolvida por eprdo to (fotomicrografia n. 4).

Em algumas lâminas foram observados, na biotita, ha los pleocrbicos de pequena intensidade ao redor de grênulos de nanitá.

Apatita.

Prisuss de apatita ocorrem em múmoro o tamanho variáveis, que chogam atingir $5 \mathrm{~mm}$ de comprimento, em lâminas onde as biotitas estão bastante cloritizadas. bastante pro vável que alguns cristais de apatita tenham origem tardia ou secundária, pelo fato de conterem inclusoes de outros mine rajs, inclusive biotita.

Zircão.

Im alguma lâminas grânulos ou prismas de zircão são abundantes e noutras, quase ausentos. Quando incluso na biotita, o zircão forma halos pleocróicos intensos e normalmente possui forma prismática.

Spŕdoto.

Como ja descrito, grânulos de epídoto sño comuns dentro dos plegjoclásios soricitizados. Ocorrem tembém entro 
os demais minerais da rocha, las vêzes, formando oristais idi omorfos ou hipidiomorfos, que podem uItrapassar. I mm de com primento o geralmente associados à biotita. Possuem inclusões de zircão, apatita, opacos o allanita. Im olgumas zonas de milonitização antiga, faixas vordes centimétricas são consti tuidas essencialmente de epldoto. Moraes Rôgo o Souza Santos (1938) consideram a clinozoisite originada de plagioclásios - o eṕloto como mineral deutérico da fase final da cristali zação do magma. Coutinho (1953) admito pare o epidoto dos granitos da região de são Roque uma origom tardia, hidrotermal ou socunderia.

Muscovita e Sericita.

Sempre. secundária, formada a partir de biotita ou plegioclésios. Nos turmalina granitos a muscovita 6 , aparentomonto, primária.

Turmalina.

1) um acessorio raro e acidental nos granitos, mas comum on zonas pegmatbides e turmaline grenitos, formando prismas que atingem dimensõos centimetricas.

Opacos.

Os principais acessórios opacos, nos granitos, são magnotita, titenomagnetite ou ilmenita e pirita. Nos opacos, ricos em $\mathrm{TiO}_{2}$, f́ comum ume aurẹola de grânulos de leucoxônio que os substituom parcial ou quase totalmentc. 
Para a "mise-en-place" dos granitos podem ser aven tadas as seguintea hipótẹses:

1 - Intrusão e diferenciação de magina granf́tico, com ou sem assimilação das encaixantes.

2- Granitização regional.

3 - Intrusão sintectônica de magma ácido, assimilação parcial das encaixantes e posterior metassomatismo.

\section{$\operatorname{xxx} \S \mathrm{xxx}$}

1 - Intrusão e diferenciação de megma granfitico, com ou sem assimilação das encaixantes.

A Idéia de que os granitos tipo "Pirituba", na sé rì São Roque, são resultado da consolidação de magma granltico foi defendida por vérios Autores. Para Moraes Rêgo e Sou za Santos (1938) o granito que forma a serra da Cantareira o riginou-se por "consolidação em condições bastante profundas que asseguram processo lentc na sequência normaln. Barbosa (194.1) no estudo dos granitos da área de Apiar considera o granito como "um produto classico da cristalização de um magma granfitico". Coutinho (1953) adnite para os granitos da região de São Röque origem magmática e intrusiva, acompanham da de contaminação considerével das encaixantes . Cordani et al. (1961) consideram o granito Cantareira como provável in trusão pós-tectônica formado "por simples cristalização a par tir de magma de composição ácida", apesar de admitirem assimilasão das encaixantes.

Contra a hipótese acima devem ser mencionadas algu mas particularidades estruturais e texturatis dos srant tos, es pecialmente os estudados neste trabalho:

a - Admitindo ser a foliagão do granito resultado do fluxo do magma durante a intmusão, deveriam estar orienta 
dos não sర́ as placas de biotita, mas também os "fenocristais" de microclínio. No entanto, quartzo, biotita e plagioclásio podem apresentar evidências de deformasão anterio a mim croclínio.

b - o crescimento tardio do microclinio, substitum indo parcial ou totalmente plagioclásio, já foi descrito à pag. 23 .

c - A existência de uma seguma geração de plagioclésios, sem apresentax fen menos de sericitização e epidoti zação, ou apenas de forma incipiente.

d. Im zenólitos de xistos, nos granitos, ocorrem porfiroblastos centimétricos de ricroclfnio, idênticos aos dos granjtos, indicando que oresceram em idênticas condições. (foto 3.3 .

e - o marcante paralelismo entre a orientação esm trutural dos xistos e anfibolitos dentro do granito Canta reira e a foliação do granito, bem cono o paraleljomo da fo Iiação dêste com a orientacão das encaixantes, exclui a pos sibilidade de ter ocorrido irntrusão de nagma como um todo. Se êstes xenblitos de escala megascopica tivessem caido den tro do magma ou cômara magnética, suas posições cortumente serian orientadas ao acaso.

f - A grande variaça dos volumes de quartzo .e feldspatos nos granitos (fig. n. 2) indica que além da considexável assimilação, de rochas preexistentes houve variaço na intensidade do processo responsável pela formação dos feldspatos, especialmente os potásicos.

2 - Granitizą̧äo regional

o primeiro pescuisador a defender a tese da origem + dos granitos tipo "Pirituba", na série são Rogue, por proces sos de granitizạãa, foi Guimarães (1936,1937).

observou e descrever minuciosamente o processo da microclinjzação a partir do oligoclasio e quartzo, concluinudo nequela época ter sido o granito uma rocha originalmente de "composisão quartzo-diortitica que foi milonitizada, como 
mostram os núcleos de granulação fina, alterados e posterior mente sranitizado por embebição feldspática."

A primeira vista, o paralelismo das essmuturas das encaixantes com a dos granitos, a abunância de xenólitos e tambem as zonas remanescentes de xistos e anfibolitos no gra nito Cantareira, alérn das relaçôs paragenéticas dos minerais do granito, poderiam sugexir origem metassomática para os corpos eraniticos.

Para o autor, no entanto, as relações estruturais Intimas entre encaixantes e granjtos que serão discutidas a seguir, alem do baixo grau de metamorfismo das encaixantes, indicam que a fase metassomática por si sb, não poderia ter sido a responsável pela origem dos corpos granticos.

3 - Intmas̃o sintectônica

Os corpos intrusivos da Éea estudada, pela forma, estrutura e posição estrutural en relação às encaixantes, en quaoram-se dentro da classificação de granjtos sintectônicos, ou "Intrusions granitiques syncinematiques" de Raguin (1946).

No conceito aêste Autor, êstes granitos formam gran des faixas ou silla lenticulares, concordantes com os eixos tectônicos, mostrando uma textura variável; frequentenente gnáissica, inclusões orientadas e milonitos concordantes com as estruturas associadas, Indịcando prolongação do movimento durante e apbs a consolidação.

Também pela composicão mineral, com presença do. porfiroblastos de microclínio, numa matriz granodioritica, si tuam-se neste tipo de jazigo, segundo descricôes de Marmo (1962).

Read (1957, p. 320), na discussão sôbre intrusões sin tectônicas, arirma cue a forma e estrutura do corpo intrusivo, por si sós, não são suficientes para gem, havendo necessidade de uma série de observacões de deta Ihe, que levam frequentemente a deduçöes diflceis.

Serão a seguir analisadas e discutidas as relaçôes - o comportamento des encaixentes e estmuturas internas dos corpos granfticos a fim de possibilitar um quadro de sua evo 


\section{Inẫengeotectônica.}

a. Encaixantes e contatos com granitos.

A forma lenticular nos corpos intrusivos é particu. larmente bem desenvolvida no granito-gnaisso e granito Mairl porã, com suas terminacõos em forma de cunha e contatos paralelos à estrutura das encaixantes.

No granito Cantareira a forma lenticular no contam to $\mathrm{NE}$ não 6 tão consplcua, mas de modo geral a direção estru tural das encaixantes acompanha os contatos.

As encaixantes nos granitos Wairiporã e. Cantareira sofreram acomodação por ocașião da fase intrusiva. Esta acom modação 6 bem marcante na érea do contato $\mathrm{N}-\mathrm{NE}-\mathrm{E}$ do granito Cantareira a a Iongo do contato sul do granito Mairipora, on de as direções de acamamento, nes rochas metassedimentares, a comparham as reentrâncias e saliências do granito.

Esta acomodação, resultante da tase intrusiva, pro vocou um aumento no ângulo de caimento do lineamento e dos eixos das dobras de arrasto, principalmente junto à parte terminal NE-E do granito Cantareira.

Estruturas similares nas encaixantes, resultantes da fase intmusiva, foram descritas por Teefethen (I954), Inoff (1955), Turner e Verhoogen (1960), Knild e Knil1 (19610 $\theta$ outros.

Principalmente a Iongo do contato norte do granito Cantareira notam-se, nos lilitos existos, crenulaçôes e microdobras, com eixos de caimento variúvel, associadas a pe quenas falhas reversas, de grande ângulo de mergulho. (figs. ns. 5,6 e 7 )

Segundo Rickard (1961) crenulações estariam associ adas a dobramento secundário e superimpostor podendo șer a rientaç̃o dos esforços a mesma da deformação antexior.

As direções das crenulações e microdobras são, em geral, paralelas à dobras natones e tambem ao contato com o granito. Apenes varia a posigão do caimento dos eixos das mi crodobxas e crenulaçôes, gue em pequenas distêncjas, num mes mo alloramento, mudam de 00 a 902. Essas microdobras e crenulaçöes devem ser resultado da acomodação das encaixantes 
menos competentes, por ocasiäo da fase intrugiva que atuou como esfốrgo superimposto ao dobramento regional.

Nos três corpos granticos os contatos com as encaj xantes são intrustivos $\theta$ seralmente nftidos, com exceção do contato $\mathbb{N}-N E$ do granito Cantareira. Infelizmente, as encajxan tes estão quase sempre alteradas, mas boas exposicões frescas ocoxrem no contato norte do granito Cantareira, nas proximidades da cidade de Mairiporã, na Pedreira Cantareira.

Neste afloramento a direção dos xistos é paralela ao contato com o granito, ocorrendo injeçós de material gra nftico ao longo dos planos de xistosidade. O naterial injeta do 6 similar ao dos granitos. Os leldspatos apresentam as mes mas relagões paragenéticas, notando-se apenas uma maior in tensidade na sericitização epidotização. Nas biotitas do grantto a alteraçõo é apenas incipiente, com formacão de grâ nulos de leccoxênio no redor do mineral.

Já no xisto, os plagioclásios não estão sericitiza dos e a biotita é fresca, sem libertagão de titânto, com ple ocroismo bastante rorte: $X$ (amarelo-palha) e $Z$ (castanho avermelhado).

Nos contatos: do grant to Mairiporã a rocha possui, numa fajxa de alguns declmetros de espessura, granulacão fina e textura fluidel bem desenvolvida. Em lâmira delgada, a abundância de concentraçóes de grãos de quartzo, de tamanho unjforme, sugere contaminação das encaixantes.

b - Estrutures internas

Nos granitos, das estruturas internas, a mais cons picua E foliaçóo e f formada principalmente pelo alinhamen to paralelo das placas de biotita e, apenas excepcionalmente. pelo arranjo sub-paralelo de porfiroblastos de microcínio.

A melhor desenvolvida nas proximidades dos conta tos, chegando apresentar, chs vêzes, estrutura gnéissica, to passo que na parte contral "a orientação das biotitas" E fraca merte perceptível ou pràticamente ausente.

Em algumas zonas onde deve tex havido grande mobjlidade, os minerais - neste caso biotita e feldspatos - for- 
mam dobras de pluxo, imregulares.

A foliação nos eranitos, com merguinos fortes nas proximidades dos contatos deve ser considerada uma le1gão primária e indicadora de uma fase magmética parcialmente cris talizada e ainda em movimento.

A bem da verdade, deve ser mencionedo que tem sido criticada a Interpretação de considerar-se a foliagão como fejễo priméria, em corpos granfticos; onde esta b bem desen volvida has proximidades dos contatos e praticamente ausento na parte centraI. Read (1957, p. 230) menciona uma exemplo no qual a foliagæo de um granto grrissico foi interpretada diferentemente por 3 autores, como sendo:

- rocha intrusiva com deformação protocléstica.

- granito deformado no estado sblido por deforma são epizonal.

- granito sintectônico.

A favor da hipotese/ser a foliaça feição priméria deve ser mencionado:

a - Comportamento da foliaçẽo ao redor de xenblitos dentro do granito

As placas de biotita rodeiam os xenólitos acompa nhando o contốmo e irregularidades do contato como os xenó litos alinham-se paralelamente à foliagão regional, podemse concluir que êstes encraves não sofreram rotação após a consolidagão da maşa intrusiva (Balk, 1948),

Bsta orientaç̃o priméria nos granitos 6 interpreta da por. H. Cloos como devida ao fluxo do magma durante a in tmanão. Aamite ger a foliação paralela àm suporfloies de flu xo do magma en movimento (in Tumer e Vexhoogen, 1960).

b - As zonas de xistos e anfibolitos consexvadas dentro do granito, especiajmente no granito Cantareira, possuem orientação estmutural paralela è estrutura regínal das encajxantes e concordam com a foliação do granito. Esto paralelismo entre estruturas das encajxantes, foljagão dos granitos o ro manescontes da fase anterior à intrusão, principalmente os de cscala mesoscópica, conservadós dentro dos granitos, não po- 
de ser simplesmente fortuito.

o paralelimo entre oncaixantes e os xistos e anfi bolitos dentro dos granitos concorda tambem na orientação $e$ caimento do lineamento, o que poderta ser interprotado de três maneiras:

1. Estes remanescentes representam partes do teto da cêmara magmética, verdadeiros tetos pendentes, indicando que a intrusão ocorreu no fim da fase orogenética, quando a esstrutura tẹctônica regional já havia sido delimitada.

2. Zonas relicarias não granitizadas, segundo hipó tese anteriormente mencionada.

3. Remanescentes não assinilados pelo magma, sem ligação efetiva com o teto da cêmara magmática.

A favor desta possibilidade existem alguns dados de campo que devem ser mencionados:

- Um afloramento de anfibolito, formando aparentemente pequeno enticlinal dentro do granito Canta reira, na altura do $\mathrm{km} 538$ da via Fernão Dias, 6 capeado pelo granito. A sua orientação, bem como o caimento do linee mento concordam com a orlentação média dos xistos a anfiboli tos dentro do granito.

- Pequenas zonas de xistos, cuja escala não permi-m te representação no mapa, estão orientadas paraie lamente as zonas de xisto maiores.

- As árés maiores de xistos, na zone central do granito Cantareira, sugerem pela oxientaçẽo es trutural, representar um anticlinal parcialmente conservado. $($ perfic $(C-D)$.

c. Origem do magma

Fin zonas orogenéticas, principalmente pre-cambriam nas, é comum a existência de grandes jazigos graniticos ou granodioriticos ligedos diretamente è̀s fases orogenétices ou da tectônica tardia (Iate kinematic). Possuem formas alongam das, paralelas aos eixos de dobramentos e frequentemente com cristalizaçá paratectônica. 
Quase todos os bet6litos possuem zonas relicárias ou estruturas "fartasmes" relacionadas, às vênes, diretamente com as encaixantes. Estas zonas relicárias poderão ser con sideradas como prova de assimilação do magma intrusivo ou da granitizasão "irr situ", dejxando apenas as rochas menos tavo réveis à rormação do granito (De sitter, 1956).

Pare magma 6 adotado o conceito de Turner e Verhoogen (1960) como sendo material rochoso movel, consistindo principalmenț numa lase liquida com composição de uma fu.são de silicatos.

Durante o processo orogenético, a diminuição da pressão e a presença de água e outros voláteis baixarão ponto de fusão dass rochas. A combinação dêstes fatores permi tixâ a formação de lfauido magmático e sua intrusão para nfveis mais altos da crosta, em temperaturas relativamente bai xas (De Sitter, 1956, Tuttle e Bowen, 1958).

Fusões parciais deverão ocorrer ém profundidades de 10 a $4.0 \mathrm{~km}$ onde o gradiente geotérmico seria spuperior a $200 / \mathrm{km}$. Como gradientes geotermicos elevados (i.e., da or dem de $400 / \mathrm{km}$ ) são comumente encontrados em rochas sedimentares, f́ provável que líquidos de composição granfitica serão mais facilmente formados onde estiver presente, uma espêsaa cobertura de sedimentos (Tuttle e Bowen, 1958).

Winklex e von Platten (1958, 1960, 1961) obtiveram experimentalmente fusões anatêticas de corposição granftica a tonalltica, usando separadamente argilas com NaCl, argilas com Ca e grauvacas. Fm temperaturas pouco abaixo de 70090 e pressão de vapor de 2.000 atnosferas formaram-se fusões anatéticas iniciais e com aumento da temperatura, até 78090 , a fusão chegou a um máximo de $96 \%$ na amostra de grauvaca.

Dados experinentais citados por Tuttle e Bowen (1958) indicam que rochas de composição média de granitos po derão iniciar fusão a partị de 64080 e pressões de 4.000 $\mathrm{kg} / \mathrm{cm}^{2}$, em presença d'agua.

Na região estudada predominam rochas de origem per I Itica, não só nas encaixantes, mas tambẹm nas representadas pelos xenólitos conșervados nos granitos. 
As posições estruturais e o compoxtamento dos xism tos e das zonas de anfibolitos, no granito Cantareira, sugerem fortemente que estas inclusōes não sofreram grandes deslocamentos. Além dêstes fatos, não seria fácil imaginar a descida de zonas de xistos durante a ascenção de magma altamente viscoso.

o magma intrusivo deve ter-se formado pela fusão dos sedimentos, prinoipalnente pelfticos, do geossinclinal, em profundidades maiores e assimilado, na ascenøz̃o, facilita da pela atividade tectônica, as rochas de nuveis mais elevados.

As reações entre magmas kcidos e rochas sedimentam res ou seus equivalentes metanorficos levam também a um desen volvimento paralelo de minerais nos xenblitos e no magma con taminado. Os magmas contaminados, formados pela reação com folhelhos, tenden a ser enriquecidos em biotita (Turner e Verhoogen, 1960). Assim se explicaria a mesma associação mineralbgica dos xenblitos de rochas metassedinentares origi nalmente, pelŕticas e psamfticas e a abundância de bjotita nos granitos.

Segundo Tuttle e Bowen (1958), nas regiōes superiores, onde a quantidade de Ifquido e relativamente pequena, o efeito principal da fusão será a recristaljucão da fração não fundida, en fases cristalinas em equilíbrio com o líquido.

A ação entre o magna ou soluções magmáticas ativas e mbvejs e as rochas preexistentes leva à formação de granitos, onde previamente existiam rochas metassedimentares.

Como menciona Beloussov (1962), a. composicão ácida e uniforme dos granitos não 6 condição inicial, mas o resultado de um grande número de reações seletivas entre os compo mentes ativos do magma e rochas zo redor.

Para a formação dos sranitos da área estudada, pode-se admitir um volume relativamente pequeno do magma intru sivo, pelas seguintes razões;

a - existência de grandes zonas de xistos, no granito Cantareira, que não foram assimilados pelo magma. 
b- Os xenblitos, com estruturas palimpsésticas, possuem a mesma composição mineral que o grani to. Foram recristalizados em equilíbrio com o IÍquido, por ação de soluções provindas do mağ man

c - As perturbações e acomodações das encaixantes, cuja intensidade diminui à medida que se afasw tando contato, seriam causadas pela ịnjeção do magma que provocou aumento do volume.

d. Netassomatismo

L observaç̃o de que on grandes cristais de microclí nio nos granitos, xistos granitizados e em xenblitos de xism tos, nos granitos, apresentam as mesmas caracterlsticas e idênticos fenômenos de substituição de plagioclésios, sugere, fortemente que se originaram por ação de um mesmo processo.

A hipótese de que se trata de fenocristais, formados pelo resfriamento do magma está excluida, devendo-se admitir uma oxigem posterior na qual êstes feldspatos cresce ram quando a rocha já estava formada. Uma origem metassomática para os grandes cristais de microclinio, a partir de plagioclésio e quartzo, nos granitos tipo "Pirituba", já fol defendida por Guimarães en 1936. Tro estudo desta rocha, Gui-marães observou que o oligoclásio é rico em inclusões micros cópicas de mascovita e zoisita e substituido por microclí nio. Siste teria se formado pela substituição do plagioclésio e quartzo em consequuência do processo de granitização a parw

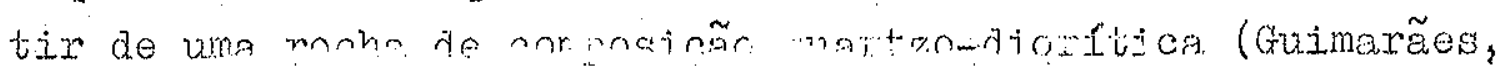
1936: " $931 \%$ \%

a Sericitizaçăo

Em tôoas as lâminas estudadas, de rochas contendo porfiroblastos de microclfnio, os plegioclásiós estucto verici tizados. Nos granitos estão sexicitizados principalmente of da primeira geração e possuem grânulos de epidoto com maior ou menor frequência.

As plaquetas de sericita podem estar dispersas rem 
gularmente no cristal de plagioclásio ou se concentrar ora mais nas bordas ou no interior e quase sempre associadas com epfaoto e raranente calcita.

A formaçẽo da sericita e epldoto c certamente ante rior ao microclínio. Plagioclásios inclusos no feldspato potássico tambern estão sericitizados e onde a substituição do plagioclásio por microclinio foi completa, podem permanecer grãos de sericita e epldoto inaicando a existência anterior de plagioclásio.

Como já foi dito, no contato do microclinio como plagioclésio, este ef frequentemente envolvido por uma pequena aurcola limpida, de espessura variável, de constituigão mais sbaica que o núcleo. O contato da auréola com o mícleo sericitịado 6 geralnente brusco quando a sericitização for menor. (fotomicrografia n. 3 ).

Segundo Andreata (1954) a sericitização se dé en conaições de metamorfismo tectónico epizonal, com forte pres são dirigida, unilateral e temperatura relativamente bajxa, numa recristalização em escala regional durante a orogênese.

Rara a área ora em questão, a causa da sericutiza̧ão dos plagioclásios nâo pode ter sido motivada apenas por fenônenos ligados à condiçôes de metamorfismo tectônico epizonal. A verdade que nas rochas encaixantes predomina o cara ter epizonal do metamorfismo regional. Durante e após a fase intrusiva pressões dirigidas atuaram sôbre as rocha's forma das, causando intensas deformações e cisalhamentos nos minerais. No entanto, nas lâminas estudadas dos anfibolitos, al guns certamente anterjores a fase intrusiva, os plagioclásios não estão sericitizados ou apenas parcialmente, quando nes tes se injciar a microclinizaçóco. Se a atividade tectônica fosse essencial, a sericitização dos plaßjioclásios deveria ser uniforme, não só nos granitos, mas também nos xistos e anfibolitos anteriores aos granitos.

mais provável que a sericitização esteja ligada diretamente ao metassomatismo do potássip. Como menciona Es kola (1956), a sericitização é o primeiro sinal do metassoma tismo, que leva também a ume descalcificação do plagioclásio (Narmo, 1961). 
Segundo Marmo (1961), ao microscópio pode ser visto aue o fenômeno da descalcificação do plagioclésio resulta na "albitização" do feldspato, com a tormação da auréola Ińm pjoda, mais elbitica e sericitizacão ou saussuritização.

Quimicamente a sericitização implica na introdução de potásisio a a causa da epidotização do componente anortita do plagioclásio seria a égua. Ainda segundo Marmo (1961) a seguinte reação esclare⿻pceria êste processo:

12. $\left(\mathrm{CaO} \cdot \mathrm{Al}_{2} \mathrm{O}_{3} \cdot 3 \mathrm{SiO}_{2}\right)+\mathrm{K}_{2} \mathrm{O} \cdot \mathrm{SiO} \mathrm{S}_{2}+5 \mathrm{H}_{2} \mathrm{O}$ anortita

$$
\begin{gathered}
\left.3\left(4 \mathrm{CaO} \cdot 3 \mathrm{AI}_{2} \mathrm{O}_{3}\right) \cdot 6 \mathrm{SIO}_{2} \cdot \mathrm{H}_{2} \mathrm{O}\right)+\mathrm{K}_{2} \mathrm{O}_{2} 3 \mathrm{Al}_{2}\left(\mathrm{C}_{3} \cdot 6 \mathrm{SIO}_{2} \cdot 2 \mathrm{HI}_{2} \mathrm{O}+\mathrm{S}_{2} \mathrm{O}_{2}\right. \\
\text { eplaoto }
\end{gathered}
$$

No interior do cristal de plagjoclésio sericitizam do ou saussuritizado, rodeado de uma porcão marginal mais al bltica, êstes compostos - epldoto e sericita - são uma prova da decomposição do componente arortita do plagioclásio.

Apesar de ser a sericitizacão o primeiro sinal do metassomatismo de potássio (Eskola, 1956), os sinais mais conclusivos do metassomatismo são o microclinio nos interst cios dos minerais da rocha e o microclínio atacario os pla gioclásios. Os remanescentes de plagioclásios encontrados no interior do microclínio, bem como a forma xenonorfa dêste, na maşsa da rocha, são indicação clara de sua formação posterior.

Sericitiząão anterior ao microclínio tem sido cim tada por mitos autores: Guimarães (1936, 1937), cheng (1943) Reynolas (1943), Harry (1953), Seistari (1951, in Bergstrom, 1963), Eskola (1956), Marmo (1956), Bergstrom (1963) e outros. D - Miciontiniząão

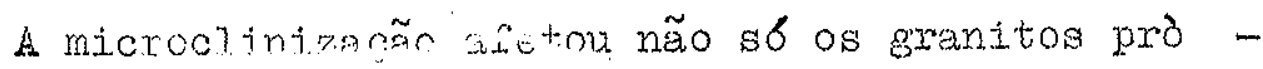
priamente ditos, mas tamoem os zenolitos, zonas de xistos e anfibolitos e em menor escala as enoaixantes, principalmente nas zonas de xistos granitizados

Como menciona Esrola (1956). não se pode escapar da 
conclusão de que a adjção de potásiso, por metassomatismo, em plagioclásjos anteriormente formados, 6 um fénôneno de ampla distribulễo nos granitos, meas 6 dificil obter-se uma idéia da importancia quantitative dos diversos tipos de metassomatismo de potásisio observado nos granitos.

Admite-se ser a fase metassomática responsável pela formaça dos porfiroblastos de microclínio e certanente também, pelo menos em parte, dos microclinios da massa da ro cha, alem de estar relacionada com o desenvolvimento de plagioclásios da segunda geração. Uma véz gue a identificação de eventuair feldsperos potássicos antexiores, ao metassoma tismo não 6 posslvel, não deve ser excluida a possibilidade dêstes terem solrido recristalizacão.

A sericitização dos plagioclásios é considerada co mo primeiro sinal de metassomatismo, mas é possivel que po tássio ocorra em quantidades diminutas nos plagioclásios (Eskola, 1956).

Para os granitos estudados, alguns dados de campo sugerem que o metassomatismo responsével pelo desenvolvimento dos porfiroblastos de microclínio deu-se numa fase pneuma tolitica-hidrotermal, pouco apbs a formậão da rocha.

Estes dados referem-se à posição dos porfiroblastos em relação à foliação nos granitos. Fm algumas éreas, cris.s.tais grandes, cujo comprimento alcança $5 \mathrm{~cm}$ ou mais, estão paralelos às placas de biotita. A foliação mostra dobras irregulares indicando ter havido condiçôes de grande mobilidade por ocasião do desenvolvimento dos cxistais de microcly nio.

o metassomatismo, localnerte mais intenso, provo cou nos granitos aumento de volume conseginente scomodação sob a forma de dobras de fluxo (Poldevarit, 1954).

seoundo Semenenko (1.960) metassomatismo desenvolve -se em zonas de alta mobilidade tectônica, gue possibilita a percolação de solucões.

o frequente e intenso cisalhamento dos miruerais dos granitos, não raro ausente nos porfiroblastos de microcls nio, mostra que a fase metassomatica poi precedia de esforsos tectônicos que possibilitaram, pelo cisalhamento da ro- 
cha, vias para percoląão dass solugôes responśáveis pelo metassomatismo.

Também merece menção a intensa oloritização das bi otjtas nos granitos e ausente, nos xistos mesmo, das vâzes, em contato direto com granito.

Chayes (1955) chamou atenção para us posibilidade de haver ligação entre o lenômero da cloxitização de biotitas e a formação de fellaspato poit́ssico.

sendo o potéssio um dos constituintes aa bioti ta praticamente ausente nas cloritas, deve haver consideré vel lịbertação e remoção daquele elemento, durante a cloriti

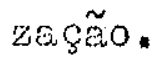

Como já mencionado, a intensidade de cloritização das biotitas nos gronitos não \& igual nem uniforme, existindo zonas com biotita parda, gexalmente em regiões onde o Erau de cisalhamento E menor. Esta cloritizaça diferencial da bjotita pode ter sua origem na ação hịdrotermal, permane. condo sem alteração onde não foi atacada. Como nas zonás cisalhadas a biotita é invarjavelmente cloritjaada, e provável que o cisalihamento tenha própiciado condiçoes favoráveis à percolação de soluções hidrotermais è remoção do potásio das biotitas.

No entanto, \& bastante improvável serem estas as únices fontes de potássio - sericita e biotita - responsáveis pelo desenvolvimento do microcitnio.

Como o metassomatismo este restrito aos erranitos, seus encraves e pequenas breas de xistos granitizados, que serão discutidas a seguir, deve-se admitix que a fase metassomatica esteve Iigeda diretamente ao processo gentictico dos corpos greariticos.

Das alscussões acima, parece bbvio que o fenômeno. metassomático poderá ser explicaāo por soluçōes ascendentes.

Como ja foi referido no captulo referente à ori gem do magme, admite-se que este se teria formado pelà fu sc̃o dos metassedimentos, principalmente pelíticos e psamiticos.

Nos trabalhos experimentais de Winkler e von Platw ten coram obtidas fusões parciajs a partix de argilas e quart 
zo, com excesso de água, en temperaturas de $7009 \mathrm{C}$ e press de 2.000 atmosfercs. Esta fus̃̃o é, comparada com o material primário, enriquecida em $\mathrm{SiO}_{2}, \mathrm{~K}$ e $\mathrm{Na}$. A fragão não fundida contem mais $\mathrm{Al}_{2} \mathrm{O}_{3}$, MgO e bxidos de ferro que a argila primé. ria. Do resultado dêstes experimentos nota-se que com aumento da temperatura os elementos necessérios para a formagão de feldsprtios sr̃o libertedos do sedimento. Contudo, não foí a fu sño contendo Si, IK e Na cue formou os porfiroblystos, mas sim øoluçõos derivadas da fusño anatetica. Os valoros tos dos êngulos dos eixos ópticos inaicam que os microclínios $s \in$ formaram em temperaturas moderadas (Spencer, 1938) e não a partir da fusão.

No entanto, Marmo (1962) admite que as fonter de potassio não seriam fusões graniticas, mas sim os sedimentos que, en condiêoos hidrotermais, libertariam este elemento que serie depositedo alhures, possibilitando feldspatizeção. Ainda a favor da hipótese/serem as solugốs deriva das do magme deve ser mencionado que sendo $\mathrm{K}, \mathrm{Na}$ e $\mathrm{Si}$ elemen tos de grande mobilidade, as soluçóes ascendentes, percolando os corpos granlticos, possibilitaram a formaço da segunda geracão de plagioclásios (Bergatrom, .1963 e semenenko, 1960).

c - Pertitas

O significado petrogenético de pertitas ainda problema controverso e nos casos em que estas se formam por processos de substituição, comm ef a substituição do feldsm pato potéssico pelo felaspato s6aico (Deer, Howie e Zussman, 1963).

Pertitas formadas durante o processo metassomatico, com substituição de plagioclásio por microclinio, foram descritas entre outros por Nickel (1953), Robertion (1959) e Bergstrom (1963).

Para os microclinios ora em aprêço, a intensidade das pertitas 6 heterogênea. Existern cristais sem pertitar $\mathrm{I}$ slveis e outros, na massa da rocha e porfiroblastos, onde as vênulas de pertitas estão intensamento desenvolvidas.

provável que a variação na djstribulgño das perm 
titas esteja relacionada diretamente com a paragênese dos mi croclunios. Nestes, formados parcialmente pela contribuiçẽo do plagioclásio, o desenvolvimento de pertitas é mais intenso que naqueles originados principalmente por ação das soluções responséveis pelo metessonatismo, se bem que a possibiLidade de se encontrarem sob a forma de criptopertita não de ve ser excluida. (fotomicrografia n. 8)

o aumento de vênulas de pertita ao redor de mitos plagioclésios remanescentes deritro do microcínio tambén está Iigado à fase metassomática $e$ no $\therefore$ declfnio da ativi dade das soluções, os plagioclékios inclusos não foram trans formados, mas permaneceram como remanescentes.

Por outro lado, em mutas lâminas pareco haver uma relagão entre a frequência e intensidade das pertitas e o grau de cisalhamento sofrido pela rocha. Assim, naquelas onde os grãos de quartzo não apresentam extinção ondulante pro nunojada e formação de agregados de microgrânulos a redor de cristais maiores de plagioclásio e microcjúnio, as pertitas são, menos comuns que nos casos onde o cisalhamento foi intenso.

Em alguns microclínios da massa da rocha podem exis tir zonas perifericas nas quais o volume de plagioclásio, nas lemelas, pode exceder o de microclinio, passando a antiperti ta. bem possivel que esta associação nẽo seja meramente fortuita.

Chayes (1952), na anbise de numerosas lâminas dè granitos contendo microclínio, observou que existe uma con cordência entre o grau de cisalhamento dos grãos de quartzo e a Prequếncia de pertitas no microclinio. Esta associação poderia sor assim explicada:

1. o. intenso eraturamento dos gräos de auartzo, ocorrido durante uma fase tectônica, proporcionou condições favoráveis è percolação de solu cões mineralizantes.

2. Os esforços tectônicos que provocaram cisajha mento e extunção ondulante do quartzo promove ran a demistura do microclínio metaestével, que de outro modo permaneceria hom g yneo. 
e- Composição dos sranitos

Como jé fot mencionado, a composigão dos granitos não é homogener, havendo oonsideráveis variacóes nos volumes de reldspatos, quantro e biotita.

A tabula abaixo apreserta a composigão nodal de 15 anostras, onde o oisaldamento e deformega foram pouco inter

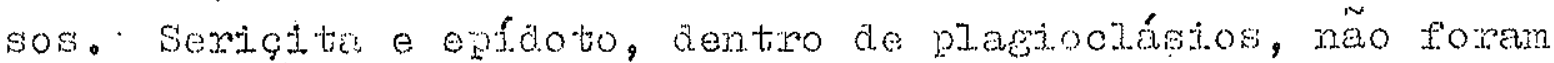
computiodos.

\section{TABETA III}

\begin{tabular}{|c|c|c|c|c|c|c|c|c|c|c|c|c|c|c|c|}
\hline Anostan $n$ & 1 & 2 & 3 & 4 & 5 & 6 & 7 & 8 & 9 & 10 & 11 & 12 & 13 & 14 & 15 \\
\hline Quartzo & 1.6 & 20 & 25 & 25 & 24 & 20 & 20 & 17 & 24 & 27 & .14 & 27 & 21 & 18 & 18 \\
\hline Plagioclásio & 29 & 26 & 32 & 19 & 29 & 4.2 & 33 & 53 & 37 & 43 & 17 & 45 & 43 & 43 & 39 \\
\hline Microclúnio & 31 & 44 & 27 & 38 & 40 & 17 & 37 & 19 & 22 & 19 & 58 & 19 & 5 & 7.9 & 13 \\
\hline Biotita & 14 & 8 & 8 & 3.4 & 4 & 24 & 7 & 7 & 20 & 8 & 7 & 7.4 & 28 & 1.5 & 22 \\
\hline Acessóntos & 10 & 2 & 8 & 4 & 3 & 8 & 3 & 4 & 7 & 3 & 4 & 5 & 9 & 5 & 8 \\
\hline
\end{tabular}

Amostras ns. I a 3 - Granito Mariporä

"no" 4. Granito Maimipora, no contato, com con taminaço de quertzo

" ns. 5 a 14- Gronito Cantareira

" n. I5- Xisto Granttizado

Na tig. 2, no dieframa dos volumes de quartzo,pla gioelásio e microcínio, nota-se que nos granitos existe uma variaço desde quaxtzomioritos até granitos verdadeiros, predominando, no entawto, granodioritos.

Das amostras mais pobres em felaspato potásioo, uma provém de xisto grantitizedo da Pedreira Coteca e as outras do granito Cantereira, em zonas pobres de porfiroblas tos de microcínio.

A mais rica em telaspeto potássjeo tambén 6 do sra nto Cartareira, numa eaixa rica em feldspatos e porre em biotita.

A tormaço do mioxocinio, wincipalmante dos por. fjroblastos, por substituicão parcial ou total de plagioolásio jálfol cutida anteriomente.

Felo diagrana da fig. 2 e pelas relacöos paragené ticas dos feldspatos nota-se claramente a tendenoia dos gra nodioritos passarem a granitos verdadeicos. No entanto, o problema da existencia ou não de falapato botásico antem 
rior a microcinjzaço ainda permanece aberto. Allons indí cjos que pormitem supor que a rocha original, da fase irtixu. siva, teria sido de caréter quartzo-dioritioo:

1. Mesmo na amostra mais pobre en mịcrocínio, ête mostra sua origem veraia e de substituição.

2. Nos xistos granitizados todo o microclfinio originoume durante o processo metrossonático, poje nos xistos não gra nitizados, próxtmos ao contato não ocorre peldapito potás sico. 


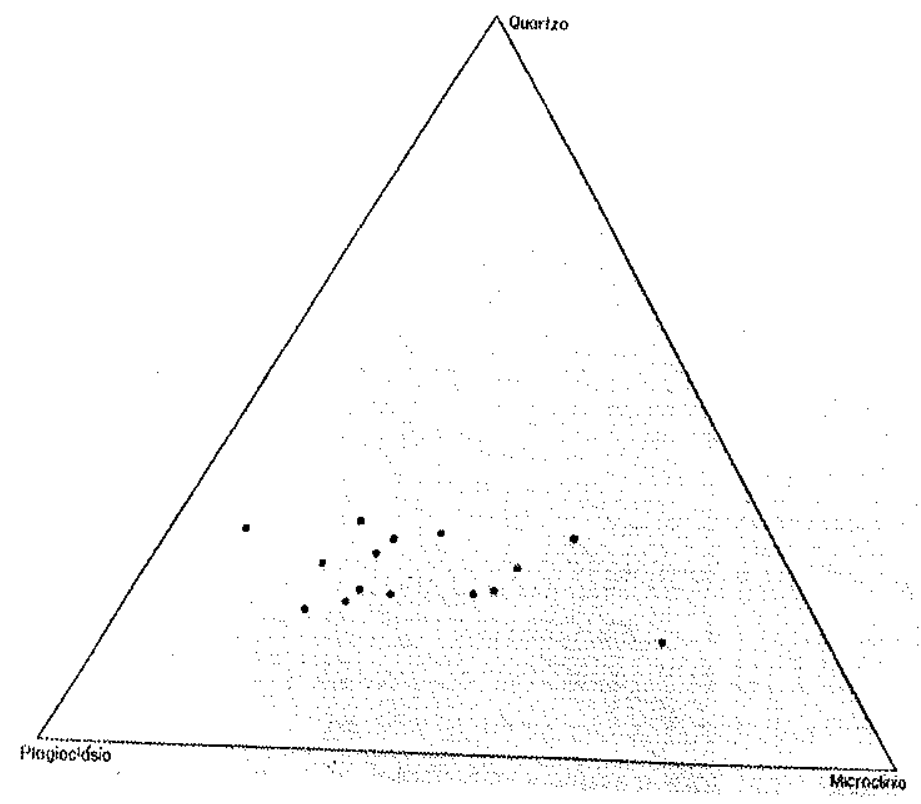

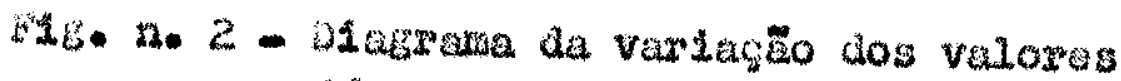
(it de volumo) do quartzo, plagtom ciesto o macrocilnto, nas pochas gratsultous. 


\section{PEGMATITOS}

a. Turmalina Granitos e Pegmatitos Turmelinfferos.

Ao Iongo do contato norte do granito Cantaroira a florem zonas poginatiticas ricass de turmalina passando localmente a grenitos turmalinfferos.

Estas faixas de espessuras e comprimentos varíveis ostão orientadas, no geral, paralelamente aos xistos e filitos. As espessuras méxinas não excedem elgumas dezenas de metros e nestas zonas se desenvolvem grenitos leucocráticos, ricos en turmalina, com curiosas estruturas de fluxo.

Nas faimas mais posemintes, os granitos turmalinfle ros e pegmatitos podem cortar discordentomente os xistos, was no geral são pralolos o no contato existe uria alternância de xistos e pegmatitos. Nos locais onde existo esta altornência de xistos e frixas pegnatíticas, ostas diminuem de espcssura a modida que so afastain do contato com o grenito.

A principalrente nas faixas pegmatíticas menos espêsass que se tornem mis claras as relaçõcs entre xistos e a Lácies pegmatitica.

o pegmetito acompanha os planos de xistosidade. No xisto, nas proximidades do contato, a rocha está impregnada do cristais de felaspato e prismas de turmelina preta, de pou cos millmetros de comprimento, orientados peralelernento a xistosidnde. O contato com a zona pegmatiticn não é brusco. observe-se numento no tcor e tmmanho dos foldspatos, que al cancem conprimento superior a $2 \mathrm{~cm}$. Dos minerais, ne faixa pegmat1tice, os mais abundentos são: feldspatos, quertio, turmalina e em pequena quantidado granada o inuscovita, está localinente mais abundanto.

Os felaspatos existentes s̃̃o microcínio e plagioclásio o nas zonas pegmatitices delgadas exibem as mesmas re laçõos paragenbticas que nos granitos, com evidentes sinais do substituição do plagioclásio sericitizado por microclínio.

Q guertzo, com cisalhamento menos intenso que nos gronitos, Às vêzes, contém inclusão do proprio mineral, șem continuidade optica, indicando ter havido recristelização. 
A turalina ef rroüentewente poiquilftica, con in clusões de guartio e nos prisnos miores, en seções basais, Hostra zunomento na colorne\%o, sencione parte interna azul esverdeado e nas bordas castanho-esverdeado (schorilta?).

Hr: Perus, $\approx W$ de f́rea estudada, tembém na zona do contuto do granito Cantrireire e zistos, eflorail grandes zonas pegmatbides a granitos turisinfraros com astrenhas feiçôs de estruturas de fluxo, locelmente ricos de lepidolita, thesui, 1963). Nesta região os plagioclésios são mais sobicos o não apresentam os marcantes sinais de substituiçôno polo aicroclinio.

Na região de São Roque, Coutinho (1953) menciona tar a turmalina ausente nos granitos e abundante em aplitos e pegmetitos.

A ocorrência de turmalina em zonas pegmatiticas, ao longo do contato norte do granito Cantareira, na Erea estucla da e eni aplitos e peginatitos na região de fão Roçue, indica ter este mineral se formado num estágio tardio da evolução dêstès corpos granficicos.

Rankama e Sahama (1250) menctonam o alto teor de boro em sedimentos marinhos. Admitem a possibilidade de que o boro, presantem zonas de contato de rochas sedimentares com intusões granfticas, estaria orichinalmente presente nos sedimentos e posteriormente concentrado nas proximidades do contato do granito, como resultado de sua grande mobilidade.

Barsukov (1961) no estudo sobre a geogulmica do bo ro observou que en ańlisgs da mesma rocha, contendo plagio clásios sericitizados en intensidades variáveis, havia decrés cimo progressivo no teor de boro com o aumento na intensidade de sericitização. Como a turmalina es em nuitas roches gra nitbides um mineral tardio, admite este Autor que as turmali nas tenham se formado como resultado da libertaça do boro dos plagioclésios durante o processo da sericitização em con dições de atividade hidroterinal, associada ao netassomatismo. 1 improvável, para a área ora em apręço; que todo o boro Ii bertado, durante a sexicitizaño don plagioclásjos, seja res ponsável pela formação de tuxmalinas en pequenas áreas res- 
tritas aos granitos e pegmatitos turmalinfferos.

Se fôr comum a observação de Ligitiskyn e Khitrov (1952) de que epidoto pode ser enriquecido em boro durante a epidotização, bastante provável que parte do boro libertado, durante a sericitização dos plagioclásios, tenha sido in corporadw ao epfooto, frotente nos plagioclásios sericitigados e junto com biotita.

Os pegmatitos turnaliniferos e turmalina granitos representando a fase final da atividade magmática, são mais um dado a favor do metassomátismo dos granitos ter-se dado na fase pneumatolitica-hidrotermal, como proposto par Fslsola (1956).

b. Pegmatitos e Aplitos

Os granitos Cantareira e Matriporã são ricos em aplitos, pegmatitos e zonas pegnatoides. Os aplitos, de peque na espessura, cortam os granitos seguindo planos mais ou me nos regulares e são constituidos essencialmente de quartzo e feldspatos. Iño foram observados aplitios ricos em turmalina, como os descritos na região de são roque, por Coutinho (1953).

os pegmatitos e zonas pegmatbides fornaun corpos ta builares ou de forma Irregular, cortando granitos e encaixantes. A forma relacões de campo sugerem que pegmatitos originaram-se por mais de un processo:

2. Pegmatitos aparentemente intrusivos:-

Possuem espessuras, no geral, inferiores a 1 metro e são constituidos de quartzo, feldspatos, biotita, muscovita e turmalina, com cristai de tamanho centimétrico. No geral, on contatos con os granitos são nftiaos e são comuns variações de direção e mergralho, ao longo de um mesmo corgo pegmatítico. (foto $n \cdot 8)$

2. Pegmatitos o zonas pegmatoides de substituição:-

Possuem formas variadas, geralmente constituindo zo. nas pegmatoides irregulares, com contatos de transição pera - granito. A comum a orientação das bjotitas no granito es- 


\section{XISTOS GRAUTTIZADOS}

Em duas áreas nass vrominidades do contato SE do granito Cantireira e noutra no contato NE do mesmo granito, os ristos foram granitizados, originando lentes de para必gráisses, sendo a melnor exposicão a que șe looaliza na Poareira coteca, no municílio de Guanulus. Juesta ocomência, os filitos pessam graduamente a xistos, onde aparecom zom nes feldspatizadas, com pequenos porfiroblastos, ao lonso do acamamento. Gamadas feldspatizadas altemam-se com outras sen feldspatizagão. Os feldspatos aumentian en ta manto e Prequência à proporção que se caminha para a área contral nais granjtizada.

Na parte contral a estrutura anterior da rocha é bem conservada. Camades granitizadas de paragnáisses altex nam-so repetidamente com camadas de homfels, formados pro vavelmente a partir de rochas carbonatadas impuras e delga das omadas de quartzitos. As camadas de homfels variam na espessura desde poveos centŕmetros até superiores a $2 \mathrm{~m}$. A segunda ocorrôncia, também om forma de, Lente, é coxtada pela via Femão Dias, na altura do $15 n .554$. A estru tura dos xistos anteriones à granitizaça está, conservada, rnas rão de modo tão marcaute, como na antertor.

A terceira ároa, no conteto ISE do granito Cantarej ra é un projongamento dêste corpo granítico. Também nosta ocorrência nota-se, tento no sentido porponaiculax como ao Ionso da estrutura dos xistos, em direção ao como erranitico um aumonto sradual no tamanho e frequênoia dos feldspatos.

Ista foldspatização seletiva o aunenta nas cana das metassedimentares originalmento psamíticas.

A orientação das biotitas é parelela com a estrutura dos xiatos $\mathrm{e}$ mesmo nas, zonas onde a sranitização roi mais intensa, estão conservados vestígios da eatmutura original dos xistos, eparecendo agora como faixas mais ricas em biotita, altemadas com outras rioas em feldspatos, especial mentio sob forma de porfiroblastos.

Na ocorrencia da Pedreira Coteca, os xistos finos nãa feldspatizados são constitúlos egsencialmento de quartzo, biotita e muscovita e subordinademen/epidoto e cloxita. os grãos de quartzo não apresentam extinção ondu- 
lante e são de tananzo uniforme. Altermamme delgadas len tes ricas em quartzo com outras ricas em biotitu.

A biotita é parda e pode alterar-se par. clorita, geralmente da varijedade penina. Associado. d biotita ocorre comumente evídoto.

Tras camadas com inficio de feldspotizaçao o primei ro leldspato a se desenvolver é o oligocísio. Inicialmente é xenomorfo o depois forma porfiroblastos com tamanio su perior a $0,5 \mathrm{~cm}$, onde o comprimento maior, no geral, não cojncide com a xistosidado. As placas de biotita aumentam no tamanho e estão frequentemente cioritizadas. Porfiroblas tos de srenadas englobam palinetas de biotita e grãos de quartzo. Poxíizobjastos de plagioclásio deslocam lateralmen the os demais minerais da roche.

Com o aumento na intensidade de feldspatização fox. manmse porfiroblastos de mioroolínio englobardo os deneis mi norais da rocha, inclusive, nos matoros, os porfiroblastos do plagjoclásio.

As relacooos paragenéttcas do microclínio são semeLuantos às descritas para os granitos.

Entre as places de biotjta, os gräos de epidoto aumentam en núnero e tamanho e comumente forman onvójucro ae oristais de allanita metamítica. Parte de biotita astá alte rada vare muscovita e clorita, Iibertando $110_{2}$ que, en microgrânulos de Loucoxenjo, rodeja a biotita. Ho tes microgrânuIos de lencoxônio são os responó́veia pela fumação de tita nita, que, em cristais iajoblésticos, aumenta em rrequêcoia - tamanho com a alteração das biotitas.

Ividencias de que a titandta comou-ge a partir do Leucoxênlo são as inclusões, nob oxistais malores, de bio tita, apatita, opldoto e opacos.

Grânuios de zircäo existentes nas biotitas dos xis tos continuam nas comadas feldspatizadas o formam fortes ha3os pleocróicos na biotita. A forma conum é prismática, mas excepcionalmente aparecem sol corma de bipirâmido.

Nes zonas atuajmente fomadas por paragmádsaen, os porfiroblastos de plagiocjásio e microclinio chegan ultrapas sar $2 \mathrm{~cm}$ de comprimento a no oligoclásio podom ocoxrer zonas onde ge injoia a microolfnizaçäo. Nestes paraguéssos, oo delgados leitos de quartajto são constitufdos essencialmento de quartzo, com extinçao ondulante gräos intimamente su turados. Mos quartzitos e localmente nos paragnáisses ocor- 
re tumalina (schorita ?) com pleocrolsmo: E (vermelho-vio leta) e 0 (vorde-escuro), às vêzes, com inclusós de epfao to a biotita. A apatíta aumenta tambóm em trequexicia o tamano nas zonas mais granitizadas aparocendo sob forma do prismas idioblásticos, orde om alguns'se notam, nas seoçoos prismáticas, zonas intomas de ploocrofsmo acentuado: E(castanhoescuro) o o (castanho-amarelado).

Yela descrição acima notamo que a composição mineral dos xistos sranitizados é somelhanto à dos granitos. Na transformação dos biotita xistos, constitufaos essencial mente de biotita, quartzo, muscovita e clorita, para paragnáisses houve adição principalmonte de $\mathrm{K}$, Ca o iٓa.

- grau de metanorfismo dos wistos e filitos rão feldspatizados em zonas vizinhas aos feldspatizados indica que não houve grande eumento na intonsidade de metamoriamo. Altás, segundo Bolousor (1962), não é o aumonto da temporatul ra o fator principal na fomação de rochas granitótaes, mas stm a ação de soluções mineralizentes móveis e ativas. Estas soluções levam à formação de eraniţos em 'Iugares onde previen mente existiam rochas edimentares.

A observação le que a intensidade da feldspatização varia rá jorizontal, perpendicularmente à estrutura dos xistos e Uniforme na vertical, ou seja paralelemente à esm trutura, Indica que o movimento ascendente das soluçôs minoralizadoras, originado em níveis inferiores, percolou ao longo das estruturas majs favoréveis.

No paragnáisse dea área NE do granito Cantareina, as soluçoes foram mais ativas nas proximidades do contato, observando-se diminuição da intensidade de fejdspatizaça so longo da direção dos xistos, a medida que se afastam do granito. A semelnança entre a composição mineral e paragênese dos relaspatos dos sranitos e xistos grenitizados suge re que, provavelmente, estas zonas granitizadas representam partes superiores lateraí do batólito granitico da Cantro reira.

A favor desta hipótese devo ser mencionado que "jinjeçoos" disseminadas são provàvelmente o estágio inicial na formação de batólitos (Beloussov, 1962), nos quais estan injeções de material magmático granitizam os estratos da crôsta. Esta interpretação é apotada no fato de migmatiza ção ocorrer abundantomerite em zonas vizinhas aos batólitos, de modo a haver ume transigño: desde injeçoos disseminadas 
de migmatitos até enormes batóljtos. Istas injecōós disseminadas inciuem rocias granitóides, pegmatitos a gmatos gná1.sjocos (Belousov, 2962).

Deve ser também mencionado que a semelhanca na composição mineral dos paragnáisses e os xenólitos dentro dos granitos, ambos originalmente xistos, permite supor: que, provivelinente, un mesno mecanismo - acão de soluçóes móvejs e ativas, ricas principanente em Is e ITa - possibi J Ltaram o desenvolvimento de identicas associacoos minera lógicas:

o baixo grau de metamorfismo dos xi.stos, dentro da fácies evídotomanfibolito, permite conciuir que não só os paragnáisses, mas também os sranitos, formaram-so em comperaturas moderadas. 


\section{HORNETIS}

Nos granitos Cantareire e Mairiporã e também nos xistos grantizados na Érea SE do mapa, rochas metassedimentares passaram a hornfels.

Os mais abundantes são os representados por horn fels pelýticos e em menor proporsão psamiticos, alem dos derivados de rochas carbonatadas impuras.

\section{a. Hornfels pelfticos}

Algumas ocorrências jâ foram descritas por outros Autores. Móraes Rêgo e Souza Santos (1938) citam concentram cooes escuras, xistosds, formadas principaimente de quartzo biotita e en pequena proporção plagioclásio e microclínio, co. mo sendo "schlieren", com aspecto de xisto, semelhentes aos das encaixantes. Franco (1958) no estudo das rochas termomem tamórficas da série São Roque, descreveu vários tipos de hornfels, que afloram na Pedreira Cantareira, na parte sul da serra da Cantareira. Os hornfels descritos por Franco são principaimente biotita-hornfels, quartzo-hornfels e cálcio-slica hornfels, existentes dentro do granito e que seriam, segundo êste Autor, resultado da recristalização de rochas metassedimentares pelfticas, psamficas e rochas calcárias in puras, na fácies de piroxênio-hornfels, de Eskola.

Nos granitos Mairiporã e Cantareira são comuns xenolitos centimétricos e até de vários metros e no granito Cantareira afloram zonas de xistos ocupando, em área, vários quilometros quadrados:

Os xenblitos menores, constituidos de metassedimen tos, sofreram não só metamorfismo, mas tamberm metassomatismo. Alguns exibem estmutura palimpséstica, altemando-se faixas mais micaceas con outras quartzo-feldspáticas (foto $n 2$ ), São blotita-hornfels e os minerais são os mesmos do granito. Nas falxas escuras prodominam biotita e mascovita e nas mais elaras, quartzo e feldspetos.

As vêzes, alternam-se também estratọ de granula ̧ão fina com outros de granulação mais grossa. Nêstes, os de 
granulação fina, alem de quartzo, plagioclásio e micas, apre sentam grãos de epldoto, com tamanho superior aos demais minerais. Nos de granulação mais grossa, os plagioclásios, com composição An 28-30, mostram tendência jaioblástica. Comum ef também a formação de microclínio, desde xenomorfo, na massa da rocha ou sob forma de porfiroblastos que podem ultrapassar $3 \mathrm{~cm}$ de comprimento.

Os plagioclásios, quando associados a microclínio, sugerem pertencer a duas gerações diferentes. Nos da primeira geração, epídoto e sericita são comuns. Sua origem deve-se, ou d existência de plagioclástos no sẹdimento original, ou a formação posterior, pelo metamorfismo. Os da segunda geração, sem alterações e com tendência a formarem idioblaștos, predo minam nas proximidades dos contatos com o granito.

As relações paragenéticas do microclínio e plagiom clésios sericitizados são similares ès descritas para os gra nitos.

Também a ocorrêncla de biotita verde, ìs vêzes clo ritizada, com Itbertação de $\mathrm{TiO}_{2}$, 6 similar a dos granitos. similares são também os aceasbrios, como titanita, apatita e allanita.

\section{b. Hornfels psemiticos}

Foram observadas, nos granitos, várias inclusões decimétricas, constituidas de horntels psamiticos, originadaa, provavelmente, a pertir de sedimentos quartzo-feldspáticos. Petrogrelicamonte são constituidos essencialmente de quartzo, oligoclásio, microclinio o pequena porcentagem de biotita.

blástio

0 microcilnio 6 sempre xenomorfo, ao passo que 0 oligoclásịo, às vêreg, apresenta contôrnos com tendência idi obléstica. Os plagioclásios bastante sericitizados e antecederam o microclinto. Hste engloba tamben plagjoclásios alterados a não foram observados porfiroblastos.

\section{c. Zonas de xistos no granito Cantareira}

No maya gool6glco são demarcadas numerosas áreas 
de xistosno granito Cantareira. Nestes xistos a intensidade do metamorfismo de contato situa-se na mesna fécies que a do bs hornfels pel1ticos de pequenas dimensôes, mas a infuência metassomatica 6 menor ou quase ausente. As associacões mineralogicas nowtos $x$ istos asseme 1 ham-se mais ds representantes de metamorfismo regional, gue de metamorfismo de contato, prò priemente dito.

As associaçōes mais intoressantes. sĩo de quartzo, biotita, mocovita, granada (almendina?), sillimanita, pla gioclésio e turmalina.

Granadas, em cristais idioblásticos, englobem quart zo e biotita. A silimanita (fibrolita) ocorre como conjuntọ de acículas dispersas principalmente ne muscovita e quertzo. Wsta associąz̃o oparece bem desenvolvida, entre outras, numa zona de xistos nas proximidades do $\mathrm{km} 5^{4 / 3}$ da via Fernão Dias, nas proximidades de entrade sul do tunel.

Existem zonas de xistos nas quais podem faltar era nada e plagioclésio ou sillimnnita, outres são ricns em turmalina, formando verdadeiro turmalina xistos, evidenciando ecentura ação pneumatolítica.

ĩo geral a biotita é parda e nas áreas menores de xistos, por ação de atividade hidrotermal, mostro vírias lases de cloritização, que se 1 rudfa com a libertaça de Tio.*

A associação mineralógica destas zonas de xistos sugere a sub-fácies siliimanita-almandina-muscovita, da fácies almandina-anfibolito (Turner, 1960).

d. Biotita-horntels, no contato do granito Cantareira

Em aponas um afioramento fol observado o contato direto e fresco dos xistos com o granito Cantareira. Acha- So nas proximidades da cidade de Mairiporã, no contato norte do granito Cantareira, na Pedroira Cantareira.

o contato com o granito e paralelo à xistosidade e os xistos são ricos em crenulacões e cortadós por muito pegmatitos irregulares, às vôges, paralelos à xistosidade.

Nos xistos nota-se uma alternância de leitos de xistos e de material granfitico, com aspecto de verdadeiros migmatitos. 
A biotita possui pleocrolsmo: X (amarelo-palha) e 2 (castanho-avermelhedo), $N_{y}=1,635$, sugerindo abundância de $\mathrm{TiO}_{2} e$, as vêzes, está alterada para muscovita. "

Esta 6 menos abundante que a biotita e. frequente mente possui inclusões aciculares de sillimanita. o plagioclá sio, albita-oligoclásio, G fresco, som tendência idioblésti ca o poiquiloblástica, podendo conter inclusões de sillimani ta, quartzo e micas. o quartzo está commente fraturado e com extinçẽo ondulante. Os gxãos de zircão, inclusos nas bio titas, formam fortes halos ploocroicos o em pequena quantida de ocorrem turmalina, epatita e opecos.

tate xisto do contato difere dos xenblitos de xistos, no granito, pela presença de biotita castanho-avermelhada, plagioclásio mais sódico, ausência de epídoto e titanita. A ausênoia de feldspato potássico e de alteraçõcs nas biotitas sugere que, neste local, não atuaram metassomatismo o atividade hidrotermal.

\section{e. Hornfeis Cálcio-Silicatado}

Junto ao contato norte do granito Cantareira, nais proximidades da Pedreira Cantareira, intercalado nos xistos, aflora um hornfels de rochas célcio-silicatadas.

A espessura é de poucos metros, não tendo sido pos sivel determinar o comprimento. Hste hornfels mostra nftida origem metassedimentar, com alternância ritmica de estratos claros e outros com coloraç̃o cinza-esverdeada. Normalmente a grenulação da rocha é fina, sub-milimétrica, mas locelmente, por ação do metamorfismo e metassomatịmo, a recristaliza ção originou cristais quase centimétricos.

Nos eatratos mais claros predominam, quartzo o plaw gioclásio sbdico e subordinadamente anfibblio. Nos mais escu ros note-se nftida predominchcia do anfibólio, da série tremolitamactinolita, com fraco pleocrolsmo: $\mathrm{Z}$ (incolor) i Z (a marelo-esverdeado), $\mathrm{c} / \mathrm{z}-162$ e $\mathbb{N}_{\mathrm{x}}-1,62$ e $\mathbb{N}_{\mathrm{z}}=1,64$,

En pequenas zonas Irregriares, onde a rocha tariberm sofreu ação do metassomatismo, o anfibólio, com quase $1 \mathrm{~cm}$ do comprimento, of normalmente poiquiloblástico e crivedo de inclusões de plagioclásio e quartzo. 
$-58$

Comum tambẹm é a ocorrência de grênulos de zircẽe dentro dos anfibólios.

Q. plagioclásio 6 poigujiobíntion y englobendo pris mas de anfibólio e quartzo. Nestas zonas, alem an recristali zação dos minerais existentes, desenvolveu-se também feldspa to potésico.

Wiste, de forma irregular, englobando os outros mjnerais da rocha, não apredenta a característica geninaça do microcínio, mas apenas extinção ondulante. No entanto, em porfinoblastos de plagioclésio notam-se, no seu interior, zo nas de microclinização, onde a gemina ão en grade está presonte.

Cordani et al. (1963) no estudo de rochas calcio- silicatadas da região de Rerus, tembém no contato norte do grenito Cantareira, descrevem rochan algo similares com as ora descritas, que localmente, alem do anfibolio, possuom djopalaio.

Sogundo os Autores mencionados, estas roches "teriam sịo intẹcalaçôes de calcários magnesianos impuros" en tre os xistos.

Para o hornfels ora descrito, com alternância de estrato ricos om cuartzo foldspetos e outros mais ricos om anfibólio; além da ocorrência de numerosos grãos de zircão, \& provável que a rocha original tenha sido um sẹimento bibrido, formado por contribuição cléstica e química.

hibnoo?

afe. nagoráal 


\section{VII - TECTONICA}

\section{MUEOTOSOS E SIMBOLOGIA}

O estudo dos elementos geométricos estruturais nos granitos e rochas anteriores é baseado em duas tecnicas:

a) Representação no mapa geol Ggico das diferentes unidades li tológicas e suas atitudes.

b) Istudo estatistico dos elementos estruturais liagtados no campo. Para a projeção dos elementos estrutura1s foi usado o hemisfério infexior, do diagrama de schmidt ("igual area").

Superfícies S- Estruturas planares nas rochas metassedimen tares, $\underline{S}_{1}=$ acamamento, $\underline{S}_{2}-$ clivacem de fratura. Foliação - Estmutura laminada resultante da segregação de di ferentes minerais, em estratos paralelos à xistosi dade. Nos metassedinentos a foliação quase sempre coincide com o acamamento, o que levou ao desenvol vimento de uma xistosidade de acamamento (bedding schistosity). Ségundo De sitter (1956), êste tipo de xistosidade é devido, provàvelmente, à recrista lizạão ao longo de planos de deslizamento, parale los ao acamamento.

Para os granitos considerame como foliação a orim entaça paralela de minerais tabulares - micas (Turner e Weiss, 1963, p. 353).

Inineamento - A adotado o conceito de Cloos. (1948), como sendo um têrmo descritivo, não genético, para estrutux ras lineares, dentro ou sôbre a rocha. A simbolo gria usada ef a recomendada por Tumer e Weiss (1963) designando-se os elementos lineares por $I_{1}, I_{2}$.

Eixo de dobra - $\underline{B}$.

Dobras longitudinais - Eixos paralelos ao alongamento regional do corpo orogenético.

Dobras oblíquas - Dobras com eixos orientados perpendicularmente ou obliquamente às dobras longitudinais. 


\section{ESTRUTURAS NOS METASSEDIMENTOS}

Como ja foi mencionado no capítulo IV, o acamamento nos metassedimentos está, no geral, bem consemado. Os ca racteres que sugerem que se trata realmente de acamamento sฉ̃o:

a) continuidade Iitol6gica ao longo do plano da camada.

b) presença de estruturas sedimentares, como sejam, variação na granulação, acamamento gradativo e, não raro, estratificação rítmica.

0 acamamento \& meihor conservado nos metassedimentos menos metamorfoseados e particularmente bem visivel nas rochas alteradas."

Com o dobramento regional, as dobras foram alinhadas na direção NE-SW, constante para a serie São Roque, em todo - Estado de são Paulo. Na área estudada, as dobras Iongitudinais de direção NE-SW apresentam caimento do eixo para $\mathrm{NE}$.

A fig. n. 3 apresenta o ảiágrama de contômos da projeção de polos de 400 superflcies $\underline{S}_{1}$, medidas nas encai xantes dos granitos. Na sua grande maioria predominam as di-

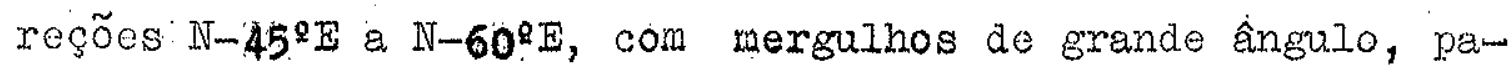
ra sul ou para norte.

As direções e caimentos do Iineamento $I_{1}$ (parale Ios a B), medidas nas encaixantes dos granitos, estão, na sua grande maioria, tambẹn orientados $\mathbb{N}-459 \mathrm{E}$, com caimento de 208 a 30 NE (rig. n. 4).

No entanto, na obșervação do mapa geológico, notase Erande variação na direção do acamamento, em zonas próximas aos contatos com os granitos e uma maior uniformidade nas zonas afastadas. Esta variação 6 partjcularmente conspi cua na área situada entre os granitos Cantareira e Mairiporã. Já foi mencionada a existência de acomodações das encaixantes, como resultado da colocação dca corpos graníti cos, bem como a ocoriência de microdobras e crenulações nas proximidades dos contatos.

Eebas acomodações nas encaixantes levaram à formação de um dobremento superinposto (dobras oblíquas), em esca 


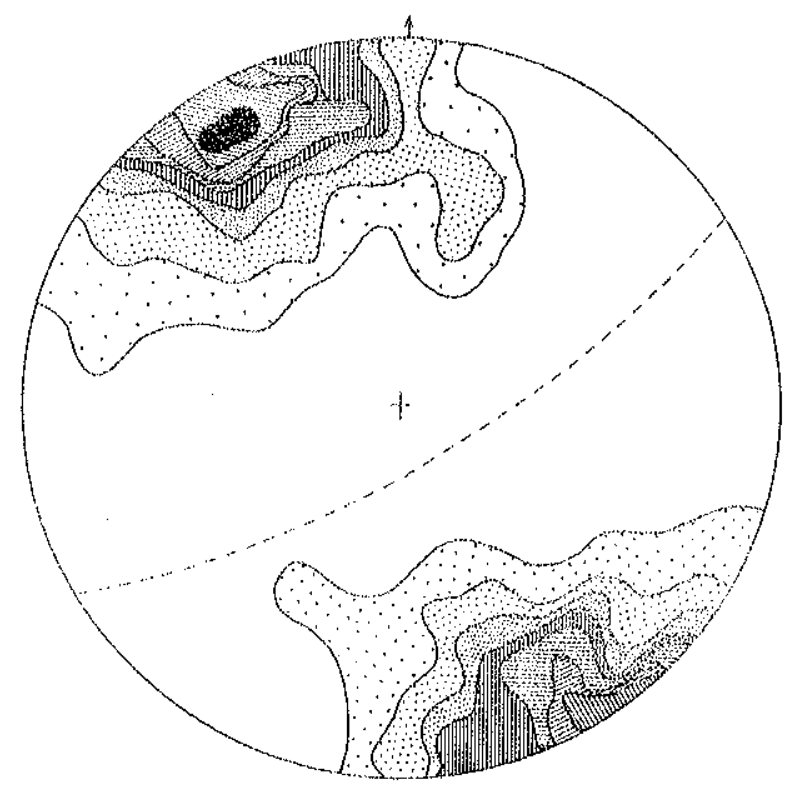

F1g. n. 3 - DLagrama de contôxnos da projeçäo de 400 superficles $\mathrm{S}_{1}$, medidas nas encalxantes dos granitos. $1 \%$ da área.

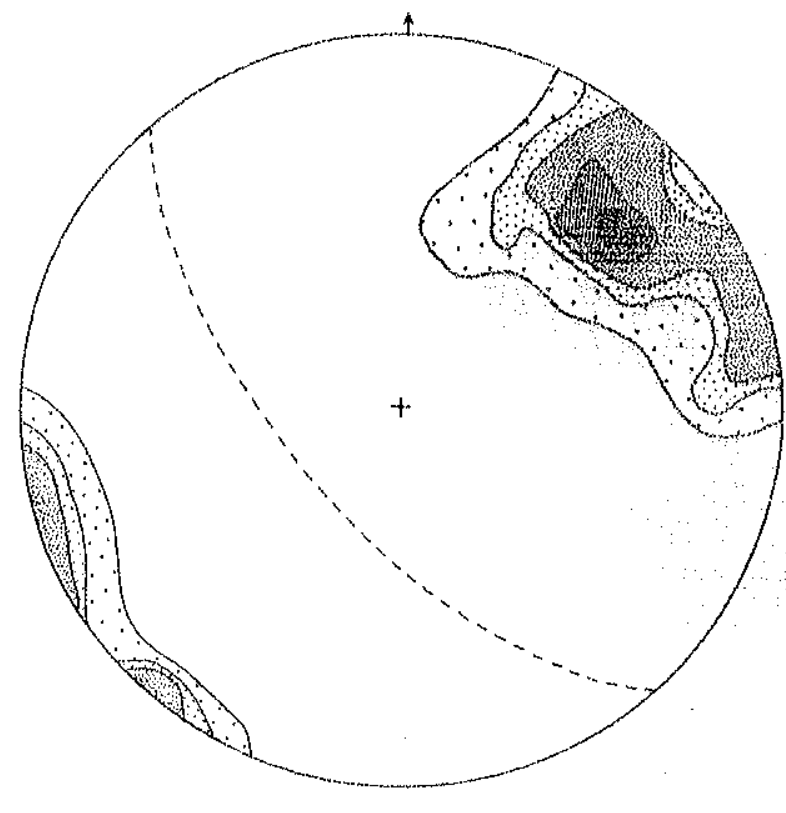

Fig. n. 4 - Diagrama de contôrnos da projeção de 100 Iineamentos $I$, paralelos a $B$, nedidos nas encaixantes dos grant tos. Conţôrnos de 12\%, 10\%, 8\%, 6\% e 4\% da area. 
las mesoscópica e mioroscópica, que se reflete tainbém na es cala megascópica.

Estas estruturas na escala megoscópica possuem ampljtudes, variáveis, desae pequenas crenulaçoes (fj.j. n. 5), passando a microdobras de amplitudes centimetricas (figs.no. 6 e 7) a decimetricas (foto n. I ) e caracterizam-se pela srande variação na atitude do caimento dos eixos das dobras, mesmo em pequenas distâncias.

Indicações da existềncia dêste dobramento superimpôsto (aobras oblfquas) estâu presentes não sb.nos dados apresentados no mapa geolbgico, mas também na formação de um novo lineamento $\mathrm{I}_{2}$ e clivagem de fratura $\mathrm{S}_{2}$.

ste novo lineamento, relativamente raro, ocorre nas dobras de escala mesoscópica (dobras obllquas) e achase orientado perpendicularmente aos eixos das dobras (B) e desenvolvido como resultado do deslizamento de uma camada sô bre outra.

$\mathrm{Na}$ ilg. n. 8 estão representadas as projeções dos polos e tragos de $s_{1}$ e o Iineamento $\underline{I}_{2}$. Apesar do pegueno nú mero de ojsexvaçõeș, nota-se a não concordância com o Iineam mento $I_{1}$ da $\mathrm{fig}_{\mathrm{g}}$ in. 4.

Além do lineamento $I_{2}$, ocasionalmente fol observada a existência de clivagem de fratura $\left(\underline{\mathbf{s}}_{2}\right)$ relacionada com o.segundo dobramento. O diagrama da fig. n. 9 apresenta as projecõos dos polos de $\underline{\underline{S}}_{1}$ - $\underline{S}_{2}$ e as interseções de $\underline{S}_{1}$ e $\underline{S}_{2}$. A linha formada pela intersecço dessas duas superficies ori gina um lineamento ajferente de $I_{I}$, tanto na ajreção como no caimento.

No diagrama da fig. n. 4, nos lineamentos $I_{1}$, apeșar de predominar a direção $N-4.5 \%$, notame grande variação na direça e também no caimento; indicando que o Iineamento $I_{1}$, não fol destruido durante o dobramento superimposto e representa a direção de $B$, nas dobras obllquas. O caimento de $I_{\text {I }}$ aumenta nas proxinidades dos contatos com os granitos, principalmente nas suas áreas terminais.

o paralelismo das zonas de xistos no granito Canta reira, com a estrutura regional, f facilmente observável no mapa geológico. A orientação do Iineamento $I_{1}$, destas zonas 

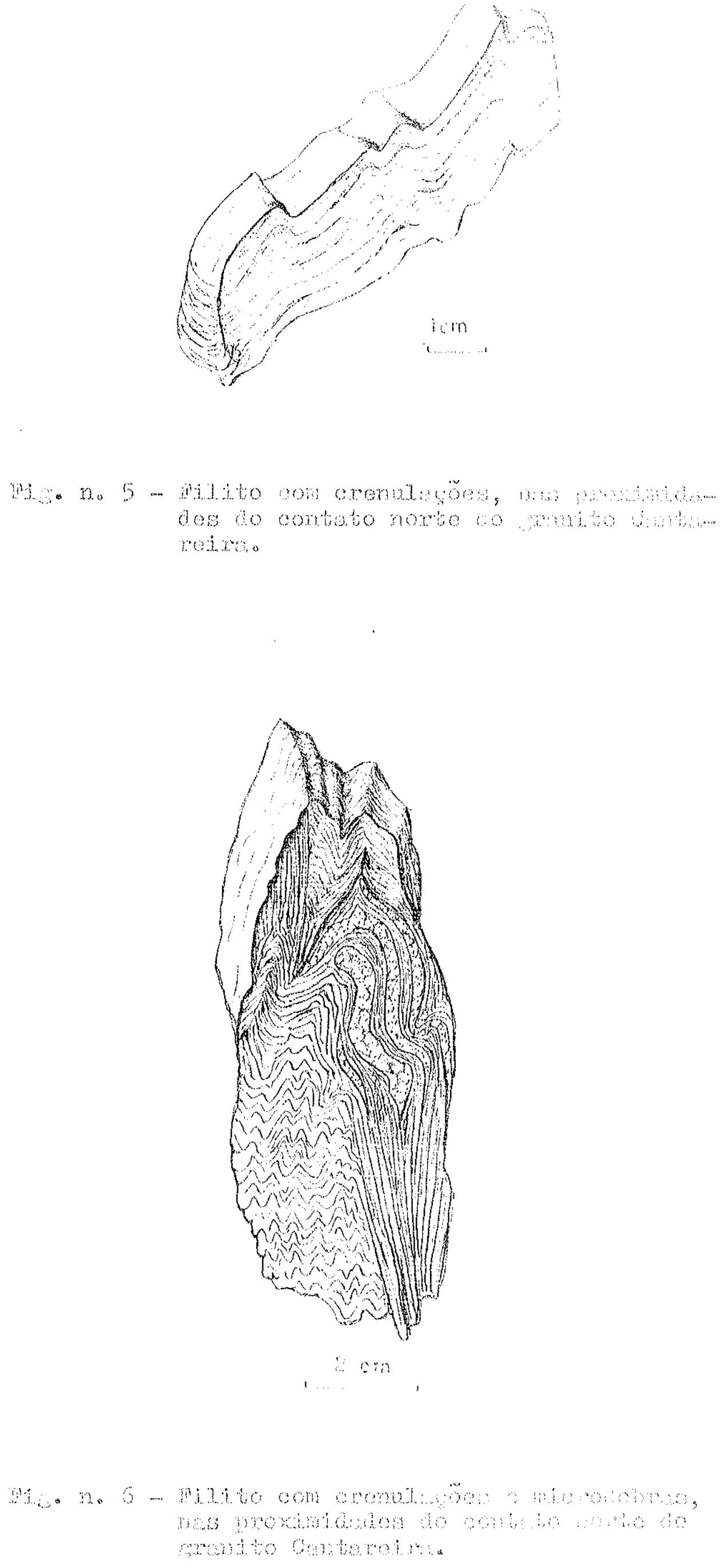


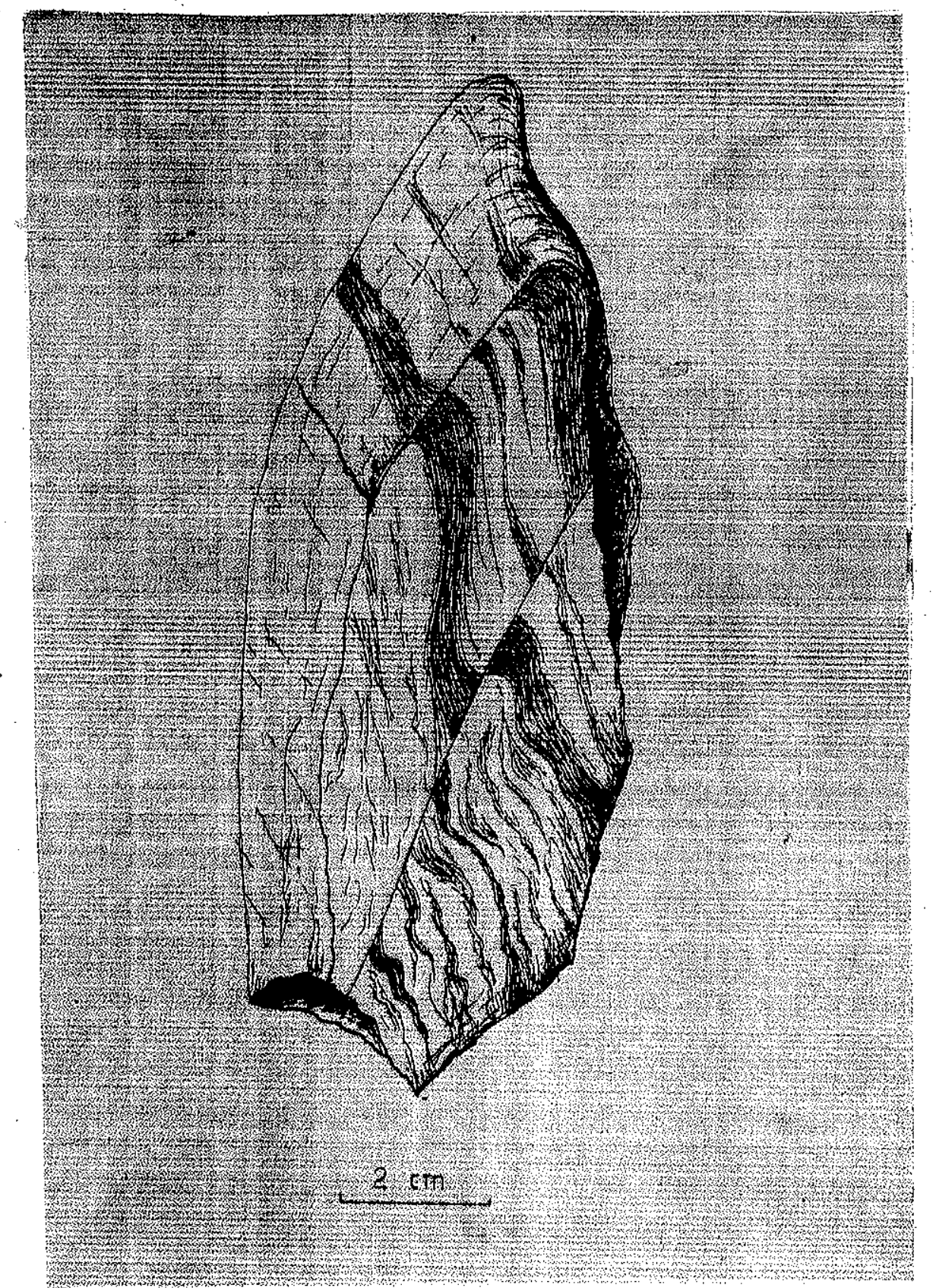

Fie. n. 7 - Filito com estrațicąão rítmica, apresentando microdobras e falha.

Proximidades do contato norte do granito Cantareira. 


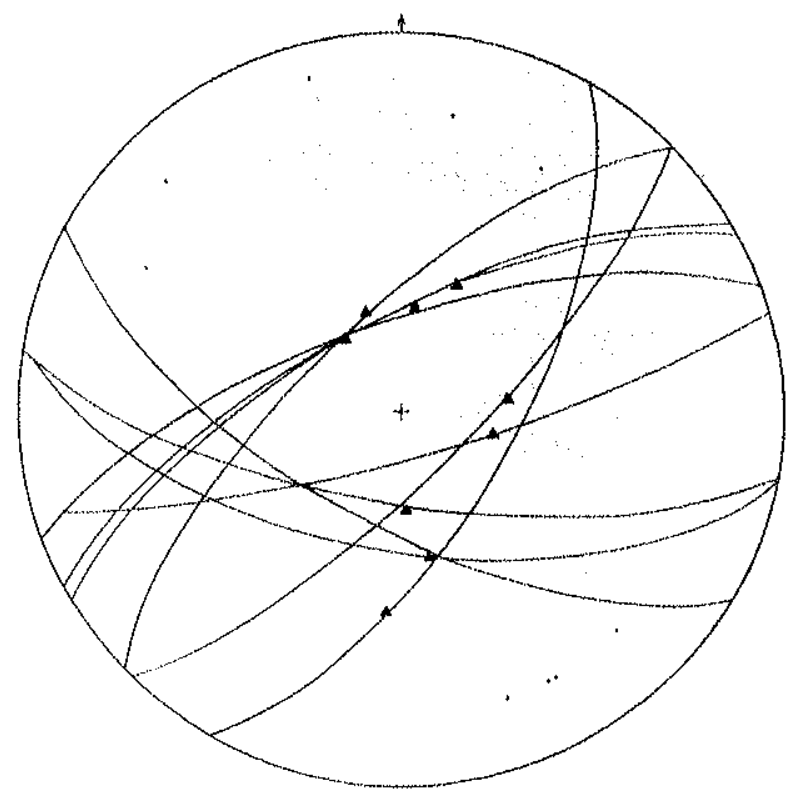

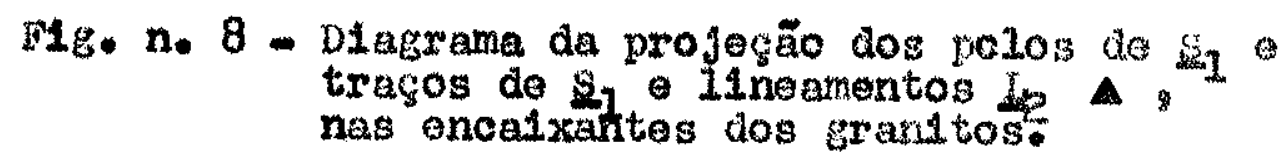

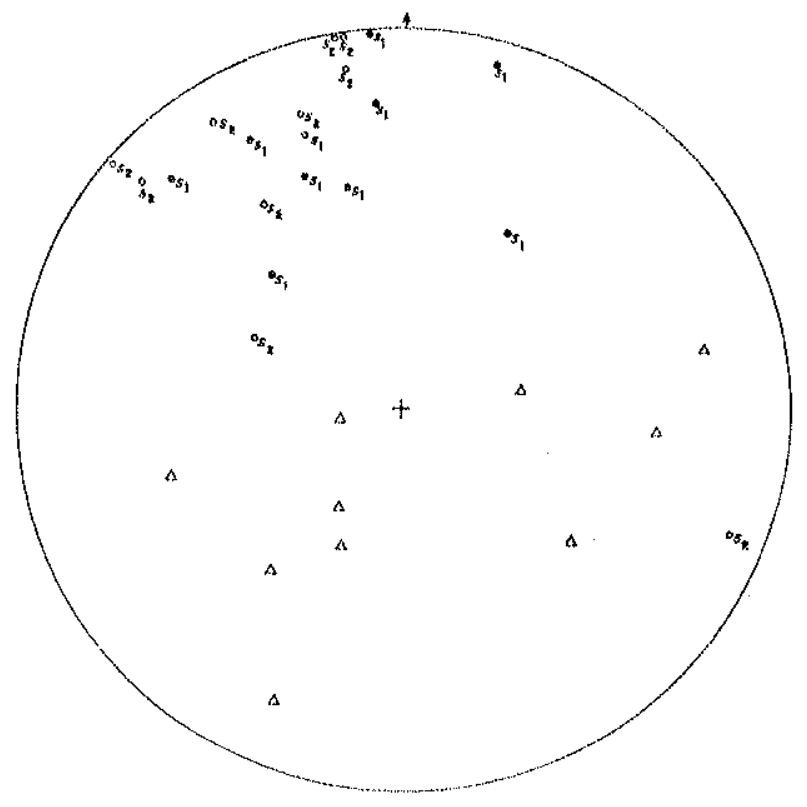

Fig. n. 9 - D1agrua da projocão dos polos do (acartanento) c.llvagem do etratura

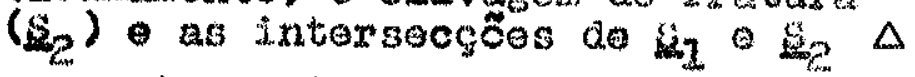
nos metaszedimentos. 


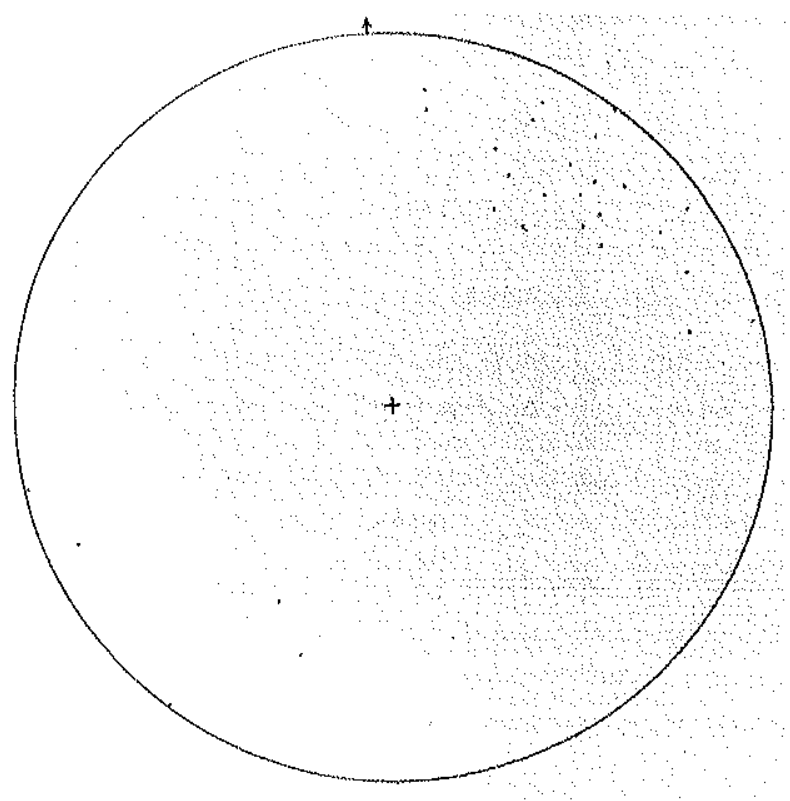

\section{F1g. n. 10 - Projeçōes de 27 IIneamentos $I_{1}$, dos $x 1$ stos conservados no granito Cantarelra.}

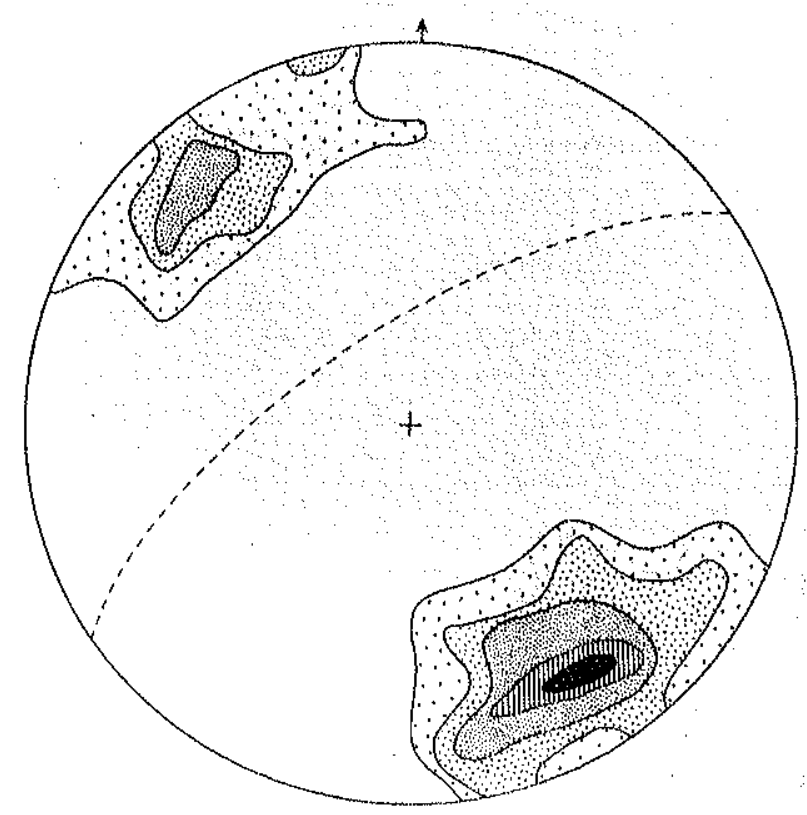

Flg. n. 11 - Diagrama de contôrnos da projeção de 100 planos de follacăo nos granitos. Conţornos de $15 \%, 10 \%, 8 \%, 6 \%$ e $4 \%$ da area. 
de xistor (fig. n. 10) também apresente paralejismo con o $3 . j$ neemento I predominente, nas encaixantes, con a estrutarn

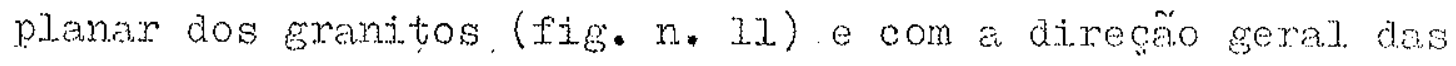
encaixantes (fjg, n. 3).

Esta uniformidade estuturel permite as seguntes conclusões:

1. - O dobraménto regional antecedeu a colocagão dos granitos. 2 - A colocaça dos corpos intmusivos, paralelmento a estru tuxa regional, com foliesấo paralela aos contatos, deu-se ainda durante a fase toctonjca.

3 - O dobramento superimposto, con formacão de dobras obléquas e desenvolvimento de $\underline{y}_{2}$ e $\underline{S}_{2}$, principalmente nas ro nes vizinhas aos corpos granfticos, deve-se de fase in ... tirusiva dos granitos.

4 - A conservacño des zonas de xistos e anfibolitos, em por sição paralela -diroç̃̃o e cainento - a estrutura pegio nal, indica que os corpos graniticos, principalmonte o granito Cantarejra, representam as partes suporiores dos corpos intrusivos.

\section{ESTRUTURAS NOS GRANITOS}

Nos granitos as feiçöes estruturais mais consprou aś são a foliação, diáclases e ralhamentos.

\section{a. Foljação}

Como jefoi mencionado, a foliação, representada pelo alinhamento das placas de biotita, 6 melhor deservolvida nas proximideides dos contatos con a encaixantes. Näo obstante, aparece tambern, com certa frequencia, nas virimaracas das ronas de xistos, dentro do grenito Canterejra.

Neste granito, que possui, não só a maior express̆o em érea, mas tamberm naior complexidede estruturel, a diroşzo da foliagẽo 6 , no geral, NE, paraleja ao contato com as en caixontes.

o mergulho da foliação, geralmente com ângulos su-.. periores a 609 , não 6 constante no ênegulo nem no sontido, ds 
veres, mesmo en pequenas distánciar. As causas da variacjo dus mergulhos da poliação deveñ̃o estar ligadas airebamente ao processo genético dos granitos.

Cono já foi alscutido no captútu referente a orisem dos sranitos, admite-se que êtes sejam sintectônicos. As sim, a estruture planar desenvolvida ainda em condicóos de tectonisino ativo, apresentando variaços no mergulho ... senti. do e ângulos - reflete, no sranito cantareira, a influência das rochas preexistentes, que foram assimiladas parcialmerte pelo mapa e também corrobora a hipótese de gue, na area es. tudada, o granito Cantareira representa a parte superjor do corpo intrusivo.

No granito Wairiporã, o mergulho da foliaģão, nọ contatos norte e sul, é para o interior do corpo intrusivo. Se estas atitudes refletirem a posiça do corpo grentítico, en profundidade, o mesmo terá forma lenticular.

Já no granito-graisse a toliagão, com mergulho para sul, paralela ds encaixantes, dá a êste corpo, pelo menos na área do mapa, forma de um sill.

No diagrama da $1 \mathrm{ig}$. n. 1.1, representando o diagraw ma de contomos da foliagẽo nos 3 corpos granticos, notamso - marcante paralelismo e concordancia com a estrutura das on caixantes, representada no diagrama da tig. n. 3 .

\$ possivel que a maior frequência dos merzul'os pa ra NW seja meramente acidental e se maior numero de observa... göes fosse possivel, haverie, provàvelmente, simetria na dis tribuigão dos contôxnos.

b. - Diéclases

Os djagramas de contôrmos das figs. ns. 12, I3 14 representam a distribuigão de diéclases nos 3 corpos era... nitioges.

O da fis. n. 12, totalizando 300 planos de dikelam sos, no granito Cantareira, principalnexte en sua porcão $\mathrm{NE}$, mostra 3 máximos de frequência de 6-8\%. O máximo no quadrante NW e o subraximo no quadrante SE referem-se a diácjases praticamente longitudinais (ou S, de Balk, 1948), pois 


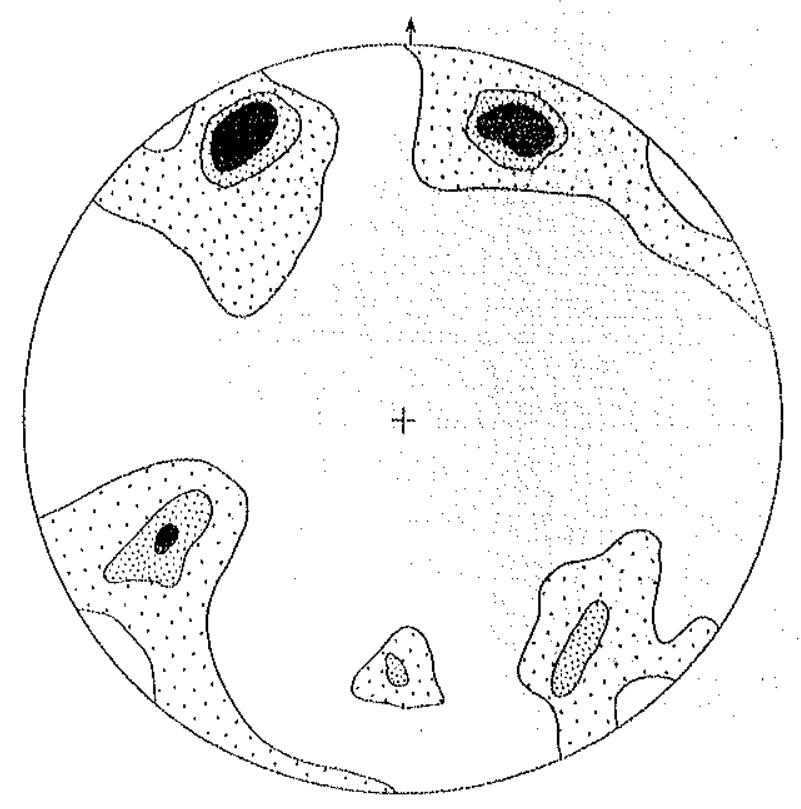

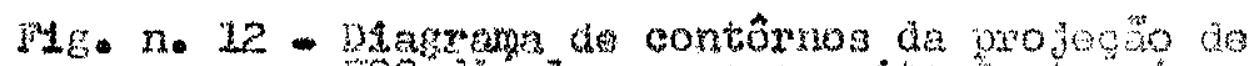

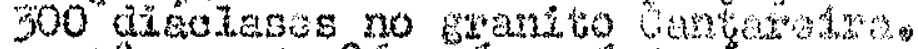

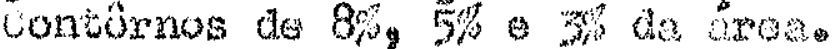

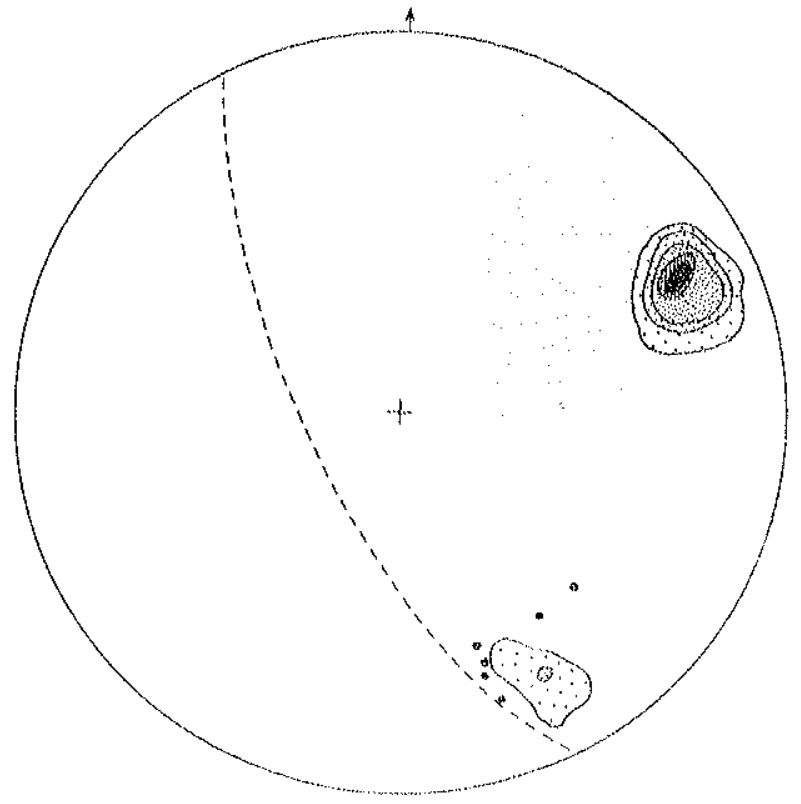

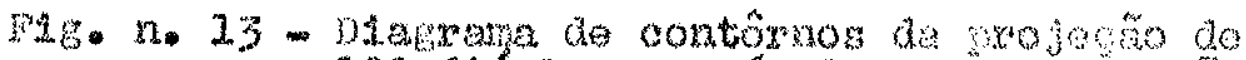

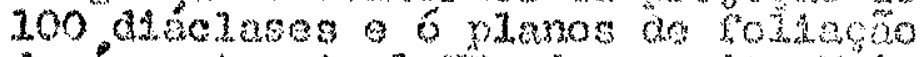

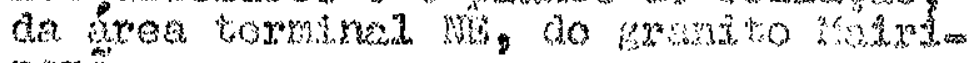
para. Contorsos ae $30 \%, 25 \%, 20 \%, 25 \%$ a $30 \%$ da sate 


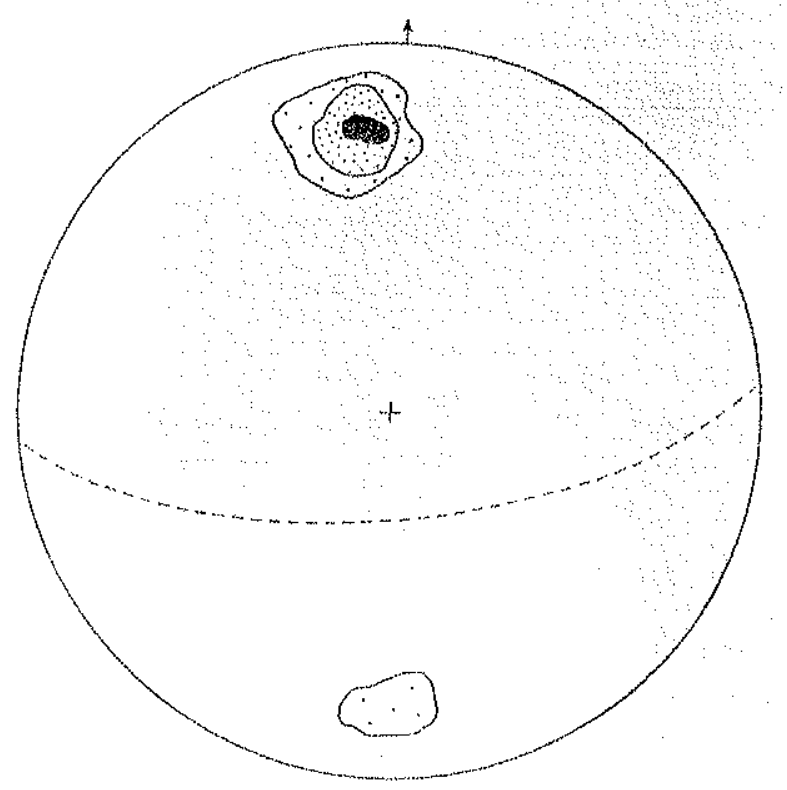

FLE. n. 1/4 - Dlagrama de contôrnos da projeçäo de

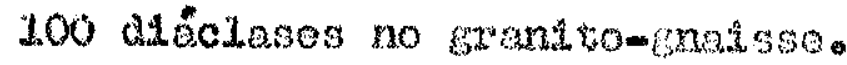

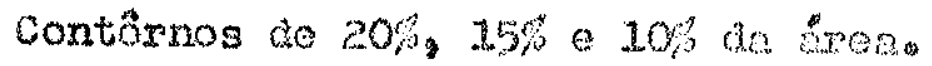


concordantes com e estrutura planer dos granitos. O outren méximo, no quadrante NM, apresenta diáclises diagonais.

o significado genético dos sistemas de juntas não poderé ser apjicado no sentido restrito, ds rochas consolida des diretamente a partir do magma, cono é usado por Balk, uma vez que, na sua formação, atuaram, aúm dos processos normais da consolidação do magme, também as forçs tectônicas regio nais contemporâness.

No entanto, pelo paralelismo entre a estrutura reGional o estrutura planax dos grenitos, 6 possivel que as ajaclases dissonais representem realmente planos de cisalhamento.

No granito laixiporã, o diagrama de contômos, da fig. n. 13, representa diaclasamentos na area terminal NB, do corpo grantitico. Predominam, na sua grande maioria, as juntes transversais ou de tensão, orientadas perpendicularmente à estrutura planar.

Na $\mathrm{fig}$. n. 14, representando as juntas no granito-gnásse, predominam as longitudinais. O intenso cissunamento neste granito, aliado d milonitização e lalhamentos paralelos estrutura do compo sranítico, sugexem aue estas juntas sejam realmente singensticas.

\section{c. Falhamentos}

Je Soi mencionado repetidas vernes que os eranitos foram deformados por açấo de esforgos tectônicos. Fstas deformacoos provocaram cisalhanentos nos ninexis e deslocenentos ao longo de patanos de felhas.

o cissihamento está presente en todos os cranitos, se bom que a intensidede nem sempre e unifome. Fomalnente 6 mais acentuado nas zonas termineis e contatos com as encaixantes. No granito-gnátisse, nétrea terminal representada no mapa geolóstco, o cisathame: . . ....t. nularmente ben acentua do, ao longo de vários qujzometros, o que imprimiu à rocha astrutura de "flaser". A acão dos esforços levou também formaçro de numeroses zonas miloníticas e de brechas, de espessuras 
continetrioas a decimetricas, paralelas d forma do corpo gronitico.

Observendo-se a texture fluidel, descrvolvide on zo nas miloniticas, nota-se aue o desloconento foi sub-paralelo ds zonss de movimentanso. A defornecno foi repetida, como indicado pela presenge de falhas que cortam parajelemente os milonitos. Nos granitos Mairiporã e Contareira: trabém estão presentes falhementós e zonas de milonitos e brechas. Thm tôkas as pedreiras visitadas e em afloramentos rezóveis, principalmente ao Iongo de cortes de estradas, sz̃o observévejs efejtos de deformaçoses sofridas pelos grantitos.

Apresentem, principalmente para o Branito Contarej ra, as seguintes caracterfsticas:

1) Deformacões que resultaram em falhamentos foram repetidas, frequentemente seguindo antigas zonas de movimento.

Os falhementos mais antigos remontem tépoca sa quil os granitos se formaram. Fom verios afjoramentrig foran obsexvedos delgados aplitos ou vejos greníticos ao longo de planos de pequenas falinas reverses, onde as "crmadas gujasi são a-

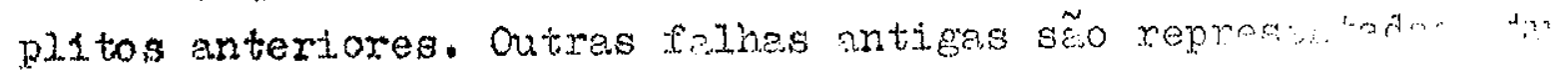
almente pox veios escuros, centimétricos a decinétxicos, ricos em tumalina e surrtzo, de granulação sub-milimétrice.

Falhrs, provivelmente, menos antigas sâo as zonas milonituces ou breches, de côr verde, onde eptato 6 o mineral dominante. Wste mineral deve se ter formado como consegrâncja da atividade de soluções hidrotermais, cue percrindo ao lonso de zonas novimentades, provocaram alteracöos, principalmente nos plagioclasios e biotitas.

Telhamentos max novos (ou contemporsneos) we os a cima descritos, levaram a formacão de rnilonitos e krechas, cujas espessuras, excepcionalmente, ultrapassam um metro.

Nos milonitoe as posicões dos porfiroclastos, frag mentos de rochas e elementos lineares, sugeren que o desiocanen to dos blocos se deu com omporente horinontal ou dixecional. ds atregbes dos falhamentos găo frequentemente paralelas à es- 
trutura regional, os marguhos nẽo säo unjormes no engulo nen no sontido, mas predominem angulos de merguno superiores a 709 e, muitos vêzes, ouasi verticais.

jithas mats modernas ỗo carecterizadas peln exian tência de brechas sem epidotzacẽo e planos de falhas abextos, não ninerelisedos ou apenes por sulfetos.

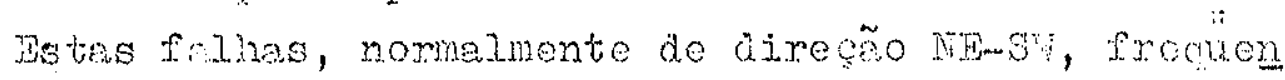
tomente acomanham milonitos ou brechas mais antiges. Nos planos

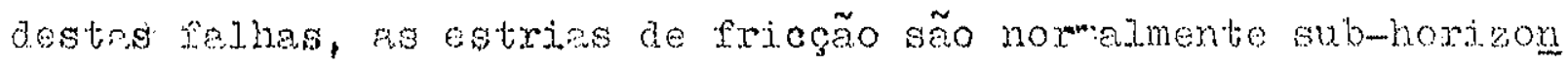
tnis o, näo raro, o mexgutho do plano de falha räo 6 uniforme, com variagõos no Ângulo de mergulho.

2) Nos falhamentos observados, quando presentes de mentos guie, os deslocmentos foram pooranos.

L existência de falhamentos reetivados, de direcão preforencial NBmb e rejeito com componente direcional, fot rem conbecida primeiramento por ilmeida (1955). Para este futor, a reatuvecão de antigas falhes, en cempos recontes, weria contribuido para a gênese da lnuta sedjnentar de sẽo Paulo.

Almeida (1955) após analisar os milonitos axistotites, principalmente, em pedreiras locelizadas nas proximidades do contato 5 do grenito Cantareira, deduziu a existsencia de 3 zonas principejs de falhemento. As dus primeirss, de dirocão NEm e rejeito aireojonal, forem por este futor denoninedes te

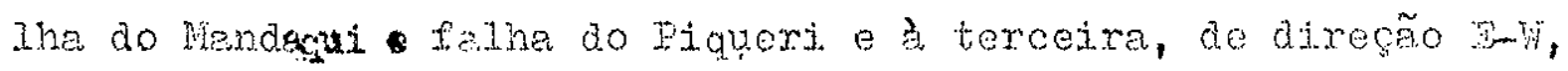
denominou-a palna de Iremembé. 


\section{VIII - IDHDE DOS GHANITOS}

Foram feites 10 determinações de idade pelo metodo do K/Ar (*) usando-se of seguintes minerais: biotita, muscovita, lepidolita e microclínio. Os resultados obtidos são apresentados na tabela abaixo.

TABELA III

Mineral

1. Biotita

2. Nicroclento

3. Toxidolita

4. Biotita

5. Biotita

6. Biotita

7. Muscovita

B. Nuscovita

9. Lepldolita

10. Lepldolita
Procedencia

Pegmatito, no grenjto Cantareira

idem, idem

Pregmatito, no turmalina granito, Perus

Granito Mairiporã

Granito Cantaxeira

Granito, Pedroira Anhanguera

idem, idem

iduem, idem

Pegrnatito, no turmalina grenito, Derus

idem, 1dem
Idade (milhooss de anos)

$$
\begin{aligned}
& 501,6 \\
& 490,7 \\
& 643,0 \\
& 517,5 \\
& 495,5 \\
& 589,7 \\
& 595,0 \\
& 576,6 \\
& 655,0 \\
& 770,3
\end{aligned}
$$

Para as antises de lepidolita, este mineral foi re tiredo de pegmatitos ricos em turmalina e lepidolite, que arjoram no contato norte do granito Cantareira, no runiclyio de rerus. As amostras de biotita e muscovita, das anclises 6,7 e 8 são do granto que afiora no morro do Tico-Tico, na via Jnhangrera. Aste grenito corta as rochas da serie são Rogue e apresenta, além da biotita, abundância em muscotita. Nesta rocha a biotita não apresonta cloritização, ao contrário da dos granitos ora estudedos. 
Ls idades obtidas, apresentadas na tabela IIT, mos tram um minimo de 490,7 mithões de anos e un méximo de $770,3 \mathrm{mi}$ Ihões de anos. Os valores menores referem-se ao microclinio o biotita do grenito C mareira.

Como je foi mencionado no capitulo referente a petronrafie dos grantitos, o microcltnio sempre contém inclusões e e biotite, en maior ou menor intensidade, mostra indícios de cloritizenão. Estas alteraçóes devem ser, pelo menos em parte, responsáveis pelos bajxos valores obtidos.

Li idade das lepidolitas, on pegmatitos certanente contemporâneos ou mais novos que o granito encaixante, revelou idade mais antiga. Ista discrepancia nas. nnalises de lepidolita, provàvelmente, se devo à presenca do lítio (

Se as idades obtidas com muscovita o biotita não alteradas forem confirmadas, os granitos sintectônicos e a oro Gênese da série São Roque ficarão definitivamente enquadrados no Pré-Cambriano Superior.

(*) - As andises de ns, I a 3 foram realizadas na universidade da California, Berkeley, por J. G. Cordenj. As anélises de ns, 4 a 10 foram feitas no Laboratbrio de Geocronologia, da Üniversidade de Sto Paulo, sob orientaça do Prof. Dr. John-Reynolds pelos Instrutores G. kamaral, U. G. Cordani e K. Kawashita, aos quajs o autor agradece a colabo. raço prostada.

(**) - Informaçõo verbal de U, G, Cordant 


\section{$I X-$ CONCLUSOES}

1. As rochas metassedinentares que predominam na regièo estux dada são xistos e filitos, formados a partil de sedimen tos originalmente pelfticos e psamiticos. Fitruturas primáxias, como estratificação e acamamento gradativo, são frequentenente observáveis.

2. Os metassedimentos possuem orientaço regionaI NE-SW, com calmento do Iineamento para NE. Nas proximidades dos corpos grańticos, ao dobramento regional, foi superimposto dobramento secundário, como resultado àa acomodaça, por ocasião da colocaģ̃o dos granitos.

3. Os Bxanitos, formando três corpos principais - grantito Cantareira, Mairiporă e granito-gnáisse - acham-se orientados paralelamente à estrutura regional. Os contatos são intirusivos e geralmente bmuscos.

4. Os granitos Cantareira e Mairiporã gão ricos em encraves de rochas anteriores. No primeiro predominam inclusöes de xistos e anfibolitos, em escala mesoscópica e megascópica. No segundo, apenas em escala mesoscópica.

5. A orientação dos encraves, principalmente no eranito canm tareira, E paralela à orientação das encaixantes. Aste pa raloligmo diz respeito também à direçẽo e sentido do cajmento do Ineamento.

6. Caracterfatica comum nos granitos es a presonon de porftro. blaston de microclínio. São centintericos excepcionalmen. te o comprimento pode exceder $10 \mathrm{~cm}$.

7. Os plagioclásios pertencem a duas geraçoes. Nos da primoi ra ceração normalmente estão presentes sericita e eplato. os da segunda gexaça geralmente são frescos e podem conm ter inclusōes de plastoclásios da primeira geração. 
8. Nos granjtos o mineral máfico dominante é a biotita pela disposição imprime a foliacróo da rocha

9. A biotita quase sempre mostra indicios de que foi afetada por atjvidade hiarotermal, que provocou cloritização prrcial ou total. O infcio da alteração hidrotermal e a libertação de $\mathrm{TiO}_{2}$, oom formação de leucoxênio e posteri ormente titanita e a mudança para côr verde. Epidoto tam bém ae desenvolve a partir da biotita, durante o processo da cloritização.

10. O microclinjo é de origem metassonática e desenvolveume com contribujęão parcial de plagioclástos da primeira ge ração. Oo remanescentes de plagioclásjos sericitimann. dentro de microclinios, normalmente mostram uma zona exw terna limpida e mais rica na molécula ae albita.

11. No quartzo quase sempre se notam sinais de aiforcos Anre sertan extinção ondulante, frequentemente finamente granulados, 引̀s vêzes, formendo rosários, entre feldspatos menos afetados.

12. Nos eranitos, como consequência da etividade hidrotermal, foxmaram-se epidoto, serictta, titanita e tambem, provàvelmerte, apatita.

13. Nos granjtos são heterogêneos os volumes de quartzo, feldspatos blotita. pelas relaços dos volumes entre plagloclásio e microclínio estão representados desde quartzo-dioritos at ' granitos verdadeiros. No entanto, predominam granodioritos.

zonas de contato hat evidências de enriquecinjento de quatzo por contaminą̧ão das encaixantos.

24. Admiteme que os granitos sejam sintectonicos, nos quais grande parte do magma formou-se "in situ", pela fusão rar cial dos metassedimentos. 
15. Apbs formąăo da rocha intrusivg, atividade hidroternal, au xiliada por esforços tectonicos gue cisalharam a rocha, pro vocou altexaçóes principalmente nas biotitas e plagioclási-os. A fase hidrotermal foi acompanhada de processos netasso máticos, que levaram ao desentolvimento da segunda geracão de plagioclásios e do mioroclúnio.

16. Os pegmatitos, principalmente pegmatitos turmeliniferos e turmalina grantos, desenvolverem-se durante o processo, metassomático e representam o final da atividade do magma.

17. Rochas metassedinentares clésticas e quimicas passaram a hornfels, em zonas de contatio ou en inclusões nos grani-.. tos.

1.8. A granitização dos xistos, em pequenes f́reas, resultou cm associações mineralogicas semelhantes ह̀s dos granitos. Plam gioclásios e mieroclínio, além da biotita, mostran jânticas relações paragenéticas às observacas nos granitos.

19. Falhamento e cisalnamento nos granitos foi repetido. os $\mathrm{mi}$ lonitos e brechas, na sua maioria, orientam-se peralelamen te a estrutura reglonal. Rejeito, com componente direcionad, comum.

20. Determinaçöes de idade, pelo metodo do $\mathrm{K} / \mathrm{Ar}$, indicam para os granitos lade pré-cambriana superior. 
Almeida, I. F. M. de, 1953, Consjderações sôbre a geomorfogêe nese da serra do Cubatão: Bol. Paul. Geoor. (Assco. Geogr. Brasil.), n. 15, p. 3-17.

Almeida, F. F. M. de, 1955, As camadas de são Paulo e a tectônica da serra da Cantareja: Bol. Soc. Bras. Ge$01 ., v \cdot 4, n \cdot 2, p \cdot 23-40$.

Andreata, $0 ., 1954$, Ubex die Verglimmerung dex Plagioklasots. der tektonischen Metamorphose: Tşherm. Min. Petrog. litt., B. IV, n. 1-4, p. 350-359.

Bajk, R., 1948, Stmucutural behaviour of igneous rocks: repr. Geol. Soc. Amer., Memoir 5, 117 p., Edwards Brothers Inc., Michigan, USA.

Barbosa, 0., 1941, Geologia e Petrologia na região de Apiai., Estado de São Paulo: Tese para concurso da Cadeira de Geologia, Petrografia e Minoralogia, Wsolc Politécnica da Universidade de são Paulo.

Barsukov, V. I., 1961, Some problems of the Geochenistry of Boron: Geochemistry, trad. de Geokhimiya, n. 7, p. 596-608.

Beloussov, V. V., 1962, Basic problems in geotectonics: MeGraw-Hill Book Co., Inc., N. York, 809 p.

Bergstrom, I., 1963, Petrology of the Tjom Area in rifstern Sweden: Sver. Geol. Undors: Ser. O., 11. 593, 134 p. Chayes F., 1952, Association of perthitic microcitine with. highly undulant or granulat quarta: Am. J.Sc., V. $250, \mathrm{n} .4, \mathrm{p} .281-296$.

Chayes, F., 1955, Potash-reldspax as a by product of the bio tite-chlorite transformation: J. Gool., v. 63, n. 1. p. 75,82 .

Chayes, F., 3957, A provisional reclassification of granite: Geo1. Nas., v. 94, n. I, p. 58-68.

Chong, Y. C., 1943, The migmatite area around Bettyhill, Sutherland: Quat, Jour. Geol. Soc. Iondon, v. 99, part. 3 e 4, p.107-148.

Cloos, E., 1948, Lineation - A critical review end annotated. 
biblisgraphy: Geol. Soc. Amer. Wemojr 18, I22 p. Cordani, U. G., Campos, A. R., Davino, A. e Bjorrberg, A. J. S., 1961, Geologia da rofião do Jaragrá, S. P.:Bol. Soc. Jxas. Gool., v. 10, n. 2, p. 72-.9J.

Gordani, U. G., Gomes, O. de e Girardi, V. A. V., 1963, Row chas cólciomsilicatadas da remiño ae Eorus, B. P. : An. Acad. Bxas. Ciên., v. 35, n. 3, p. 36L-372.

Coutinho, I. M. V., 1953, Potrolonta da rogino do säo Bomo, S. P.: Pac. Til. Cion. Lotr., U.S.P., Bol. 159, Min. $11,80 \mathrm{p}$.

Coutinho, J. N. V., 1955, Tiotroonglomexado o roches associadss

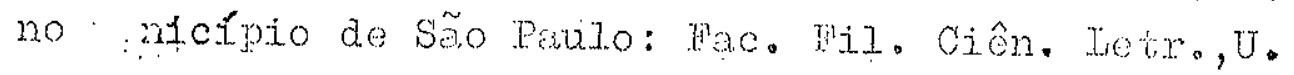
S. P., Bol., 1.86, Mir. 13, p. 5-55.

Doer, W. A., Howje, R.A. e Zussman, J., 1962, Rovk forming mi nerals: Longmans, Green and Oo. Ita., Londros, $4 \mathrm{~V}$. De sitter, I. U., 1956, Structural Goology: Hedraw-ili Book Co., Inc., N. York, 552 p.

Wlicet, R., 1961, Contribuifro è ceologia do pré-chmbriano nn região de são Bomardo do Campo, S.E. Bol. Soc. Bras. Gool., v. 6, n. l, p. 49-56.

Eskola, P., 3956, Postmagmatic potashmetasomatism of frante: Bull. Comm. Gool. Finzande, n. 1.72, p. 85-100.

Franco, R. R., 1958, Contribuigeno ao conkecimento ass rochas tormomotamórficas da série são Rongue: Fro. Fi. Cich. Letr., U.s. P., Bol. 189, Min. 14, 81. p.

Gomes, C. de, 1962, Contribuição ao conhocinentio dos anfiboli tos da região do Jaragua, S. E.: Bol. Soo. Bras. Geol., v. I. , n. I, p. 57-78.

Guimerãos, D., 1936, o procosso da microclinizaç̃o: An. Acad. Bras. Ciŝn. v. 8, r. 3, p. 205-215.

Gujnarães, D., 1.937, Contribuicão d notalosonose do passico. Bresiloiro: Dop. Nac. Prod. Jin., Borv. Fom. Prod. Min., Bol. $16,86 \mathrm{p}$.

Hell, A., 194], the relation betwoen color and chemical compo sition of biotite: Am. Nin., v. 26, n. I, p. 29-34.

Fiary, W. 2., 1953, Jhe composite granitic gneiss of nestern. Ardegur frgyld: Ouat. Joux. Geol. Doc. London, vol. 104, n. 455 , parte 3, p. $285-308$. 
Hasui, Y., 1963, Sôbre Granitos turmaliniferos de Perus, S.P. :Bol. Soc. Bra.s. Geol., v. 12, n. 1 e 2, p. $87-108$.

Knill, D. C. e Knjli, J. I., 1961, Time relations between fol. ding, metanorohism and the emplacement of Granite. in Rosgla11, County Donegal: guat. Journ. Geol. Boc. London, v. 117, n. 467, parte 3, p. 273-302.

Knopf, A., 1957, 1'o Boulder Bathylith of Nontana: Hu. J. Sc. v. $255, n \cdot 2, p \cdot 81-1.03$.

Teonardos, O. H., 1934, Chumbo e prata no Brasil: Dep. Nac. Proa. Min., Ber. Fom. Prod. Min., v. 2, 116 p.

Iisitskyn, A. E. e Khitrov, V. G., 1962, A mjerospectrochemical. study of the distribution of boron in minerals of so me igneous and metamorphic rocks of the pijale Urals: Geochemistry, trad. Geokhimya, n. $3, p .293-$ 305 .

Marmo, V., 1956, On the emplacement of granites: Am. J. Sci., v. 254, n. 8, p. 479-492.

Marmo, V., 1962, On granites: Bull. Comm. Geol. Finlande, n. 201, $77 \mathrm{p}$.

Marmo, V., 1961, On the albite of granitic rocks: Bull. Comm. Geol. Finlande, n. 196, p. 391-398.

Moraes Rêgo, I. F. e Souza Santos, T. D. de, 1938, Contribui... ção para o estudo dos granitos da serra a Cantarej ra: Inst. Pesq. Tec. S. Paulo, bol. $18,162 \mathrm{p}$.

Nickel, 2., 1953, Zur Pexthitbildung aurch Plagioklastesorption bei Kalifelaspate: N. J. f. Mis., Monatsheft, p. $246-264$.

Oliveira, A. I. de e Leonardos, O. H., 1943, Geologia do Brasil: Ministério da Agricultura, Serv. Informação Asrícola, série didátice n. 2, $813 \mathrm{p}$. , Rio de Janeiro Poldevart, A., 1953, Petrological calculations in metasomatic processes: Am. J. Sc., v. 25l, n. 7, p. 48.-504. Raguin. F., 1946, Geologie du granite: Masson, Cie., Ea., Pe ris, $21 . \mathrm{p}$.

Rankama, K. e Sahama, Th. G., 1950, Geochemistry: The Chicago Univ. Press, $911 \mathrm{p}$.

Read, H. H., 1957, Whe granite controversy: Thomas Wurby \& 
Con, Tondion, $430 \mathrm{p}$

Reynolds, D. In, 1943. The south-westem and the rown inge.w. ous complex - A contribution towards the petrogene sicy of the granodjorites: Mat. Jour. Geol. Soc. Iondon, $v \cdot 99$, partes 3 e 4, p. 205-240.

Rickard, if. J., 1961, b note on cleavages in crenulated rochi : Geol. Mag., v. 98, n. 4, o. 324-332.

Robertson, li. 1959, Perthite formed by reormanization of al, bite from plapioclase during potash feldspax meta... somatism: 4n. Min. v. 44, n. 5/6, p. 603..619.

Schwarts, G. M., 1958, Alteration of biotite under mesothor mal conditions: Be, Geol., v. 53, n. 2, p. 164-1777.

Semenento, N. P. 1960, wheory of metamorphim of mobile sow nes: Xx. Interm. Geol. Congr. (Nordern 1960), part $\mathrm{XIV}$, p. 62-71.

Swencer, N., 1937, The potash-feldspar stability: Min. Mrg., v. $24, p \cdot 453$

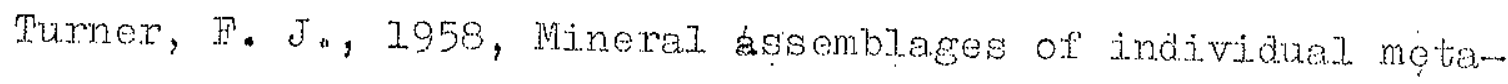
morphic, facies: Geol. Soc Amer*, Hemolr 73, p. $199-237$.

Turner, T. J. e Verhoogen, J., 1960, Tgneous and metemomphic petrology: MoGraw-Hill Book CDn, Tnc., No York, $545 \mathrm{p}$

Winlsler, H. G. F, e vor Platen, H., 2958, Frperimentelle Gew stejnsmetamorphose - II. Bildung von Anatektischen granjtischen S̈chnelzen bei Hetamorphose ron $\mathrm{NaCl}$ fuhrenden Kalkereien Tonon: Geoo. Cosm. Lota, v.15, n. 1/2, p. 91-1.11.

Winkler, H. G. T.e von Elaten, H. 1960, Experimentelle Gem steinsmetamorphose -.. ITI. Aratehtische U] irameta... inorphose Kalkhaltiser gone: Geoc. Cosm. Hota, $v$. $18, \mathrm{n} \cdot 3 / 4, \mathrm{p}, 294-316$.

Winklox, H. G. F. e von Plater, H, 1961, Experimentelle Ge stejngmetamorphose - IV. Bilduns Anatoktischer Schmelan aus metanorphisierten Graweken: Geoco Cosm. Leta, v. 24, n. 1/2, p+48-62。 


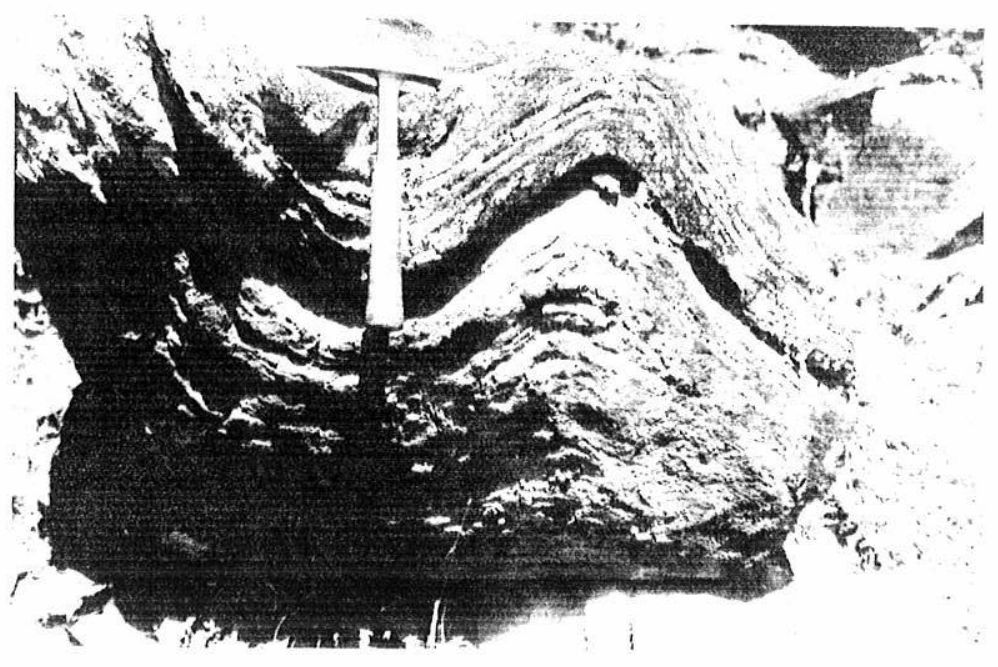

Foto no 1 - Dobra de arrasto, irregular, no xisto. Proximidades do contato SL do sranito Cantareira.

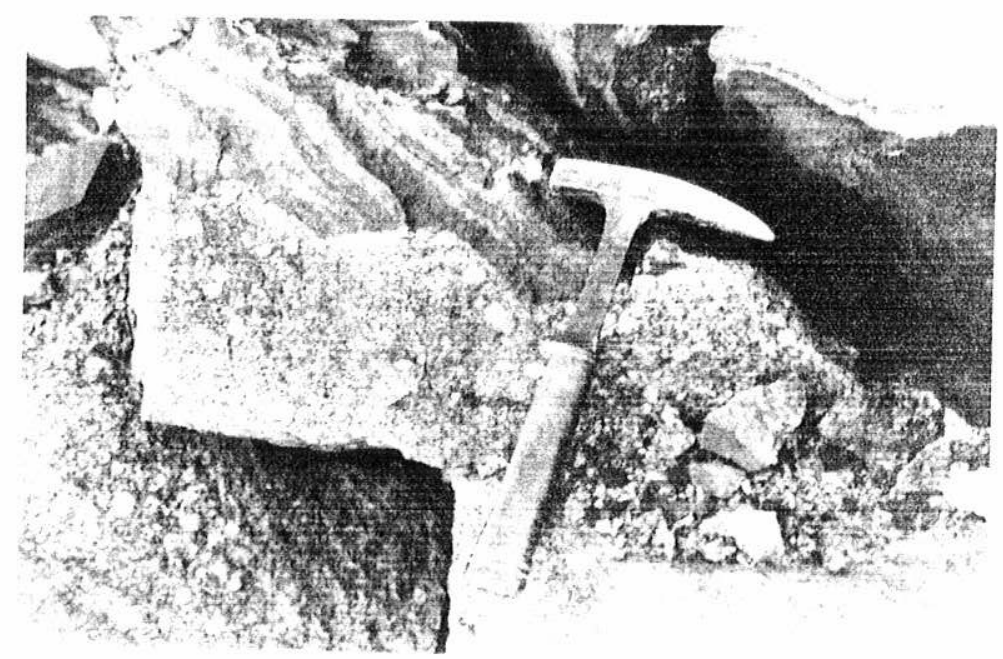

$\begin{aligned} \text { Foto no } 2 \text { - } & \text { Xenólito no granito, com estrutura } \\ & \text { palimpséstica. Granito Mairiponã. }\end{aligned}$ 


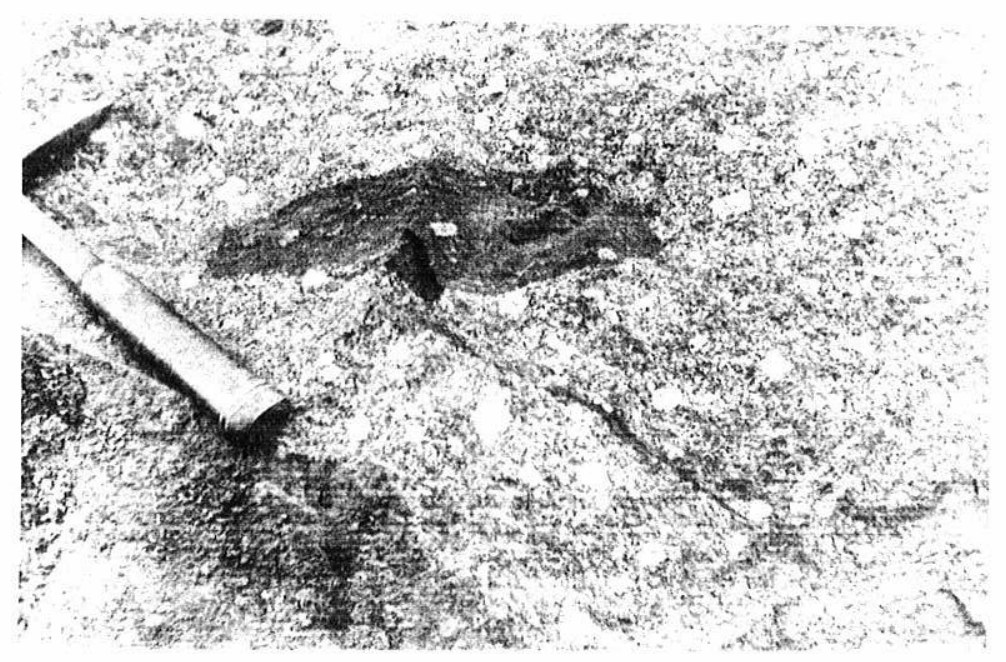

Foto. n. 3 - Xenólito no granito Mairiporã, com porfiroblastos de microclínio.

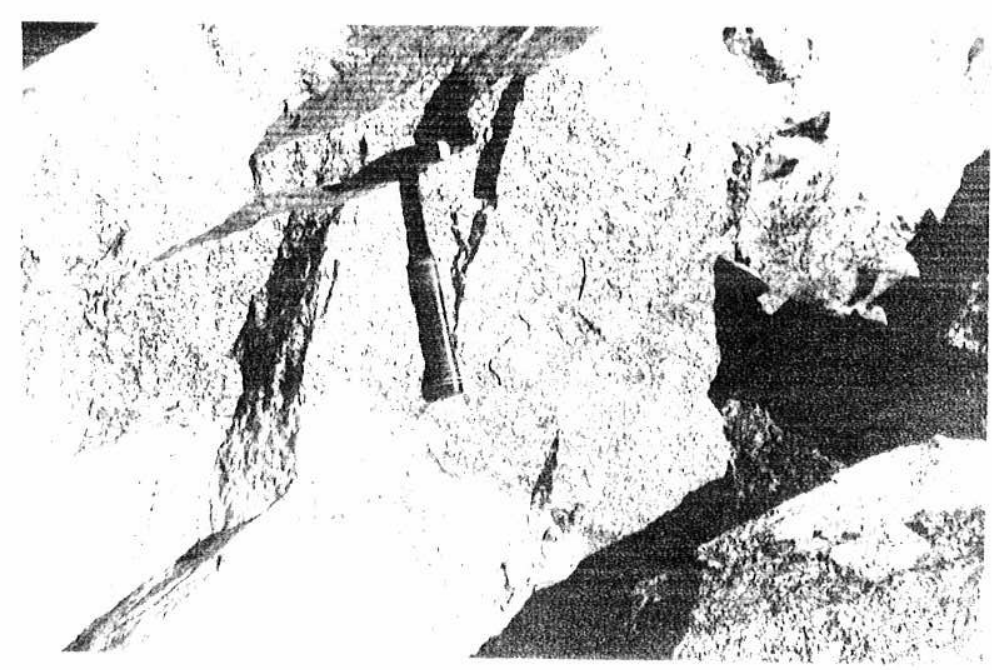

Foto. n. 4 - Pegmat1to formado por substituição do granito. No pegmatito as placs de bloti ta estão isorientadas com a foliação do granito. Granito cantareira. 


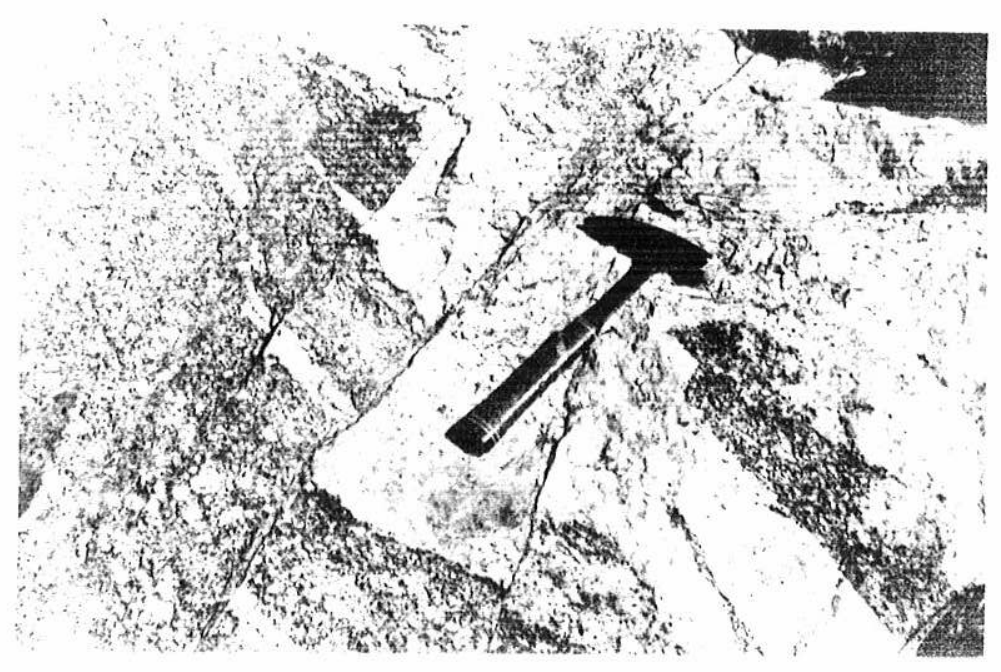

Foto. n. 5 - Pegmatito Pormado por substituição do gran1to. Lstão conservacios remanesm centes de granito não substituda. Granfto contareira.

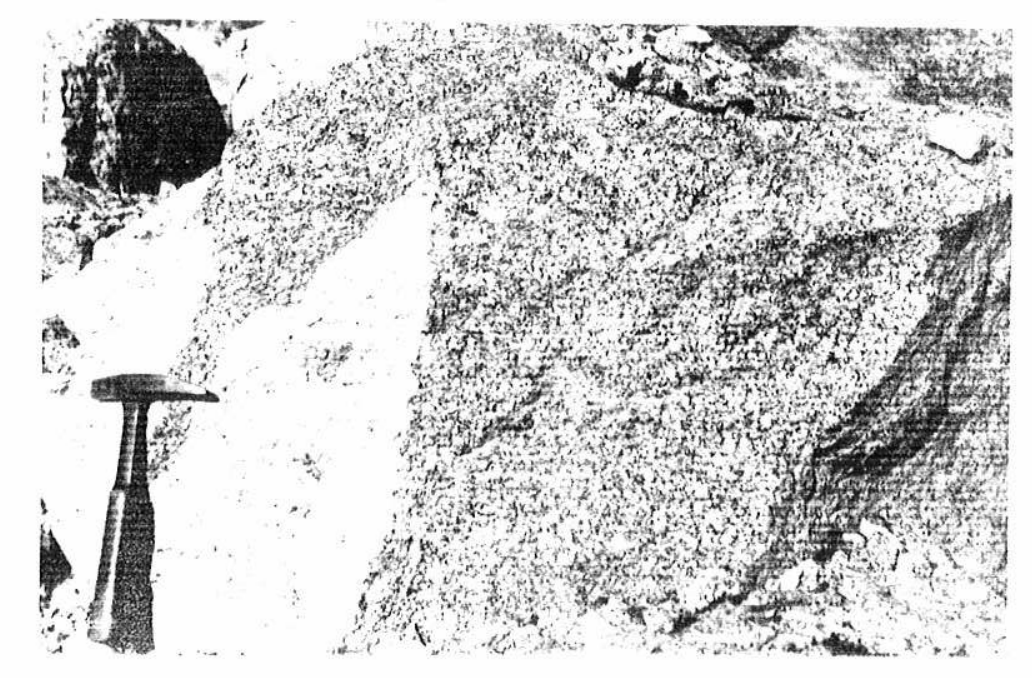

Foto. n. 6 - Zona pegmatólde irregular, no granito Cantaredra. 


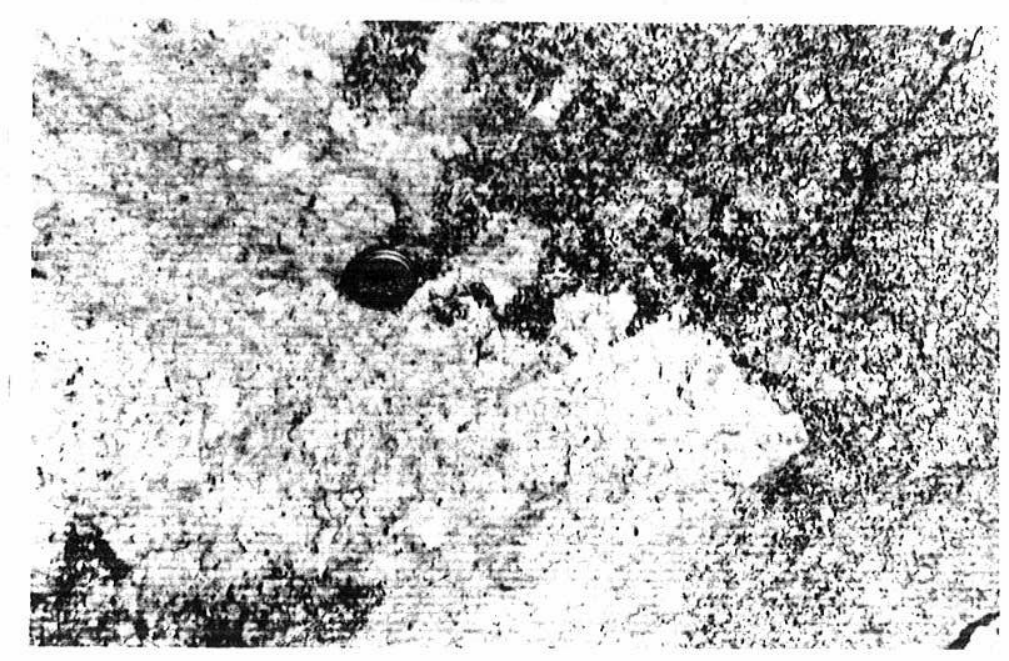

Foto. n. 7 - Zona pegmatóldo, com contato le transiçễo para graisito. Granto Cuntrarelra.

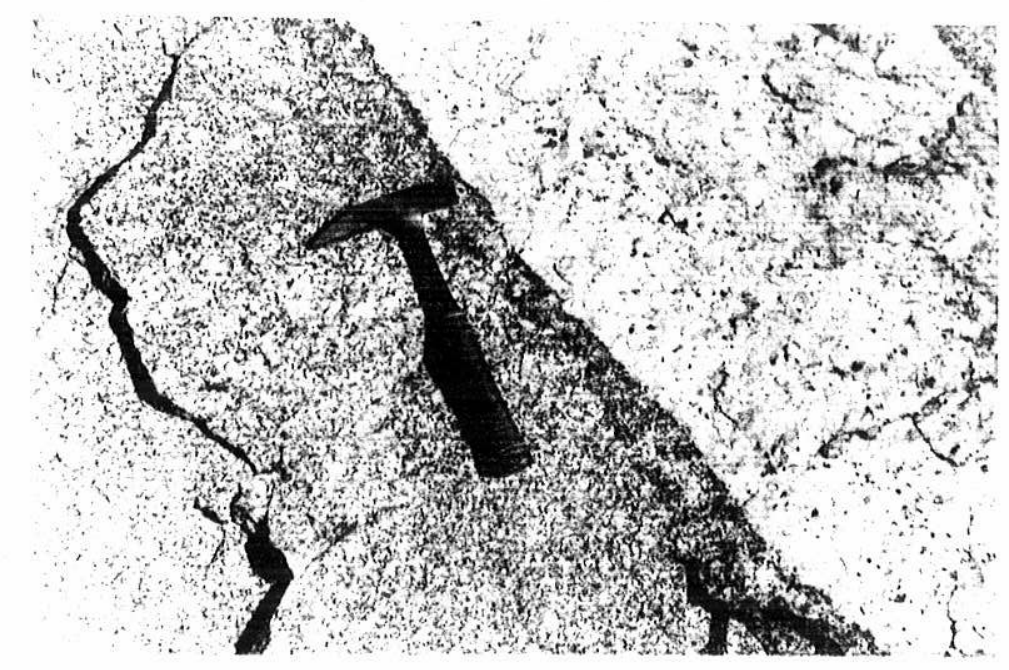

Foto. n. 8 - Dompatsto gon bunto granito. garant to cantarelra. 


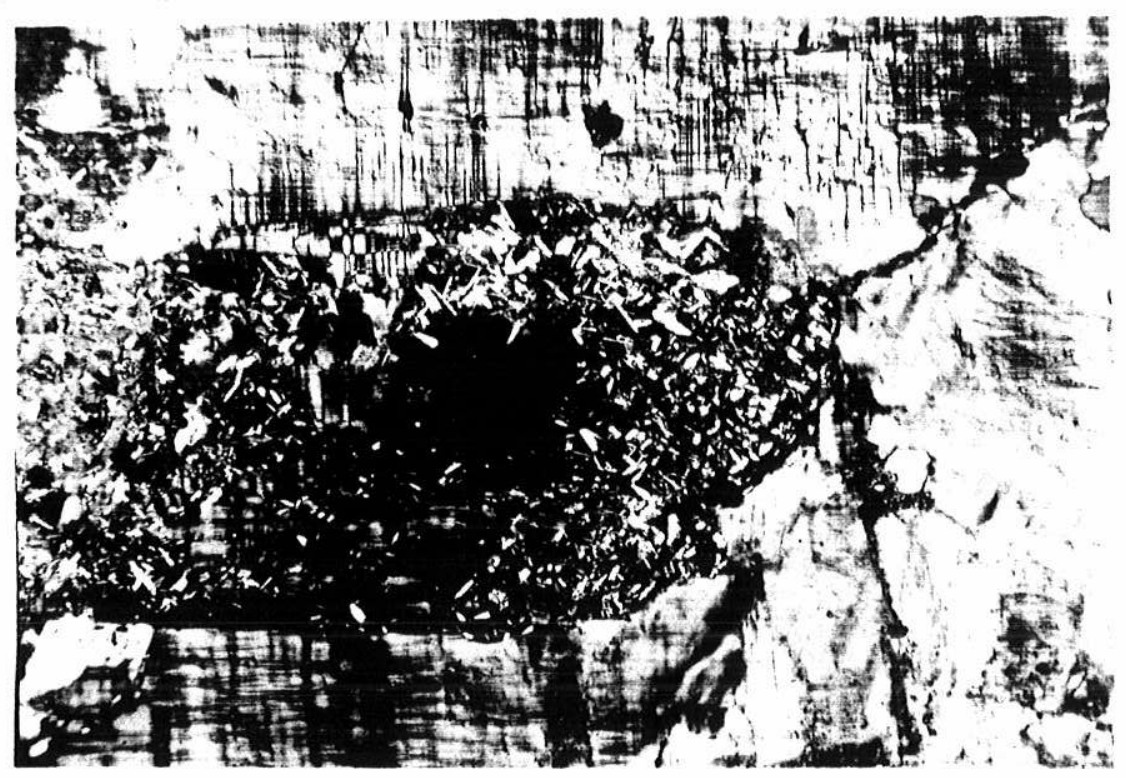

fotomierografio n. 1. MLacelinio substitulndo plaglo clúslo serle1t1zado. Grantio. NLeols x. Aumento 60 vêzes.

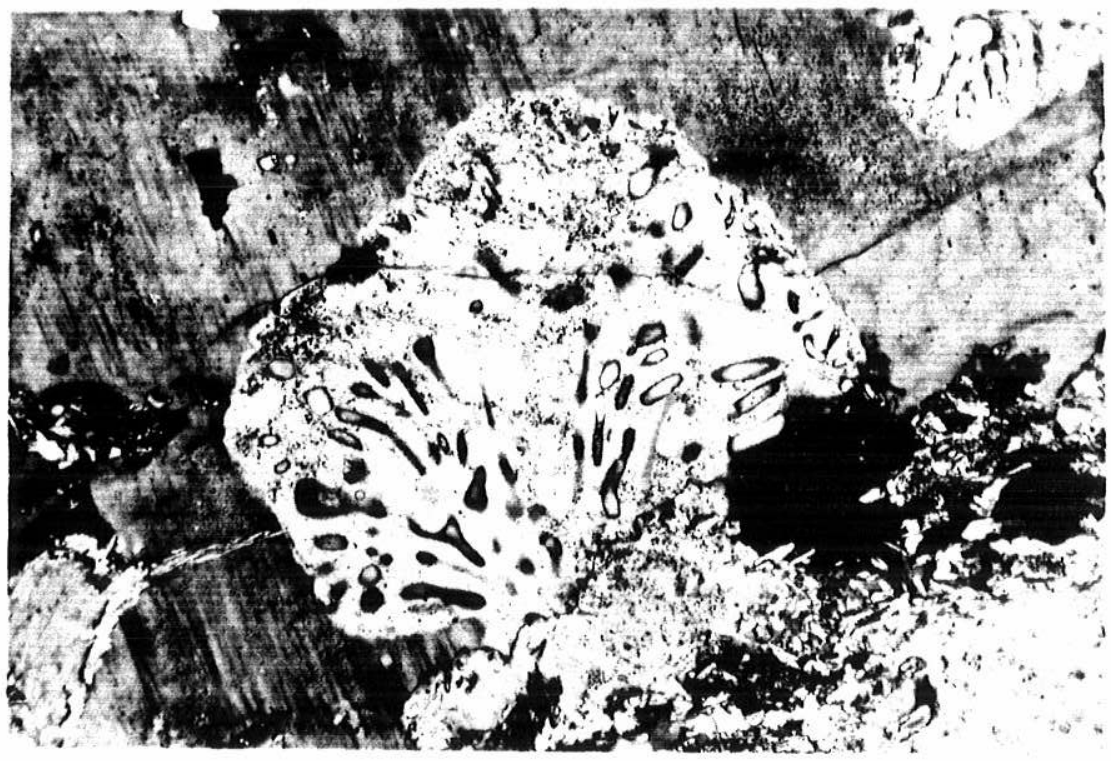

Fotomicrografla $n \cdot 2$ - Plagloclásio m1xmequltico englo bado por nicrocilnio. Grianito. Nicols $x$. Aumento 70 vêzes. 


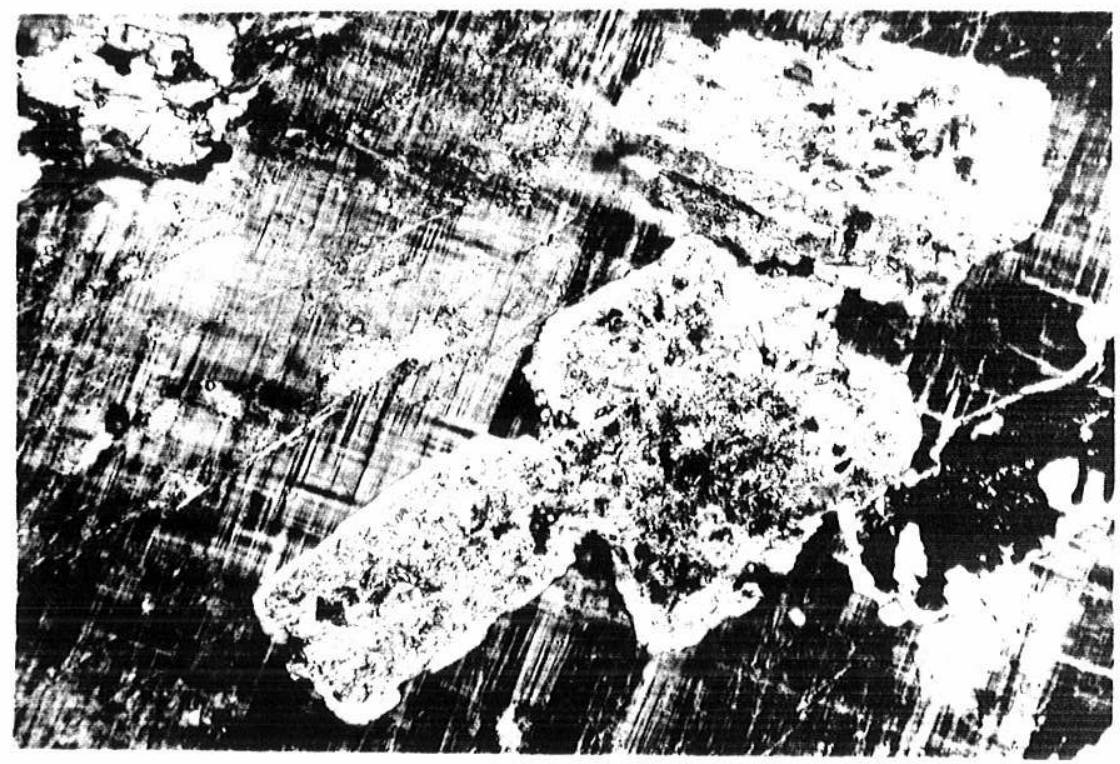

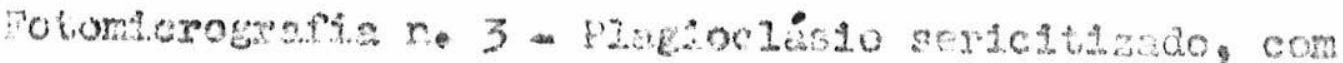 atyécla If.mptda, onglobacio en porsisro blasto de microclfnto. Granito. N . cols x. Aumento 70 vêzes.}

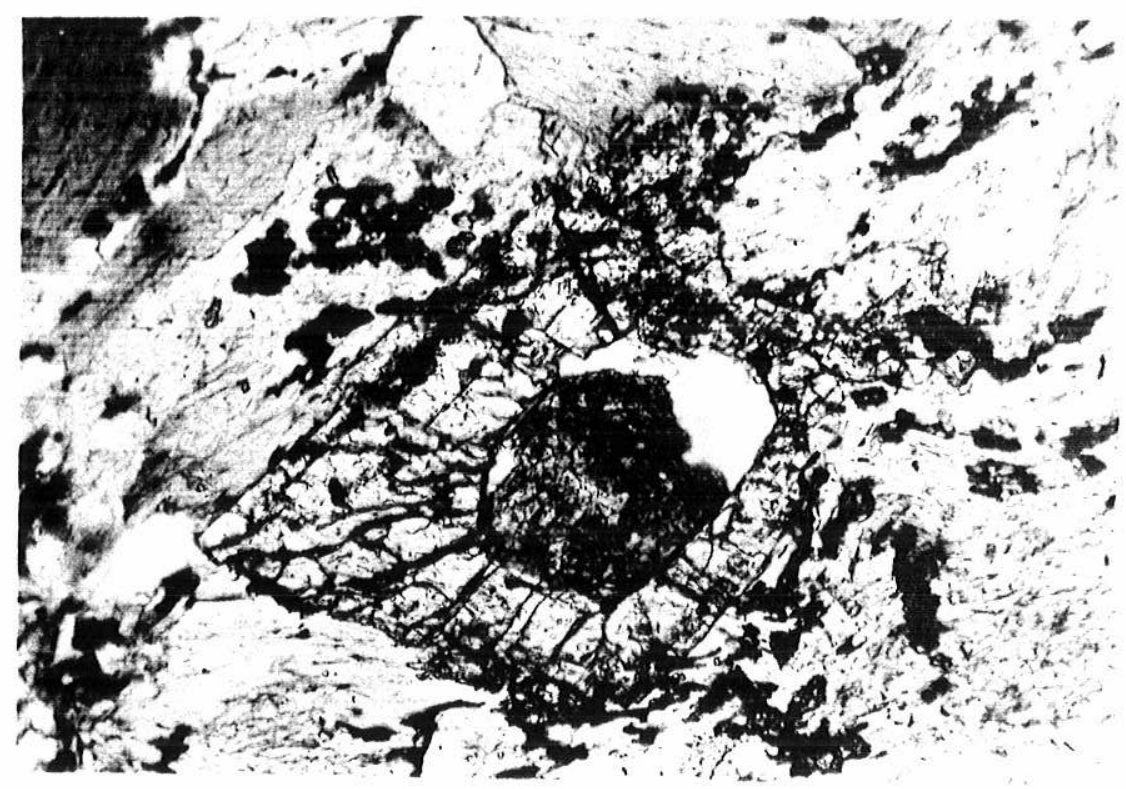

Fotomicrografla n. 4 - Allanita, alterada, envolvida por epldoto. Grantto. fools parale tos. Aumento 200 vêzes. 


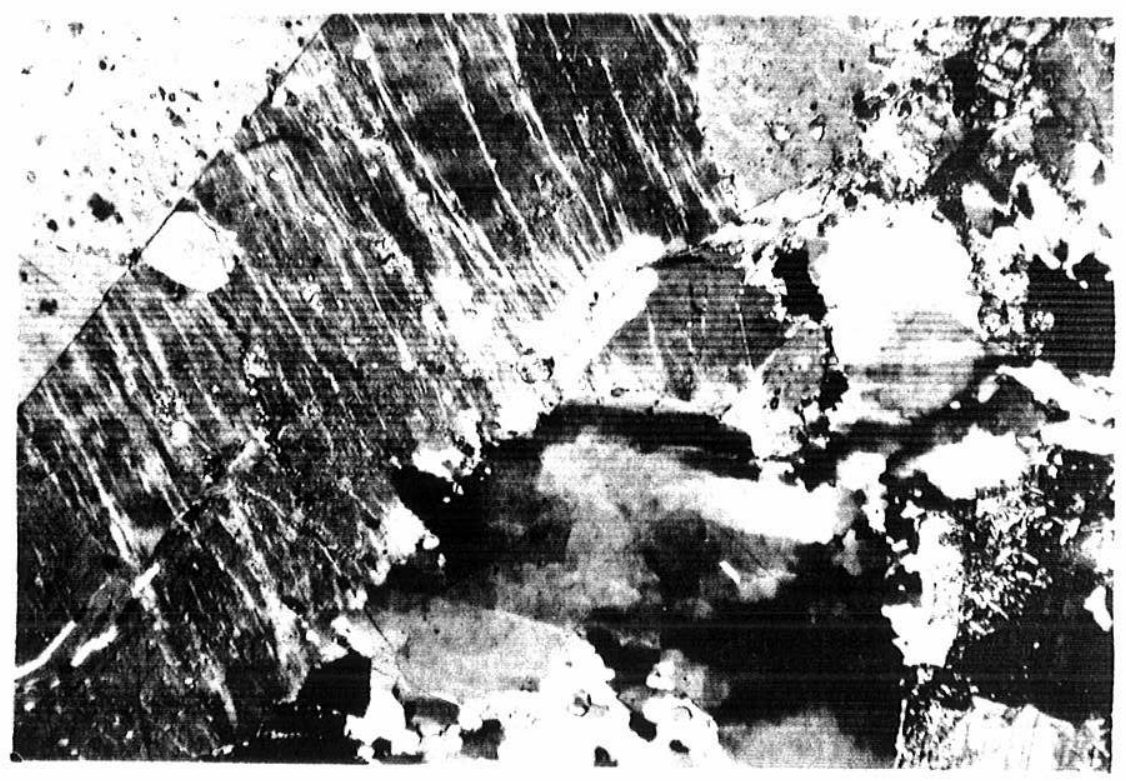

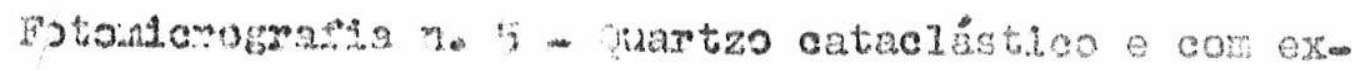
4n-

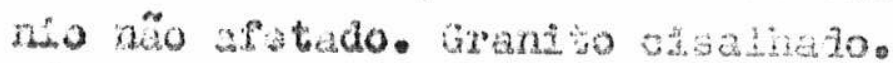
ateoss X. Aumento 25 vêzes.

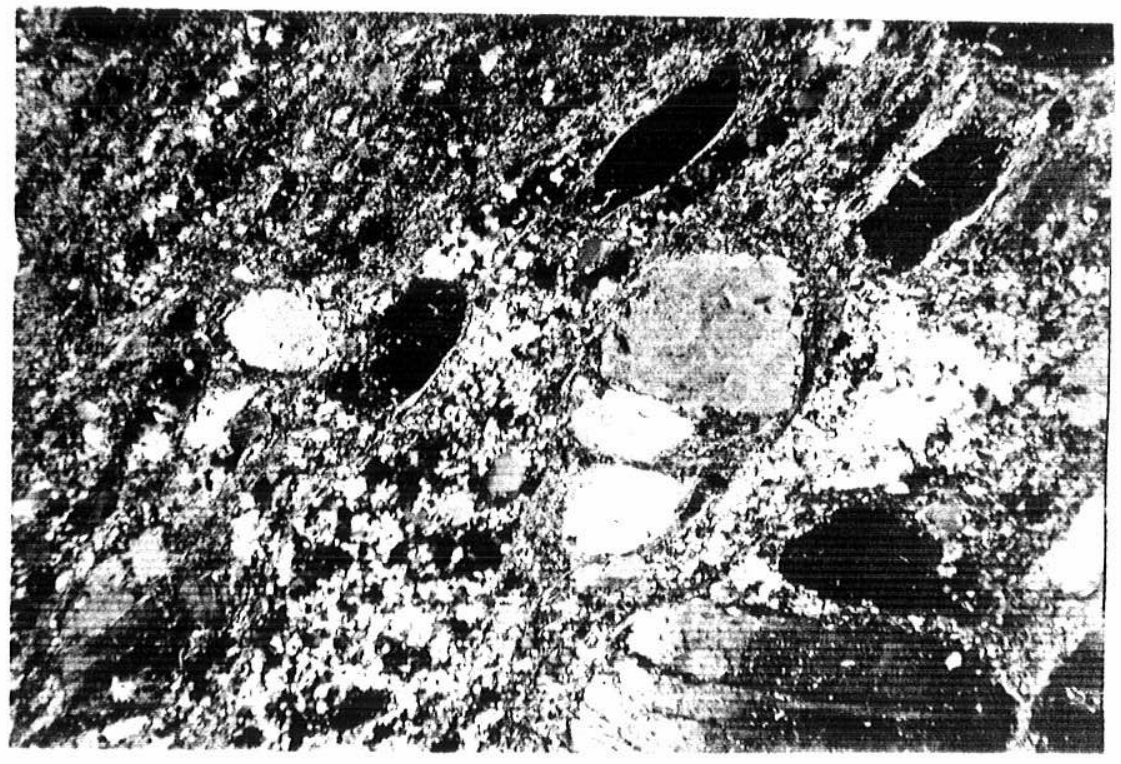

Fotomicrografia rim 6 - Zona mijonitica no crentow

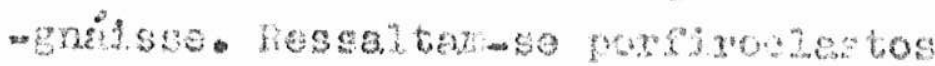
de fejaspatos. Mf́cols $\mathrm{K}$. Aunerto 25 vêzes. 


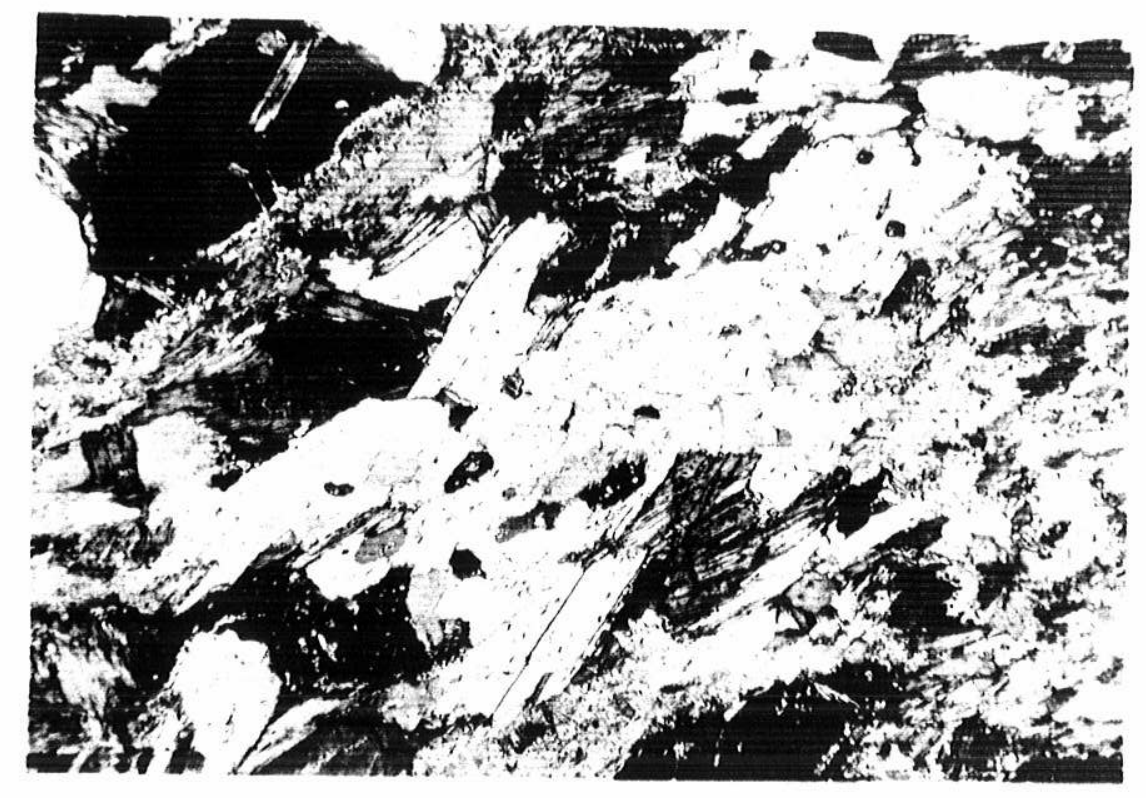

Fotomicrografia n. 7 - Biotita xisto, com porfiroblastos de rusovita, crescendo distonolnonto à

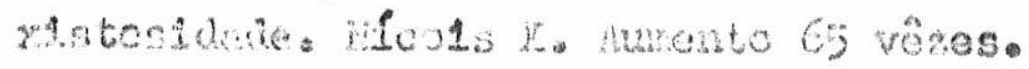

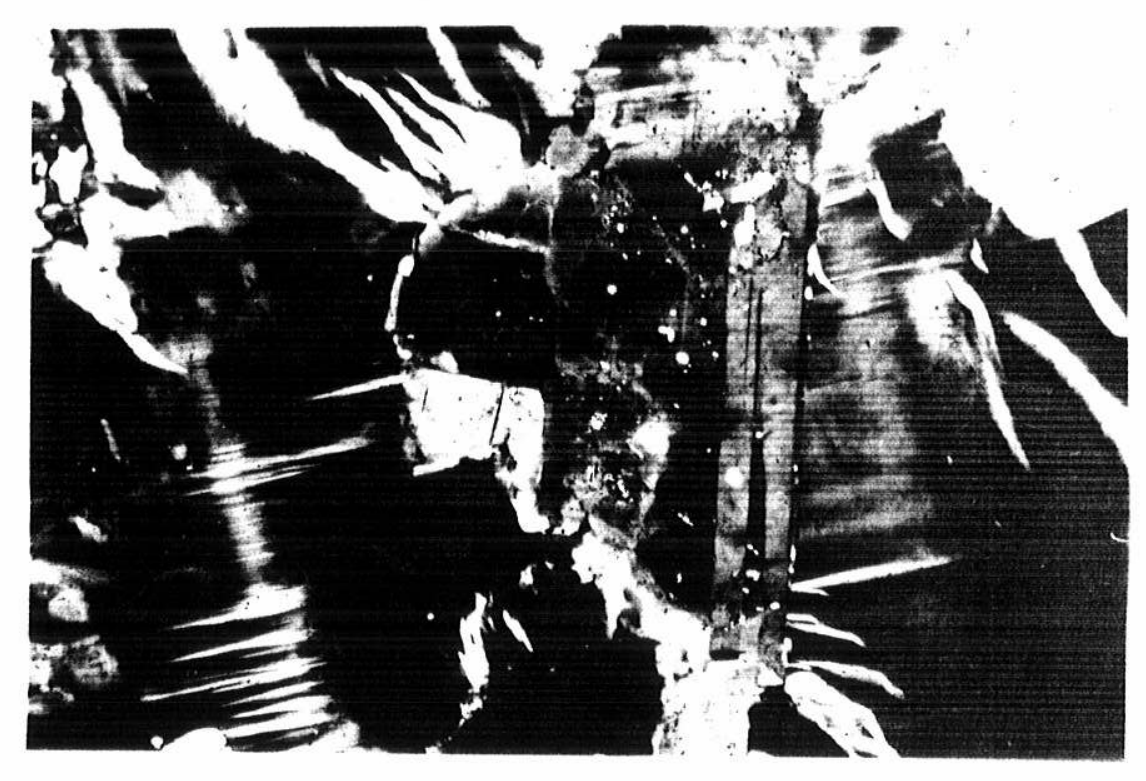

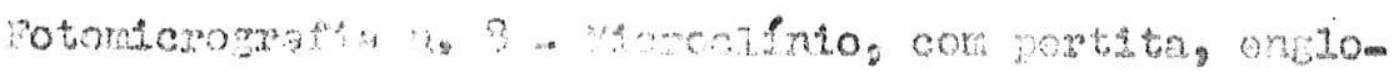

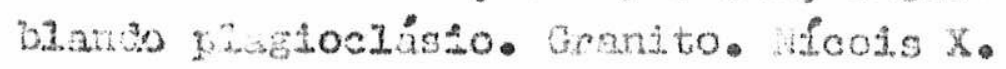
Aumentน 160 vêzes. 


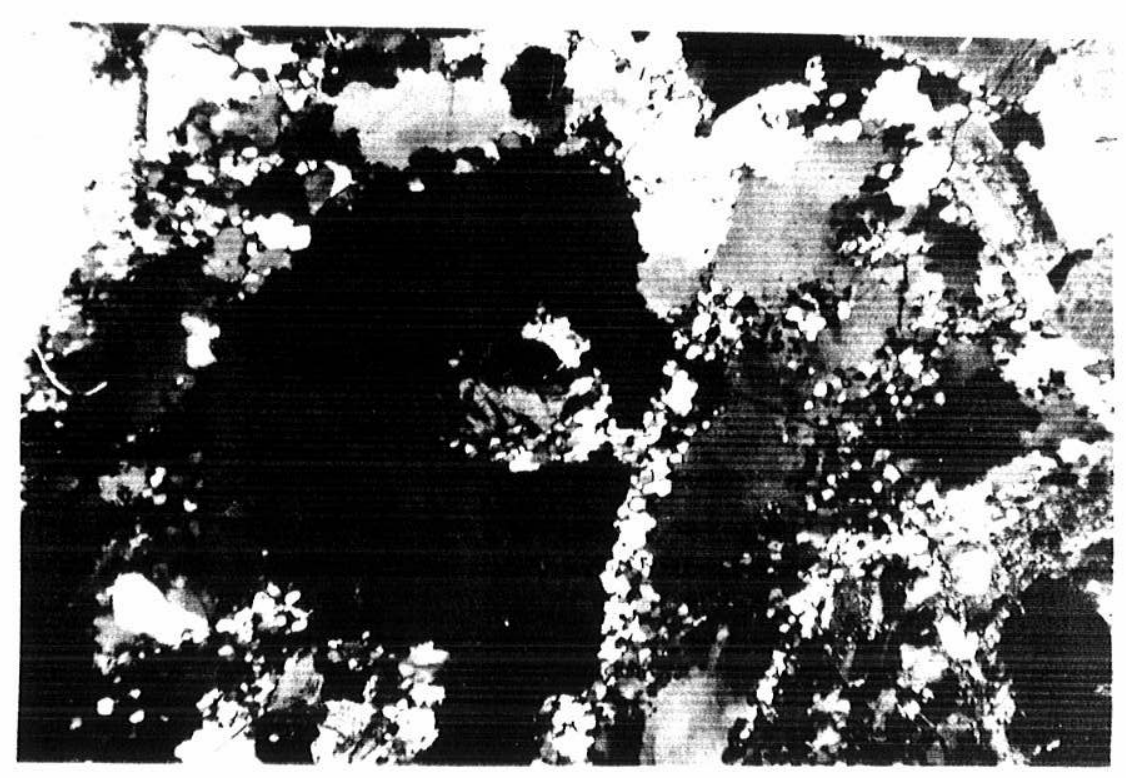

Potomicrografia n. 9 - exant to contaminado com quaztro.

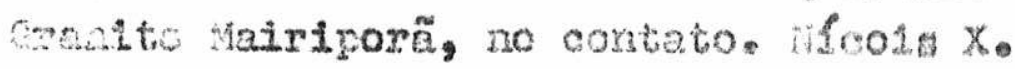

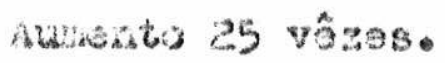

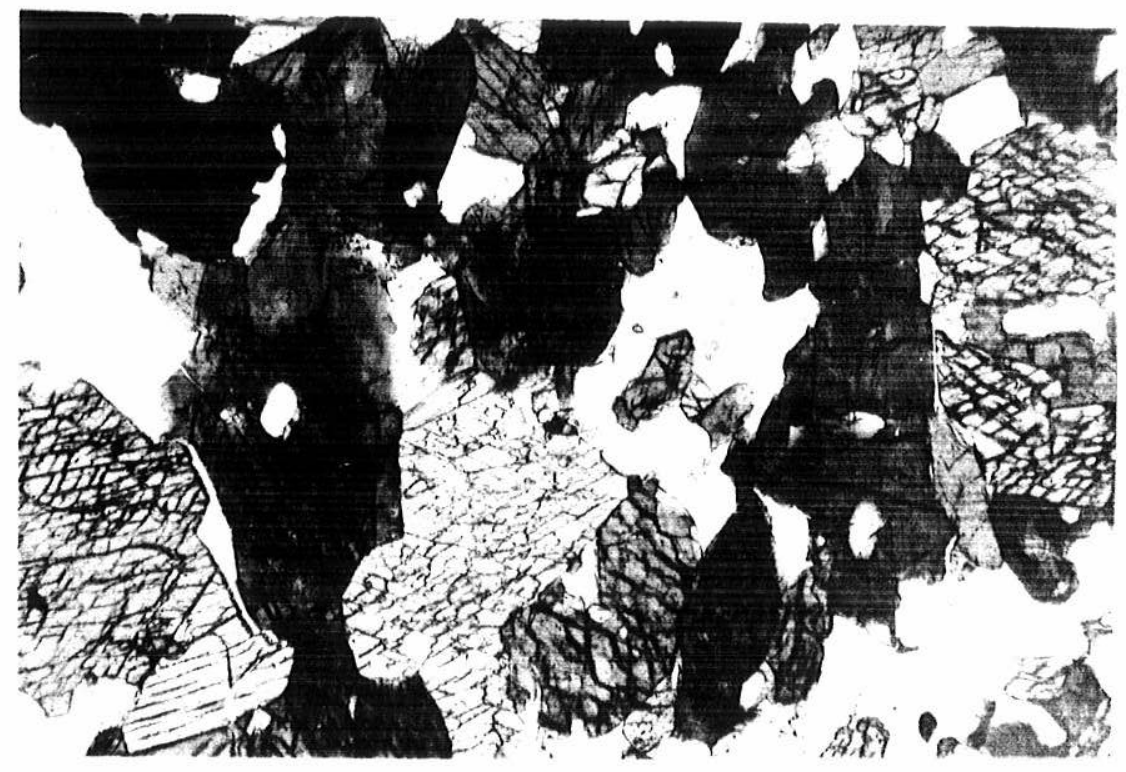

Fotomlcrogratia n. 4 - Anitibolito, no granito. ficho neraleios Aumento 65 vêzes. 


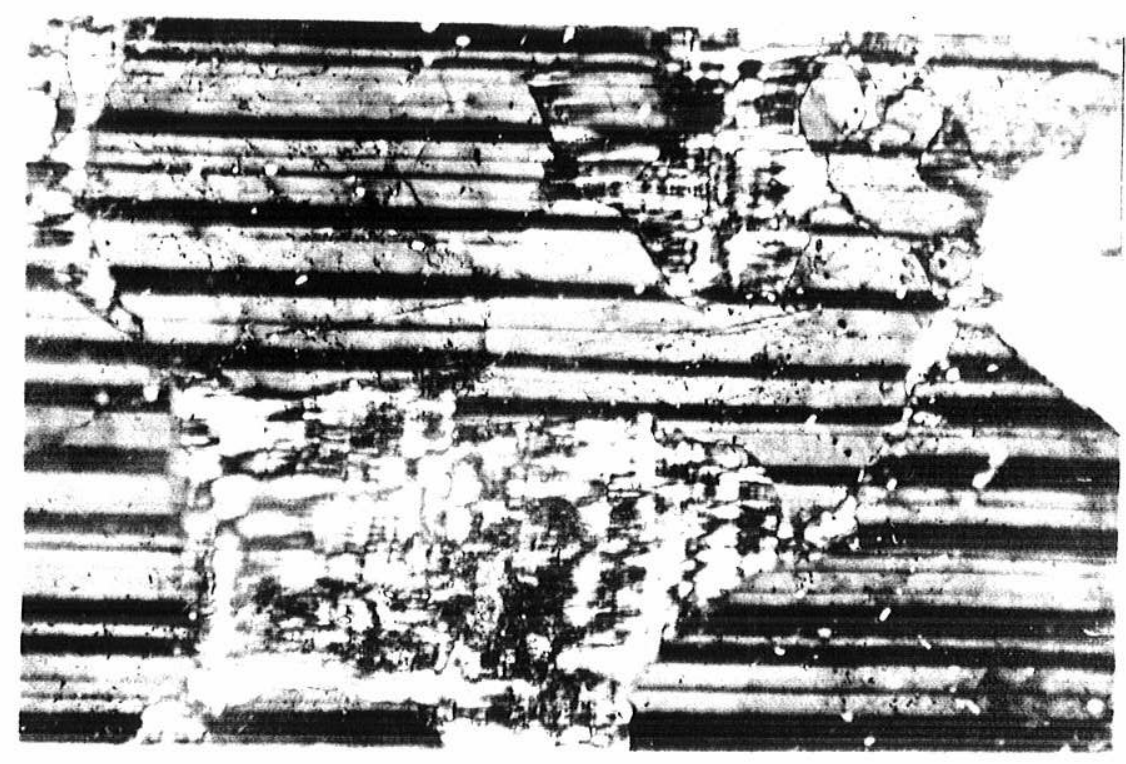

Fetomicrograrda n, 1? "Mrrocifnto crescendo dontro de poriroblasto de plagiocifisio. infibolito, no contato com eranito. nícois x. Aumento 160 vôres. 


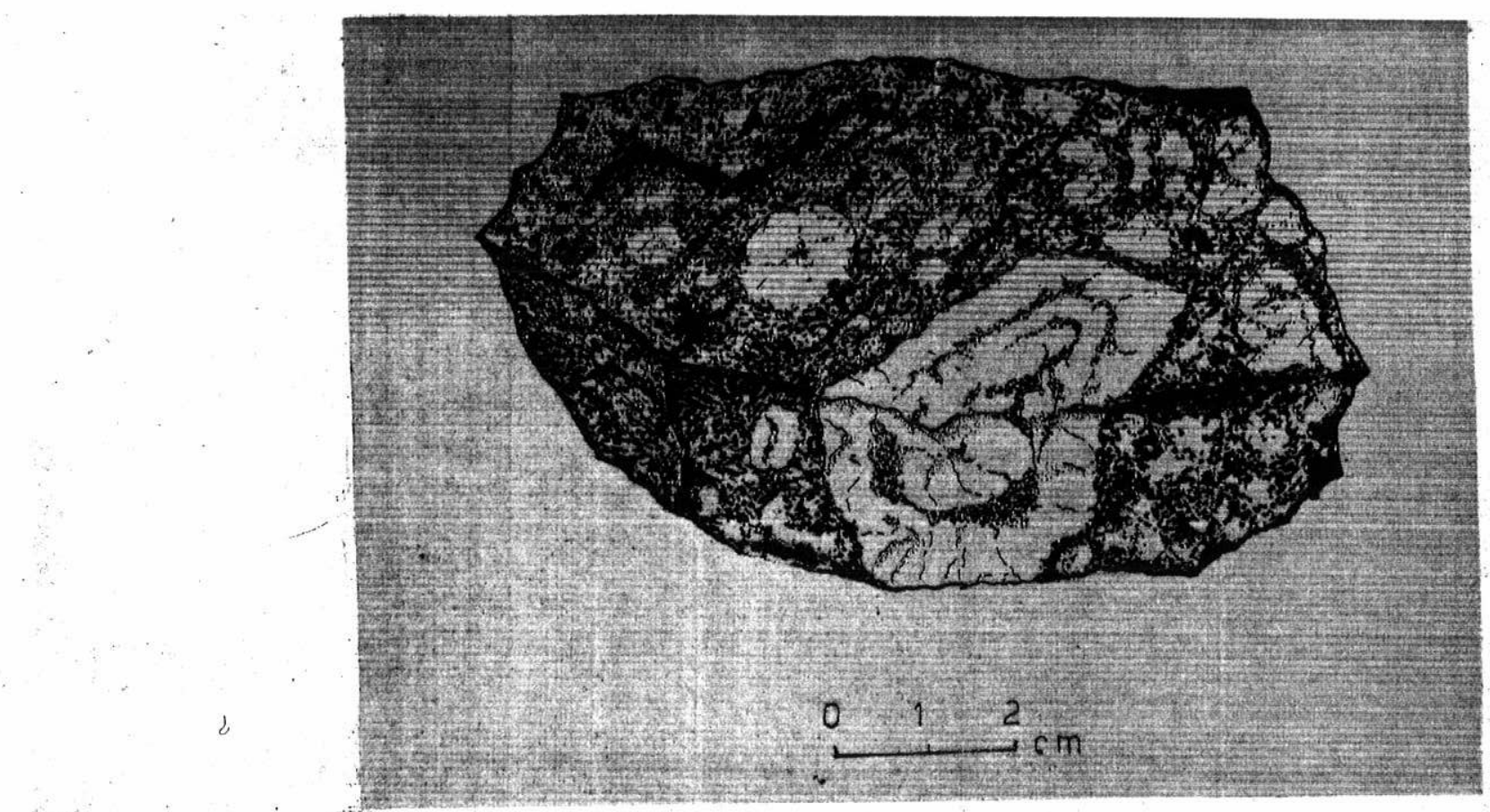

\section{HF. Af 25 - Granito com porfiroblastos de miterom olinte. As inelugóe de biotita, no derosifnis, estäo paraleles de fo-

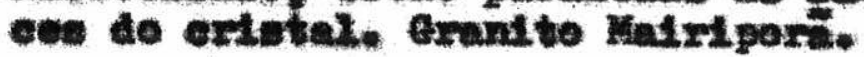

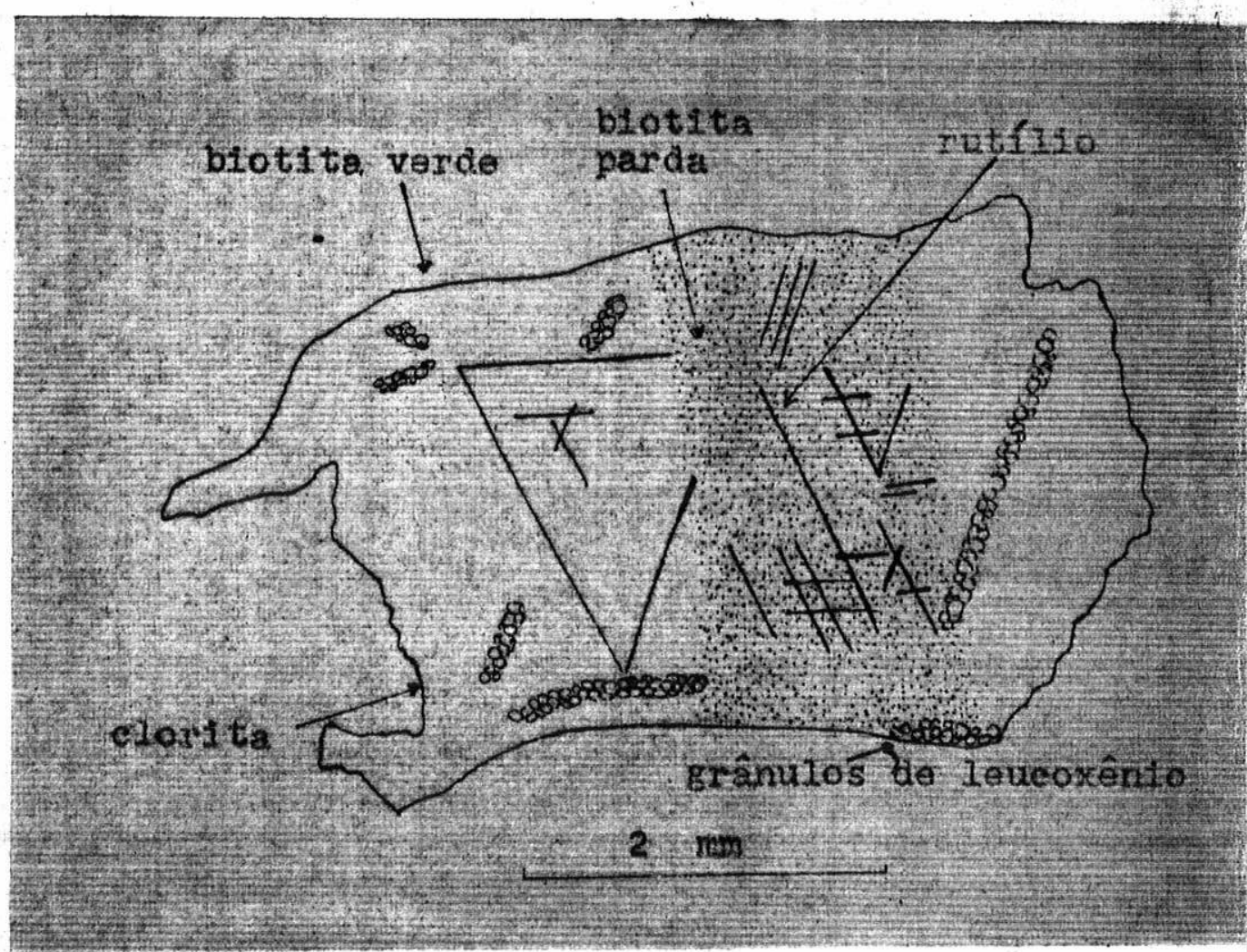

Fig. n. 26 - Blotit ta altoragāo para elorita. 


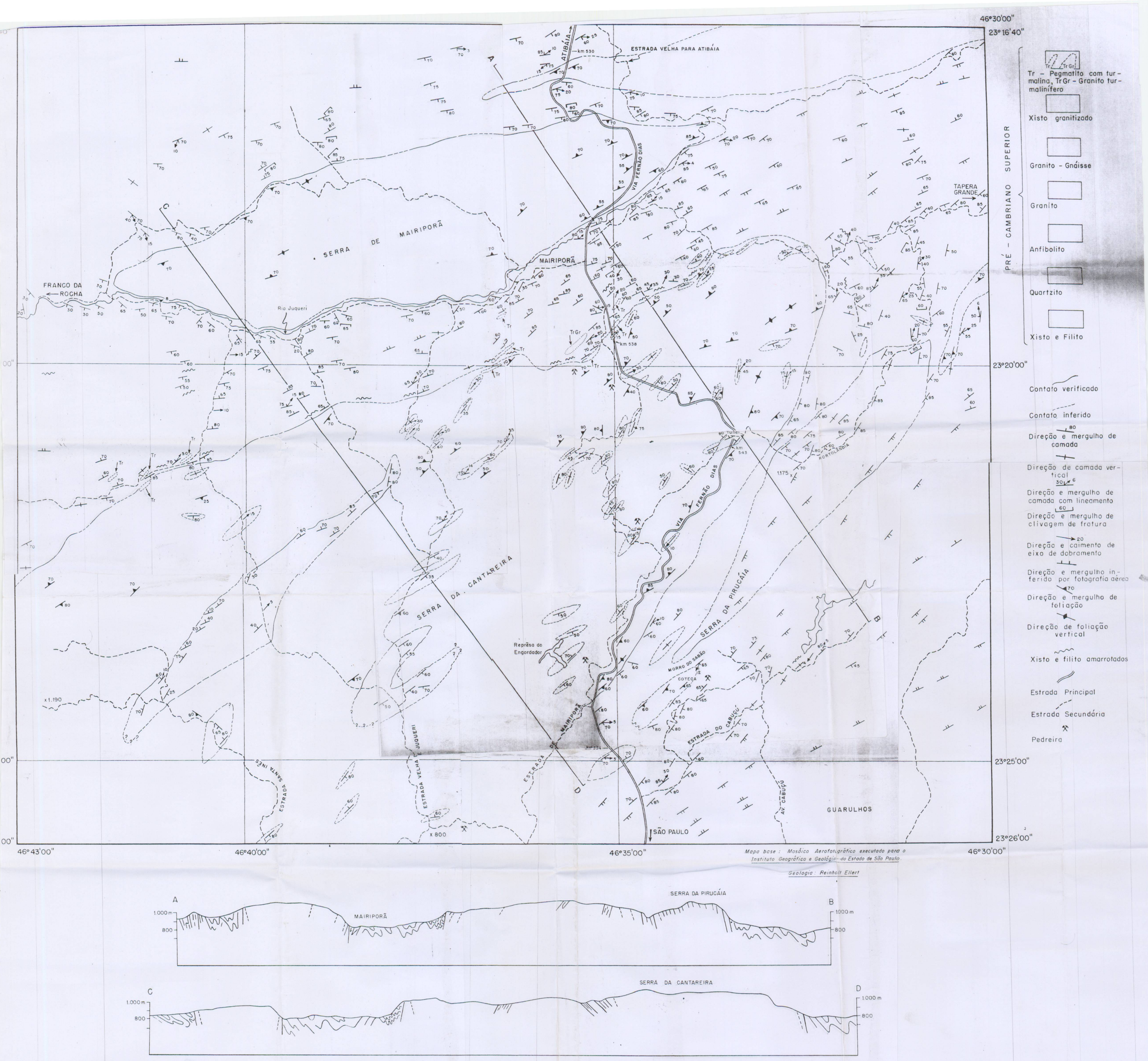

